\title{
Aplicações Distribuídas em Windows 95 Apoiadas por Ferramenta de Geração Automática de Stubs
}

\author{
Mário Antonio Meireles Teixeira
}

São Carlos (SP)

1997 


\title{
Aplicações Distribuídas em Windows 95 Apoiadas por Ferramenta de Geração Automática de Stubs
}

\author{
Mário Antonio Meireles Teixeira
}

Orientador

Prof. Dr. Marcos José Santana

Dissertação apresentada ao Instituto de Ciências Matemáticas de São Carlos, da Universidade de São Paulo, como parte dos requisitos para obtenção do título de Mestre na Área de Ciências de Computação e Matemática Computacional.

Área de Concentração:

Sistemas Distribuídos e Programação Concorrente

São Carlos (SP)

1997 
Dedico este trabalho a meu avô Mário que me soube sempre mostrar o valor do conhecimento e tem sido uma fonte de constante inspiração. 
Desdobra tuas asas de cores suaves, Adeja no espaço, procura o teu Deus: $O$ aroma das flores, e o canto das aves E o que há de mais puro se perde nos céus.

Gonçalves Dias, 1850 


\section{Agradecimentos}

A meu orientador, Prof. Marcos Santana, pelas orientações prestadas, pela confiança em meu trabalho demonstrada desde o início e pelas muitas conversas que mantivemos ao longo deste período.

A Profa. Regina Santana que sempre esteve disponível para trocar idéias, tirar dúvidas e fornecer orientações precisas.

Aos amigos Flávio, Rita, Paulo (e também Simone e Felipe), Sarita, Laís (e seus gatinhos), Márcio, Renato, Rejane, Luciano, Boca, Roberta, Renata, Célia e todos os que formam a comunidade do LaSD.

Aos amigos de Presidente Prudente Shiro, Robson, Rogério, Ronaldo, Sílvio e Milton, pelos muitos e agradáveis momentos que compartilhamos enquanto estive em São Carlos.

Aos amigos Marisa, Rejane, Júlio, João, Ciro, Teruo, Rogério (Mouro, Dei Santi e Florian), pelos bons momentos que passamos ao longo desse tempo.

A Beth, Laura e Marília, da Secretaria, a Jaques, da xerox, às bibliotecárias e a todos os funcionários do Instituto.

Aos colegas e funcionários do Departamento de Informática da UFMA, que, durante esse tempo, souberam compreender as minhas ausências e me proporcionaram um agradável ambiente de trabalho. Em especial aos professores Rubens de Oliveira e Jorge Caracas, que, enquanto estive longe, foram meus "advogados" em qualquer problema que surgisse.

À Pró-Reitoria de Pós-Graduação da UFMA e à CAPES, pelo suporte financeiro dado a este projeto.

E, especialmente, a minha mãe Mimi, meu pai Nazareno, minha tia Ana Maria, meu irmão Jorge e todos da minha família que sempre estiveram a meu lado, dando-me o apoio e incentivo necessários para buscar novos caminhos. 


\section{Sumário}

Lista de Figuras ……................................................................................. viii

Resumo

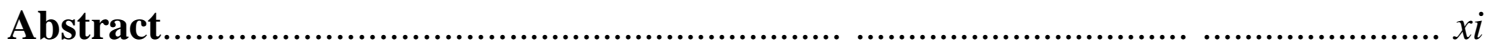

Capítulo 1 - Introdução ………………………………..................................... . .

\section{Capítulo 2 - Sistemas Distribuídos}

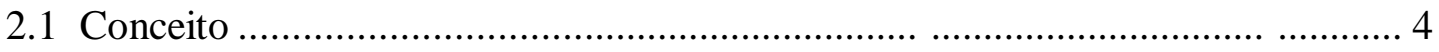

2.2 Características de um Sistema Distribuído ......................................................... 5

2.3 Modelos Arquiteturais............................................................................. 9

2.3.1 Modelo Estações de Trabalho/Servidores ............................................... 9

2.3.2 Modelo Banco de Processadores ...................................................... 10

2.3.3 Modelo baseado em Minicomputadores .................................................... 11

2.4 Dificuldades na Construção e Gerenciamento .................................................... 12

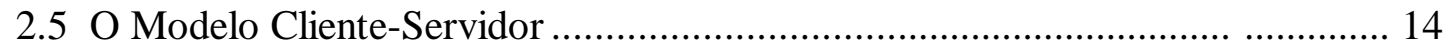

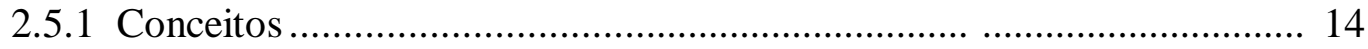

2.5.2 Vantagens e Desvantagens................................................................. 15

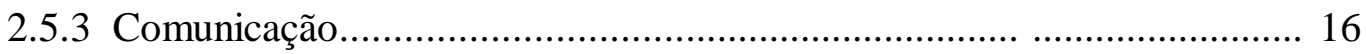

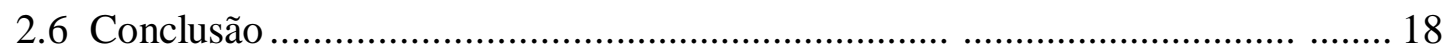

\section{Capítulo 3 - Remote Procedure Calls}

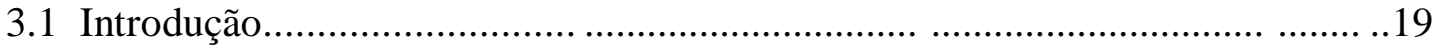

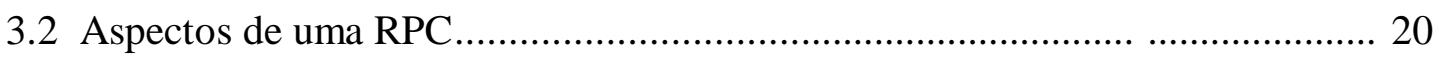

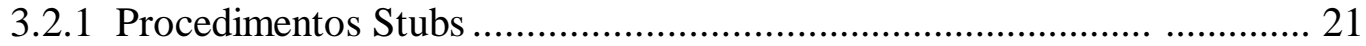

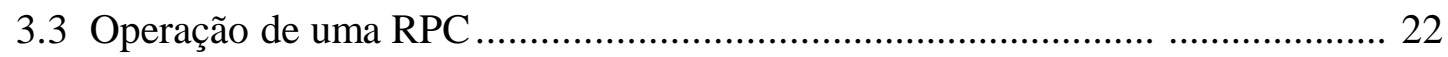

3.4 Passagem de Parâmetros ……………………........................................... 23

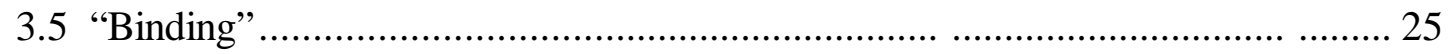

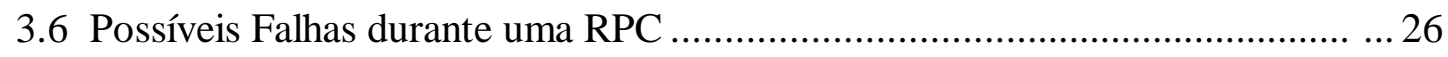

3.6.1 Cliente não consegue localizar o Servidor.............................................. 27 
3.6.2 Perda de Mensagens de Solicitação de Serviços ..................................... 27

3.6.3 Perda de Mensagens de Resposta ...................................................... 27

3.6.4 Crash do Servidor ........................................................................ 28

3.6.5 Crash do Cliente....................................................................... 28

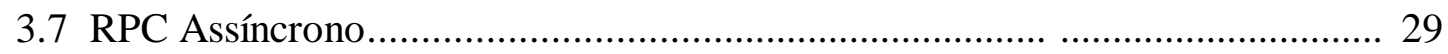

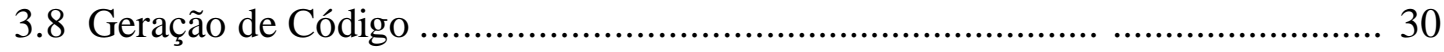

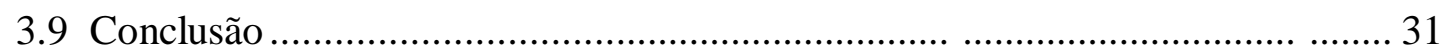

\section{Capítulo 4 - Aplicações Distribuídas Baseadas em RPCs}

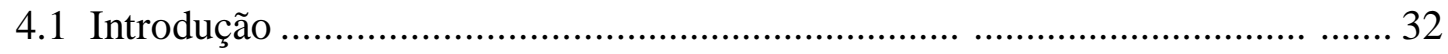

4.2 Construção de Aplicações Distribuídas........................................................ 33

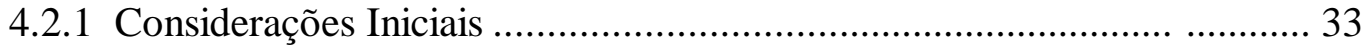

4.2.2 Desenvolvimento das Aplicações .................................................... 34

4.2.3 Subdivisão das Aplicações ................................................................ 36

4.3 O Ambiente Sun.................................................................................... 36

4.3.1 Uma Aplicação Exemplo ........................................................... 38

4.3.2 Considerações Finais ........................................................................ 39

$4.4 \mathrm{O}$ Ambiente MS-DOS ........................................................................... 40

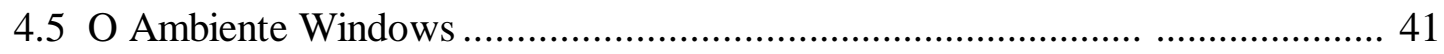

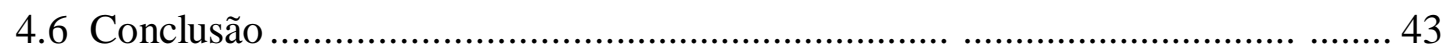

\section{Capítulo 5 - ORPCw95: Análise e Desenvolvimento}

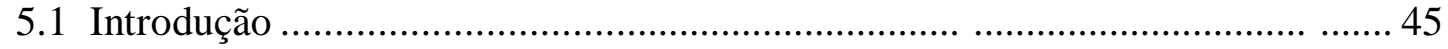

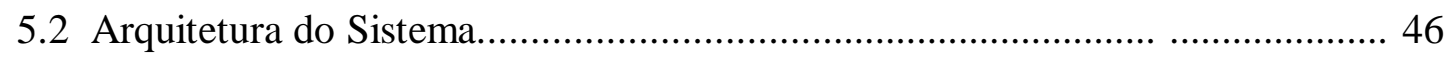

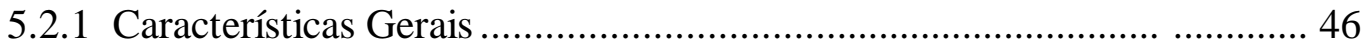

5.3 A Geração Automática dos Stubs ........................................................... 47

5.3.1 Estrutura do Gerador .................................................................. 49

5.4 A Biblioteca RPC .............................................................................. 51

5.4.1 Método Utilizado na Análise ........................................................ 51

5.4.2 Visão Geral da Biblioteca ........................................................... 52

5.4.3 A Classe RPCCall......................................................................... 53

5.4.4 A Classe RPCEnlace ................................................................... 54

5.4.5 A Classe RPCEnlaceCliente ......................................................... 55

5.4.6 A Classe RPCEnlaceServiço ........................................................ 56

5.4.7 A Classe RPCEnlaceINet............................................................ 57

5.4 .8 A Classe RPCErro ................................................................... 59 


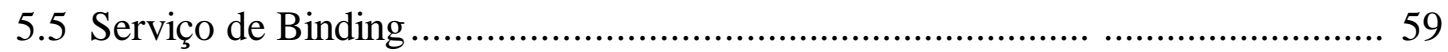

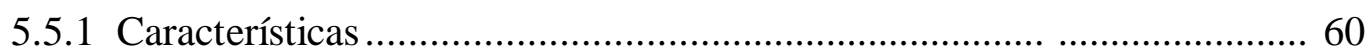

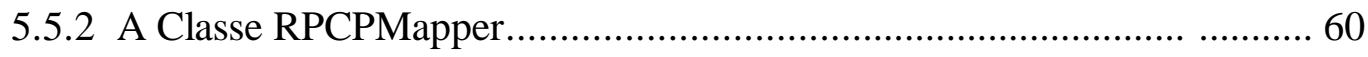

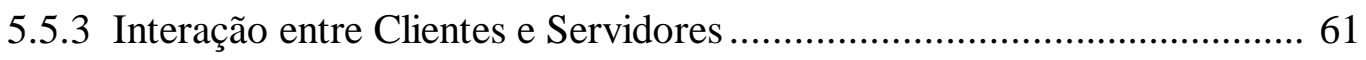

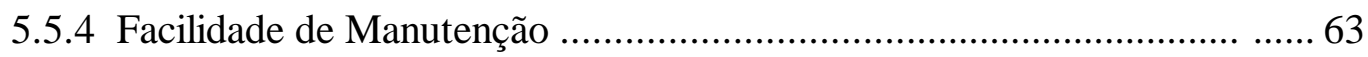

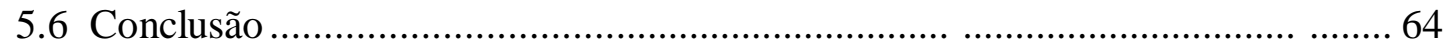

\section{Capítulo 6 - ORPCw95: Desenvolvimento de Aplicações}

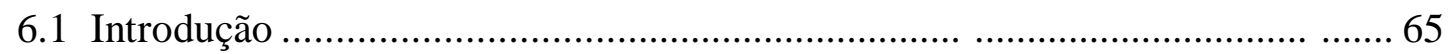

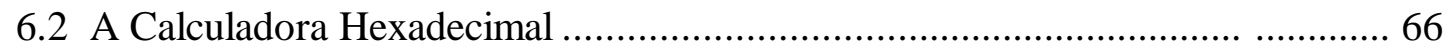

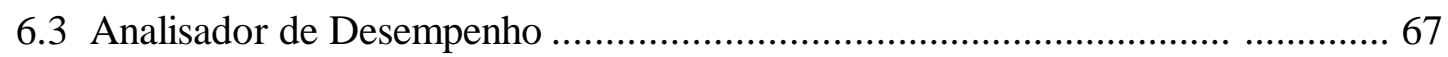

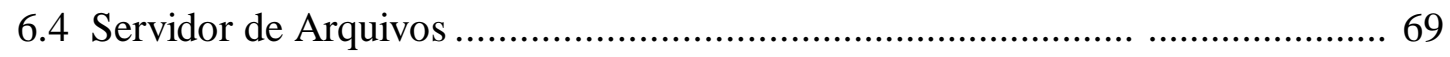

6.5 Desenvolvimento de Aplicações com ORPCw95 ………................................. 72

6.5.1 Programa Mínimo no Windows 95 ...................................................... 73

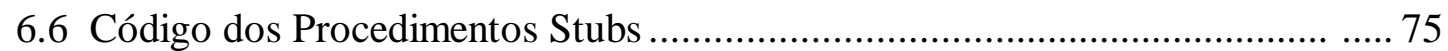

6.7 Avaliação de Desempenho da Ferramenta...................................................... 79

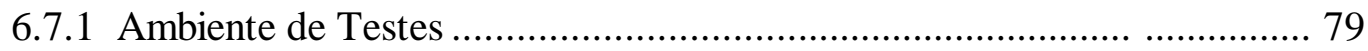

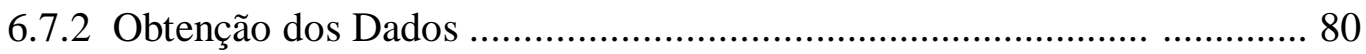

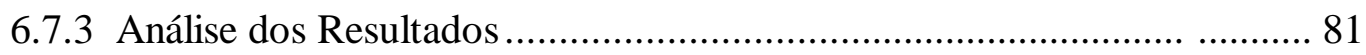

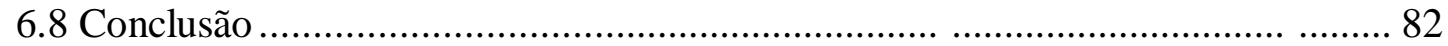

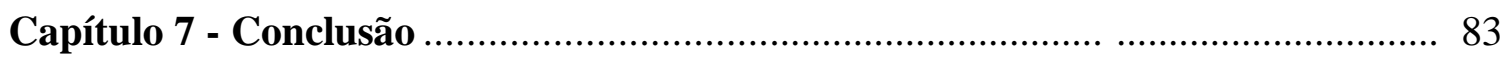

Referências Bibliográficas …………………………….................................. 86

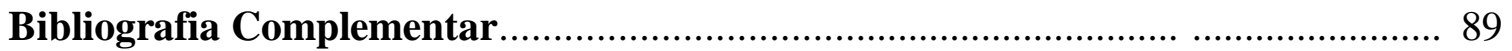

Apêndice A - Formalização da Linguagem de Especificação de Interfaces ..................... 90

Apêndice B - ORPCw95: Níveis de Classe-\&-Objeto e Estrutura ................................... 92

Apêndice C - ORPCw95: Códigos de Erro ……………………………………...... .. 93 


\section{Lista de Figuras}

Figura 2.1 - Modelo Estações de Trabalho/Servidores.................................................. 10

Figura 2.2 - Modelo Banco de Processadores........................................................... 11

Figura 2.3 - A diversidade dos componentes de um sistema distribuído ........................ 13

Figura 2.4 - A Comunicação no Modelo Cliente-Servidor ............................................. 17

Figura 3.1 - Operação de uma Remote Procedure Call .............................................. 22

Figura 3.2 - (a) Situação normal, (b) Crash depois de executar,

(c) Crash antes de executar...................................................................... 29

Figura 4.1 - O Relacionamento entre as aplicações, os stubs e a Biblioteca RPC........... 35

Figura 4.2 - Arquivos envolvidos na geração de um programa Sun RPC ..................... 39

Figura 4.3 - Estrutura do Gerador de Stubs.......................................................... .41

Figura 5.1 - Relacionamento Aplicações x ORPCw95 x OSI ......................................... 48

Figura 5.2 - Diagrama do Gerador de Stubs (ORPCw95) ........................................... 49

Figura 5.3 - Exemplo de especificação de interface...................................................... 50

Figura 5.4 - Especificação da classe RPCCall ............................................................... 53

Figura 5.5 - Especificação da classe RPCEnlace .......................................................... 54

Figura 5.6 - Especificação da classe RPCEnlaceCliente ................................................ 55

Figura 5.7 - Formato das mensagens RPC ……………........................................... 56 
Figura 5.8 - Especificação da classe RPCEnlaceServiço 57

Figura 5.9 - Especificação da classe RPCEnlaceINet ................................................. 58

Figura 5.10 - Especificação da classe RPCErro ........................................................ 59

Figura 5.11 - A lista encadeada mantida pelo Binder ................................................. 61

Figura 5.12 - Especificação da classe RPCPMapper ................................................... 61

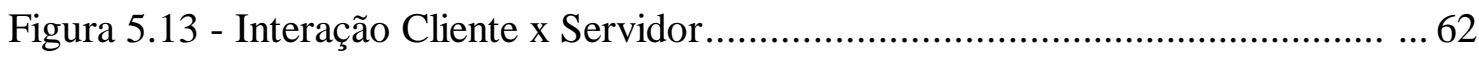

Figura 5.14 - Formato das mensagens enviadas ao Binder .......................................... 63

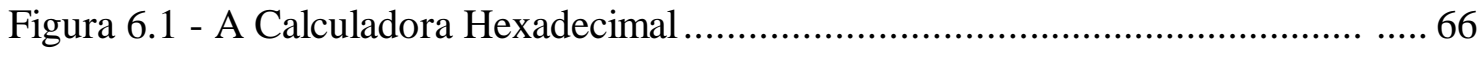

Figura 6.2 - Especificação da interface da Calculadora .............................................. 67

Figura 6.3 - Funcionamento do Analisador de Desempenho ............................................ 68

Figura 6.4 - Especificação da interface do Analisador de Desempenho ......................... 69

Figura 6.5 - Arquitetura do Serviço de Arquivos.......................................................... 70

Figura 6.6 - Exemplo de aplicação cliente para o Servidor de Arquivos .........................71

Figura 6.7 - Especificação da interface do Servidor de Arquivos ................................... 71

Figura 6.8 - Arquivo de cabeçalho para o Servidor de Arquivos ................................... 76

Figura 6.9 - Trecho do stub cliente para o Servidor de Arquivos ................................... 77

Figura 6.10 - Trecho do stub servidor para o Servidor de Arquivos.............................. 78 


\section{Resumo}

Este trabalho apresenta uma ferramenta de apoio ao desenvolvimento de aplicações distribuídas, baseadas em RPCs, para o ambiente Windows 95. Discute, ainda, algumas aplicações construídas para validar o sistema, as quais seguem o paradigma cliente-servidor. É feita uma revisão bibliográfica dos assuntos mais relevantes relacionados ao tema e apresentados os detalhes de implementação da ferramenta. Esta foi implementada com técnicas de orientação a objetos, sendo composta por um Gerador Automático de Stubs e uma Biblioteca RPC, além de possibilitar a utilização de um Serviço de Binding. As aplicações construídas procuram explorar as potencialidades da ferramenta, sendo fornecidas também orientações gerais para o desenvolvimento de aplicações distribuídas no ambiente Windows 95. 


\section{Abstract}

This work presents a tool to support the development of RPC-based distributed applications in the Windows 95 environment. It also discusses some applications built to validate the system, which follow the client-server model. A theoretical review of the most relevant topics related to the field is done and the tool's implementation details are presented. This tool was implemented with object-oriented techniques and comprises an automatic Stub Generator and an RPC Library, together with a Binding Service. The distributed applications that were built try to explore the tool's full potential. General guidelines regarding the development of distributed applications for the Windows 95 environment are also provided. 


\section{1}

\section{Introdução}

Os Sistemas Computacionais Distribuídos, há mais de uma década, já deixaram de ser apenas uma promessa, não estando mais restritos a pesquisas realizadas nos meios acadêmicos. Hoje, com um maior ou menor grau de conformidade em relação àquilo que se considera "distribuído", já há vários exemplos bem-sucedidos de implementações e o número e a diversidade das aplicações distribuídas não pára de crescer, abrangendo ambientes tão diversos como o meio acadêmico, comércio, indústria e residências.

Contudo, a construção de aplicações distribuídas impõe novos desafios aos programadores, pela diversidade dos ambientes computacionais envolvidos, pela necessidade de troca de mensagens através da rede e devido à própria compreensão do que vem a ser uma aplicação distribuída. Sendo assim, é importante que existam boas ferramentas de apoio à construção dessas aplicações, procurando-se tornar seu trabalho de implementação semelhante ao das aplicações centralizadas, cuja técnica já é amplamente conhecida e dominada pela maioria dos usuários (programadores).

Analisando-se o cenário das implementações bem-sucedidas de aplicações distribuídas, vê-se que o modelo dominante é o paradigma cliente-servidor, em que os usuários interagem com aplicações que podem ser clientes de outros serviços disponíveis no sistema e cada serviço provê uma série de funções que podem ser invocadas pelos clientes. A comunicação entre clientes e servidores se dá por meio de um mecanismo de passagem de mensagens, particularmente através do mecanismo de RPCs (Remote Procedure Calls), que tenta esconder dos programadores a complexidade da comunicação através da rede e a diversidade dos ambientes computacionais envolvidos, procurando 
fazer com que a chamada remota seja o mais semelhante possível às chamadas locais convencionais.

O núcleo de um sistema de RPC é o gerador de stubs, que automatiza a criação dos módulos de comunicação entre cliente e servidor, devendo esta ser o mais transparente possível aos usuários do sistema, por ser justamente neste ponto que reside a maior dificuldade da RPC e ser também um dos fatores de distanciamento entre as chamadas remotas e as locais. Assim, a existência de um gerador automático de stubs é sempre atrativa.

Tais geradores estão disponíveis em diversos ambientes, com graus de transparência variados, como, por exemplo, UNIX (SUN rpcgen) [Sun90] e MS-DOS [Nas95], sendo de grande interesse tê-los também para Windows, particularmente para o Windows 95, a fim de que se possa implementar aplicações distribuídas nesse ambiente.

No Capítulo 2 desta dissertação, faz-se uma revisão dos conceitos básicos relacionados à área de Sistemas Distribuídos e de suas características principais, tecendose comparações com outras soluções adotadas. Também se abordam os principais modelos arquiteturais existentes e o paradigma cliente-servidor.

No Capítulo 3, chega-se ao assunto propriamente dito deste projeto de Mestrado, que são as chamadas a procedimentos remotos. Aqui, são analisados seus aspectos principais, peculiaridades em relação às chamadas locais, tratamento de falhas, localização dos servidores pelos clientes, interconexões assíncronas, dentre outros, finalizando-se com uma comparação entre a geração de código automática e a manual.

Passa-se, então, para o Capítulo 4, em que se discutem os desafios inerentes à construção das aplicações distribuídas, fornecendo-se algumas orientações sobre como se suceder bem nessa área. Destaca-se, ainda, a importância das RPCs como um elemento facilitador do desenvolvimento de softwares distribuídos, concluindo-se com um paralelo entre as características de RPC implementadas nos ambientes Sun, MS-DOS e Windows.

No Capítulo 5, discutem-se as principais características da ferramenta de RPCs implementada, analisando-se o Gerador de Stubs e a Biblioteca RPC, sendo abordadas suas classes e os relacionamentos entre elas. É feita, também, uma apresentação do Serviço de Binding do sistema e da forma de interação dos clientes e servidores com o mesmo.

O Capítulo 6 trata de algumas aplicações distribuídas implementadas com o uso da ferramenta. Procura-se explorar as potencialidades da mesma, sendo apresentado um esboço de programa mínimo no ambiente Windows 95, com suporte a RPCs. São abordados também detalhes da implementação do código dos procedimentos stubs e feita 
uma comparação do desempenho de aplicações distribuídas construídas com o uso da API Windows Sockets e com a ferramenta de RPCs apresentada.

Finalmente, no Capítulo 7, chega-se à conclusão da dissertação, sendo destacadas suas contribuições mais importantes e apontados caminhos para melhoramentos e trabalhos futuros. 


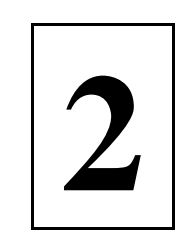

\section{Sistemas Distribuídos}

Neste capítulo, serão abordados alguns tópicos essenciais concernentes à área de sistemas distribuídos, tais como o conceito do que vem a ser um sistema desse tipo, quais são suas principais características e como elas o diferenciam de um sistema centralizado convencional. Serão vistas, também, as principais formas de organização arquitetural dos sistemas distribuídos e porque construí-los e gerenciá-los não é uma tarefa para iniciantes. Finalmente, será abordado o modelo cliente-servidor, cujos conceitos constituem a base teórica para a interação entre os componentes da maioria dos sistemas distribuídos atuais.

\subsection{Concelto}

O termo "sistema distribuído", como tantos outros no campo da Informática, tem sido usado à exaustão, para descrever desde simples sistemas operacionais de rede até complexas implementações de sistemas distribuídos reais, muitas vezes até como uma estratégia de marketing. Assim, como tantas outras expressões largamente utilizadas, corre o risco de perder seu sentido original.

É preciso então, desde já, delimitar-se bem o escopo deste termo, a fim de se ter certeza de que se está falando sobre as mesmas coisas. Uma definição bastante coerente, embora antiga, é a enunciada por Tanenbaum [Tan85] e aperfeiçoada por Mullender [Mul89], que diz que um sistema distribuído é aquele que se apresenta aos seus usuários como um sistema centralizado, mas que, na verdade, funciona em diversas CPUs independentes. Além disso, um sistema distribuído não deve ter pontos críticos de falha, 
ou seja, se um componente do mesmo quebrar, isto não deve fazer com que o sistema como um todo falhe.

Coulouris [Cou94] enfatiza que os computadores de um sistema distribuído devem estar conectados através de uma rede, caracterizando bem o fato de que estes não precisam estar localizados em uma única sala, ou mesmo próximos entre si, já que, a princípio, não há limite para a área abrangida por um sistema desse tipo. Além disso, esse autor ressalta o fato de que os computadores devem estar equipados com software de sistemas distribuídos, por ser justamente este componente que fará com que os usuários vejam o sistema como uma entidade única, integrada, embora o mesmo se encontre funcionando em computadores diferentes, situados em locais os mais diversos.

Finalmente, é importante a contribuição de Müllender [Mul89] no sentido de que um sistema distribuído não deve ter pontos críticos de falha, sendo esta característica de estabilidade uma de suas principais vantagens em relação a um sistema centralizado.

\subsection{Característlcas de um Slstema Dktrlbuído}

Nesta seção, serão abordadas algumas das características fundamentais de um sistema distribuído, indicando-se porque estas o tornam tão especial e atrativo.

Compartilhamento de Recursos. [Cou94] O termo "recurso" é bastante abrangente e, neste contexto, refere-se a qualquer entidade do sistema passível de ser compartilhada. Incluem-se aqui tanto componentes de hardware como discos, impressoras, scanners, quanto elementos como arquivos, aplicativos e outros. $\mathrm{O}$ compartilhamento de recursos é um ponto fundamental em qualquer sistema, seja ele centralizado ou distribuído. No primeiro caso, o compartilhamento é imediato, uma vez que todos os recursos estão concentrados em único local, ao qual se conectam os terminais. Já no caso distribuído, os recursos encontram-se espalhados pela rede, contidos dentro dos diversos equipamentos e o acesso a eles é gerenciado por meio de softwares servidores, que determinam quais as operações que podem ser realizadas e por quem. Portanto, gerenciar os recursos de um sistema distribuído de forma ótima não é uma tarefa trivial.

Capacidade de Expansão (Scalability) e Modularidade. [Cou94] Em um sistema centralizado, há um limite físico para o número máximo de processadores que podem ser incorporados em uma máquina, para a capacidade máxima de memória e para o número de discos. Já em um sistema distribuído, teoricamente não existe limite para o número de máquinas que podem compor o sistema, nem para a distância e diversidade das 
mesmas. Isto, com certeza, é uma característica desejável para qualquer sistema, mas complica sobremaneira o desenvolvimento do software distribuído, uma vez que este tem que continuar se comportando satisfatoriamente à medida em que o sistema cresce. Outro ponto de pressão é a rede, que pode vir a ter sua capacidade sobrepujada pelo excesso de mensagens e dados circulando na mesma. A modularidade implica que o sistema pode ser expandido gradualmente, introduzindo-se software e máquinas conforme a necessidade. Isto, de certa forma, facilita a manutenção do sistema e o isolamento de falhas.

Disponibilidade. Como já foi comentado, uma das características mais interessantes de um sistema distribuído é que a falha de um componente individual não pode fazer com que o sistema como um todo pare. Dessa forma, se uma estação de trabalho falha, os programas sendo executados nela têm que ser migrados para uma outra máquina da maneira mais transparente possível para o usuário, idealmente de forma que este nem mesmo se dê conta da falha que acabou de ocorrer. Problemas em servidores (de arquivos, mail, impressão etc.) também têm que ser tratados de forma transparente, com um outro equipamento tomando o lugar do que falhou imediatamente. A fim de garantir a disponibilidade do sistema a qualquer custo, o projeto do mesmo tem que contemplar dois aspectos: redundância (de hardware, software e dados) e algoritmos de recuperação [Cou94].

A redundância, se feita com critério e controlada, é um dos pontos mais importantes para aumentar a disponibilidade de um sistema distribuído. Isto é óbvio, pois se houver um único servidor de arquivos, por exemplo, a falha dessa máquina interromperá a operação de todo o sistema. Portanto, para os serviços mais críticos, é sempre bom ter uma máquina sobressalente, pronta para entrar em ação (é claro que, no intervalo entre as falhas, que se espera ser razoavelmente grande, essa máquina tem que ser usada para outros fins). No caso de redundância de dados e software, é preciso empregar técnicas para evitar a proliferação de inconsistências.

Entretanto, é bom sempre ter em mente que, se por um lado, a redundância ou replicação aumenta a disponibilidade dos recursos e informações, por outro lado ela vai também implicar em uma certa perda de desempenho do sistema, devendo-se analisar, portanto, quando é o momento certo de replicar.

Quanto aos algoritmos de recuperação, estes devem ser capazes de retornar o sistema a um estado correto anterior, no caso de uma falha. Têm-se desenvolvido bastante pesquisas nessa área e muita contribuição tem vindo da área de banco de dados. Aqui, entra em cena o gerenciamento de transações distribuídas [Cou94; Cap. 14, 15].

Concorrência. Em um sistema centralizado, do tipo time sharing, que possua um só processador, a concorrência dos processos é obtida através do revezamento no uso da CPU. Mesmo no caso em que exista mais de uma CPU, há um limite até mesmo físico e de projeto para o número máximo de processadores que uma máquina pode conter. Já em 
um sistema distribuído, devido à característica deste possuir várias máquinas diferentes, conectadas por uma rede, o fato de ocorrer paralelismo e concorrência é uma conseqüência natural.

Considere, por exemplo [Cou94], o caso de um usuário que submeta vários processos (programas) para execução em uma estação de trabalho. A concorrência, aqui, ocorre entre os seus próprios processos e, tomando-se a visão global do sistema, em outras estações existirão também outros processos executando, pertencentes a outros usuários, o que aumenta ainda mais o grau de paralelismo. E, o que é mais importante, processos de um usuário executando em um máquina não irão degradar o desempenho dos processos de um outro usuário em uma estação diferente (salvo, talvez, pelo uso que estes possam vir a fazer da rede), diferentemente de um sistema de tempo compartilhado, em que normalmente existe uma única CPU, barramento, memória etc. para ser compartilhados entre vários processos.

Outra oportunidade de concorrência é o fato de os serviços do sistema serem executados em diferentes servidores, o que implica dizer que as requisições de serviço por parte dos clientes são efetivamente atendidas em paralelo. Isto é particularmente interessante para serviços muito solicitados, como o acesso a arquivos, porém é necessário dotar as máquinas de um software adequado a fim de sincronizar as requisições e garantir que o paralelismo na execução das operações não venha a provocar o surgimento de inconsistências.

Assim, vê-se que, em um sistema distribuído, é bastante presente a concorrência na execução das tarefas, surgindo como uma característica natural do sistema.

Informação de Estado Compartilhado. Dado o escopo de um sistema distribuído e o número e a diversidade das estações de trabalho e a própria natureza distribuída dos dados, torna-se muito difícil obter informações globais sobre o estado do sistema. O que normalmente acontece é que determinadas regiões do mesmo possuem informações de âmbito local, que são compartilhadas sob demanda. Como exemplo, tem-se o caso do roteamento em uma internetwork [Tan94]: cada nó roteador contém informações sobre qual o melhor caminho para chegar a um determinado local, a partir dele. Assim, se chega um pacote para aquele destino, este é enviado para o nó indicado na tabela de roteamento, de lá para outro ponto e assim por diante. Não há, em nenhum local, um elemento coordenador que contenha as informações de roteamento para toda a rede, pois isto seria impraticável devido ao enorme volume de dados que teria que ser processado. Esta situação é a que normalmente se encontra em sistemas distribuídos e, se por um lado é vantajosa, porque não dá a nenhum equipamento a tarefa de saber tudo sobre determinado aspecto do sistema (o que criaria pontos críticos de falha), por outro lado torna muito difícil obter informações sobre certos pontos fundamentais para o gerenciamento do sistema, como a carga de trabalho nas estações do mesmo, a utilização da rede, dentre outros. 
Transparência. Transparência, neste contexto, significa esconder dos usuários e programadores a separação inerente aos componentes de um sistema distribuído, de modo que estes o percebam como um todo integrado e não como um conjunto de elementos independentes [Cou94]. A separação dos componentes do sistema é que permite, por exemplo, o paralelismo real na execução dos programas, como já foi comentado, o isolamento de falhas em regiões específicas do sistema e sua recuperação sem afetar outros pontos do mesmo, o monitoramento dos canais de comunicação com o objetivo de empregar políticas de segurança, e também garante a capacidade de crescimento ou redimensionamento do sistema à medida em que isto se faz necessário. Entretanto, é de suma importância, em um sistema distribuído, que essa dispersão dos seus componentes seja escondida dos usuários através do uso de softwares apropriados de gerenciamento. A seguir, serão comentados alguns tipos de transparência que podem ser encontrados em um sistema.

A Transparência de Acesso significa que as operações utilizadas para se ter acesso a um objeto ou recurso (arquivos, dispositivos, processos) são as mesmas, independentemente do fato de este se encontrar na mesma máquina onde foi solicitada a operação ou em um equipamento remoto. Outro aspecto que auxilia no aumento da transparência é o fato de que o nome de um objeto não deve conter nenhuma informação acerca de sua localização, de modo que este possa ser invocado sem conhecimento de seu lugar físico. Isso leva a dois tipos de transparência: a de Localização (por motivos óbvios) [Wal89] e a de Migração, que implica que um objeto pode ser movido de um lugar para outro do sistema (leia-se rede) sem afetar a maneira como os usuários ou programas o referenciam. Se um sistema possui transparência de acesso e localização dizse que ele apresenta a chamada Transparência de Rede, que facilita sobremaneira a utilização dos recursos do sistema distribuído, devendo ser, portanto, um dos principais objetivos a serem perseguidos pelos projetistas do mesmo.

A Transparência de Concorrência permite que diversos processos tenham acesso aos mesmos objetos concorrentemente sem que um afete o trabalho do outro e sem que ocorra uma degradação significativa no desempenho. A Transparência de Replicação garante que diferentes réplicas de um objeto podem ser mantidas pelo sistema a fim de aumentar sua confiabilidade e melhorar seu desempenho sem que os usuários se dêem conta disso. A transparência em relação a Falhas significa que estas serão confinadas ao local onde ocorreram, na medida do possível, a fim de que os usuários não diretamente afetados possam continuar trabalhando normalmente, apesar dos erros ocorridos no hardware ou software. Outro tipo interessante é a Transparência de Desempenho, que permite que o sistema se reconfigure (por exemplo, através da migração de processos de uma máquina para outra) a fim de continuar oferecendo a mesma qualidade de serviço aos seus usuários, apesar da variação de sua carga de trabalho. Finalmente, a Transparência de Expansão (Scaling) garante que o sistema distribuído possa se expandir sem alterar a sua estrutura básica e sem provocar a necessidade de se rescrever os programas existentes. 
Para concluir, vale acrescentar que não há, atualmente (pelo menos no âmbito desta revisão bibliográfica), nenhum sistema que apresente todas estas formas de transparência. Na verdade, elas são apenas diretrizes que devem nortear o projeto de qualquer sistema distribuído, a fim de garantir uma maior homogeneidade e coerência no acesso a seus objetos, por parte dos usuários e programas.

\subsection{Modelos Arqulteturals}

Um modelo arquitetural de um sistema define quais são os diversos componentes do mesmo e como estes estão organizados. No campo dos sistemas distribuídos, existem três ou quatro modelos diferentes já experimentados, sendo que um deles vem se firmando como o padrão de fato para a organização desse tipo de sistemas e os outros são encontrados mais em nível de pesquisa.

\subsubsection{Modelo Estaçöes de Trabalho/Servidores}

Constitui-se em um sistema do tipo fracamente acoplado, no sentido de que a memória dos computadores é distribuída, sendo que cada usuário possui uma estação de trabalho, com capacidade de processamento autônoma e tem acesso aos recursos e dados compartilhados através da rede local, os quais estão sob a guarda dos servidores (Fig. 2.1). Uma característica desse tipo de sistemas é que a maior parte do serviço se dá localmente, na própria estação de trabalho de cada usuário, o que evita a necessidade de haver um centro de processamento que freqüentemente se torna um gargalo no sistema, além de afetar a confiabilidade do mesmo; porém sabe-se que os servidores, se não forem bem projetados, também podem se tornar pontos de contenção.

Esse tipo de organização iniciou-se com o sistema conhecido como Xerox PARC, passando por outros como o Cambridge Distributed Computing System, o Sistema Trice e, atualmente, as redes de estações de trabalho Sun. A interconexão dos computadores é feita através de redes locais e o sistema é geralmente baseado em uma organização do tipo cliente-servidor, sendo utilizado, como forma de comunicação, um mecanismo de RPCs [Cou94]. 


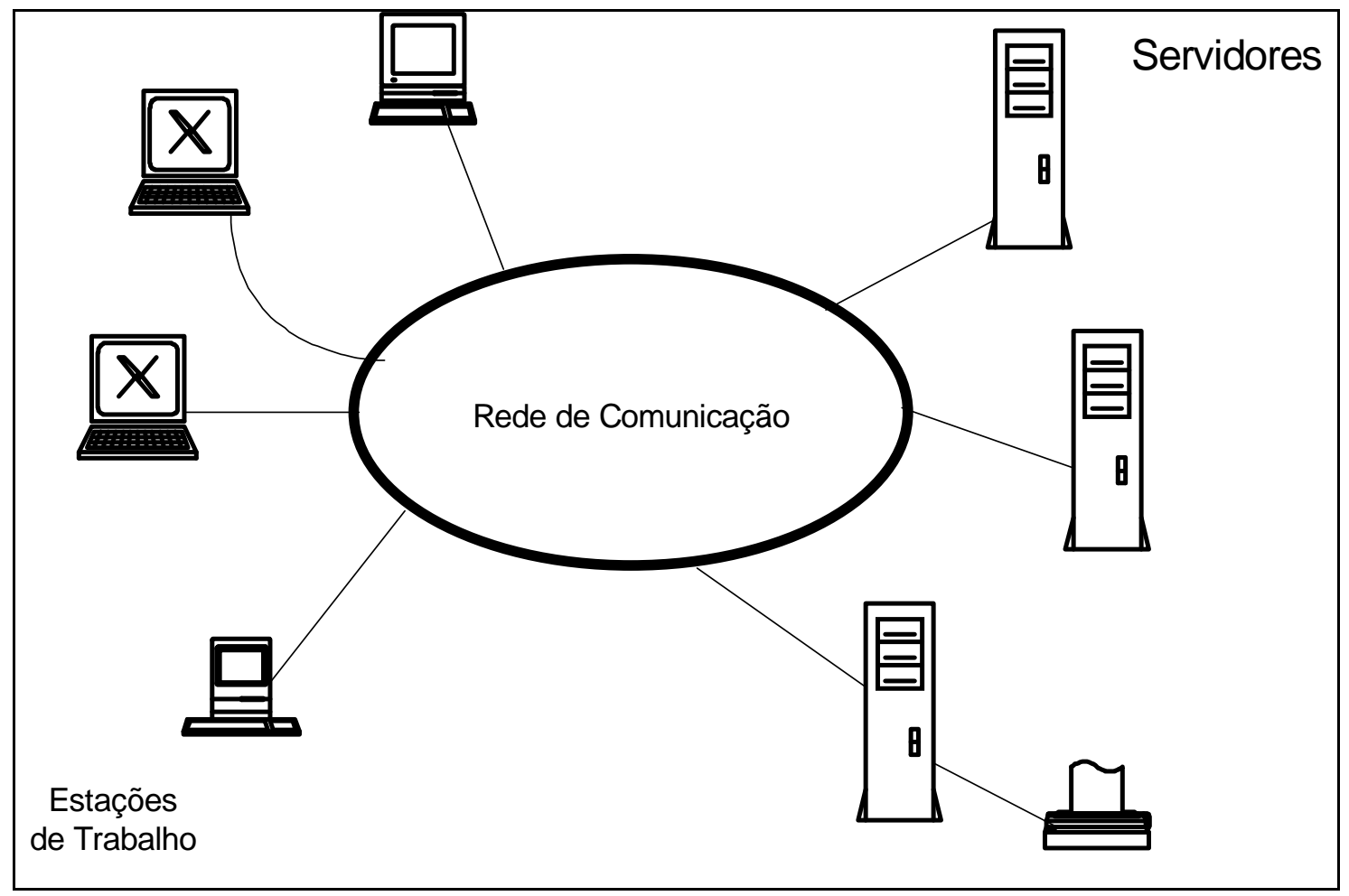

Fig. 2.1 - Modelo Estações de Trabalho/Servidores

\subsubsection{Modelo Banco de Processadores}

Neste modelo, existe um conjunto ou banco de processadores gerenciado pelo sistema como se fosse um serviço de processadores (Fig. 2.2). Os usuários trabalham em terminais ligados ao banco por meio de concentradores de terminais e, quando vão iniciar alguma tarefa, abrem uma sessão de trabalho e solicitam ao sistema um ou mais processadores, que são alocados conforme a complexidade da mesma. Ao final do serviço, os processadores são liberados e voltam ao banco. O principal exemplo desse modelo é o Sistema Amoeba [Tan92].

A maior vantagem dessa organização em relação ao modelo de estações de trabalho/servidores é que aqui não se desperdiça a capacidade de processamento das estações, pois, no primeiro modelo, na maior parte do tempo os usuários usam apenas uma pequena parcela de todo o poder de processamento que uma estação de trabalho pode lhes proporcionar. Utilizando-se o banco de processadores, dá-se o contrário, pois o poder é colocado justamente onde ele se faz mais necessário. Por outro lado, é preciso gerenciar bem o banco de processadores, principalmente a malha de interconexão deste 
com o resto do sistema, a fim de que ele não se torne um gargalo, nem um ponto crítico de falha do mesmo.

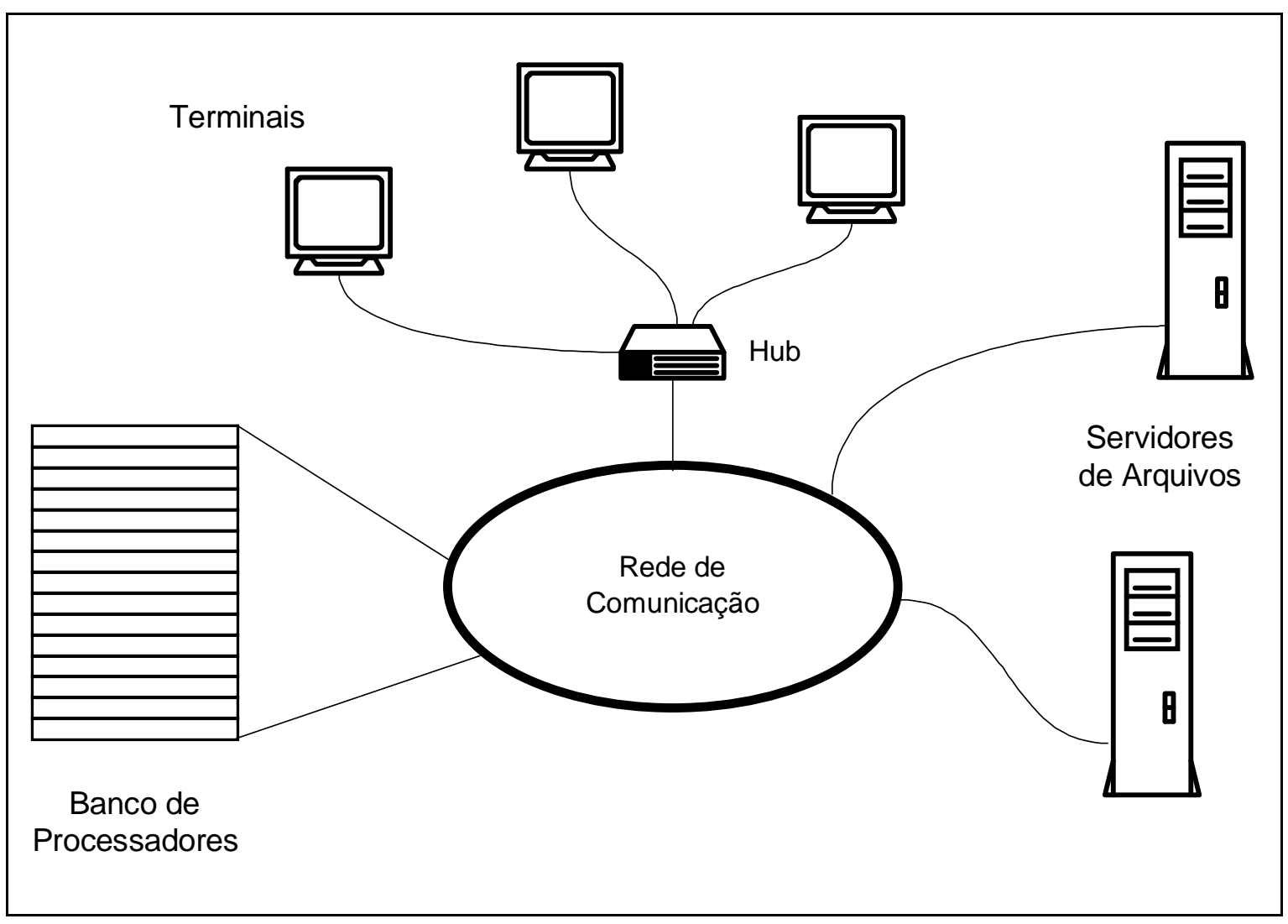

Fig. 2.2 - Modelo Banco de Processadores

\subsubsection{Modelo baseado em Minicomputadores}

Este modelo geralmente surge como uma evolução de uma instalação de minicomputadores, na verdade como uma tentativa de aproveitar o investimento já feito pela empresa ou instituição. Aqui, tem-se um conjunto não muito grande de minicomputadores interligados por rede local, que proporcionam um ambiente multiusuário a seus clientes, que podem ter acesso tanto à máquina à qual estão ligados diretamente quanto fazer acesso remoto a outras máquinas e seus periféricos através da rede. A tendência aqui é acabar evoluindo para um modelo de estações de trabalho/servidores, talvez mantendo os minicomputadores apenas como repositório de dados [U1193].

Além dos modelos já descritos, existem também os chamados Modelos Híbridos, ou seja, estações de trabalho e servidores combinados com banco de processadores ou 
com minicomputadores, como foi comentado acima. $\mathrm{O}$ objetivo é tentar reunir as melhores qualidades de uma e outra forma de organização e também preservar investimentos anteriores feitos em equipamentos e treinamento de pessoal.

\subsection{Diflculdades na Construçáo e Gerenclamento}

Pelo que já foi discutido, percebe-se que um sistema distribuído não é algo trivial de se construir e manter. Embora já se tenha mais de uma década de pesquisa na área e já tenha havido bastante progresso, ainda há um bom caminho a percorrer até que se chegue ao sistema perfeito, totalmente transparente, com desempenho aceitável sob quaisquer condições e que se mantenha em funcionamento por mais sérios que sejam os erros ocorridos.

Nesta seção, serão discutidas as razões da complexidade inerente ao projeto, construção e gerenciamento de sistemas distribuídos.

Diversidade. Os elementos que compõem um sistema distribuído são muito diversos (Fig. 2.3), sejam eles estações de trabalho, placas de rede, cabos de interconexão ou softwares de gerenciamento. Para repetir uma máxima já consagrada, muitas vezes, coisas conhecidas, que funcionam muito bem sozinhas ou em um ambiente homogêneo, apresentam problemas inesperados quando conectadas em um ambiente tão heterogêneo como é um sistema do tipo distribuído [Mul89]. E aqui, ao contrário dos sistemas do tipo time sharing tradicionais, não há um fornecedor único a quem recorrer [Ul193]. Na verdade, há vários, sem nenhuma ligação entre si além de um cliente comum e é este último elemento que tem que resolver os problemas que surgem e manter o sistema funcionando.

Interconexão. A interconexão de máquinas pode trazer problemas de incompatibilidade, de conectores e outros, como se sabe, porém os maiores problemas surgem na interconexão a nível de sistema, por exemplo para a comunicação e o acesso a arquivos entre sistemas UNIX de famílias diferentes [Mul89]. Outro problema pode ocorrer na troca de mensagens de correio eletrônico. Porém, como já foi comentado, esta região de interconexão é justamente o "buraco negro" sobre o qual nenhum dos fornecedores envolvidos quer opinar [U1193].

Propagação e Rastreamento de Erros. Nos sistemas centralizados de "antigamente", encontrar um erro era relativamente fácil se comparado aos sistemas distribuídos. Afinal, excluindo-se as linhas de comunicação até os terminais "burros", o erro só poderia estar naquela máquina central, já que todo o processamento e recursos se 
encontravam em torno dela. É claro que a situação está sendo um pouco simplificada, pois, de qualquer forma, nunca foi tão simples assim. Entretanto, em um ambiente distribuído, dada a diversidade dos elementos envolvidos e considerando-se que cada estação é autônoma no que se refere a sua capacidade de processamento, fica difícil encontrar exatamente qual o ponto em que se deu o erro. Por exemplo, se uma mensagem enviada a uma aplicação em um outro computador não foi respondida, como saber com exatidão o que ocorreu? $\mathrm{O}$ equipamento de destino não está funcionando? A conexão até ele está interrompida? A solicitação se perdeu na rede ou será que foi a resposta a ela? Ou talvez a estação de destino simplesmente estava ocupada demais para responder? Essas e outras perguntas surgem a todo momento e respondê-las não é nem um pouco trivial.

Outro ponto importante é como impedir a propagação dos erros, já que as máquinas do sistema estão interconectadas e, portanto, aptas a receber mensagens de qualquer lugar. Um problema muito comum é uma estação estar com sua tabela de roteamento corrompida e começar a enviar os pacotes para lugares indevidos, o que pode congestionar desnecessariamente certas regiões da rede ou fazer com que pacotes se percam devido à expiração do seu tempo de vida [Tan94]. Uma solução para esse tipo de problema é delegar a certos equipamentos a função de ficar monitorando o funcionamento do sistema periodicamente.

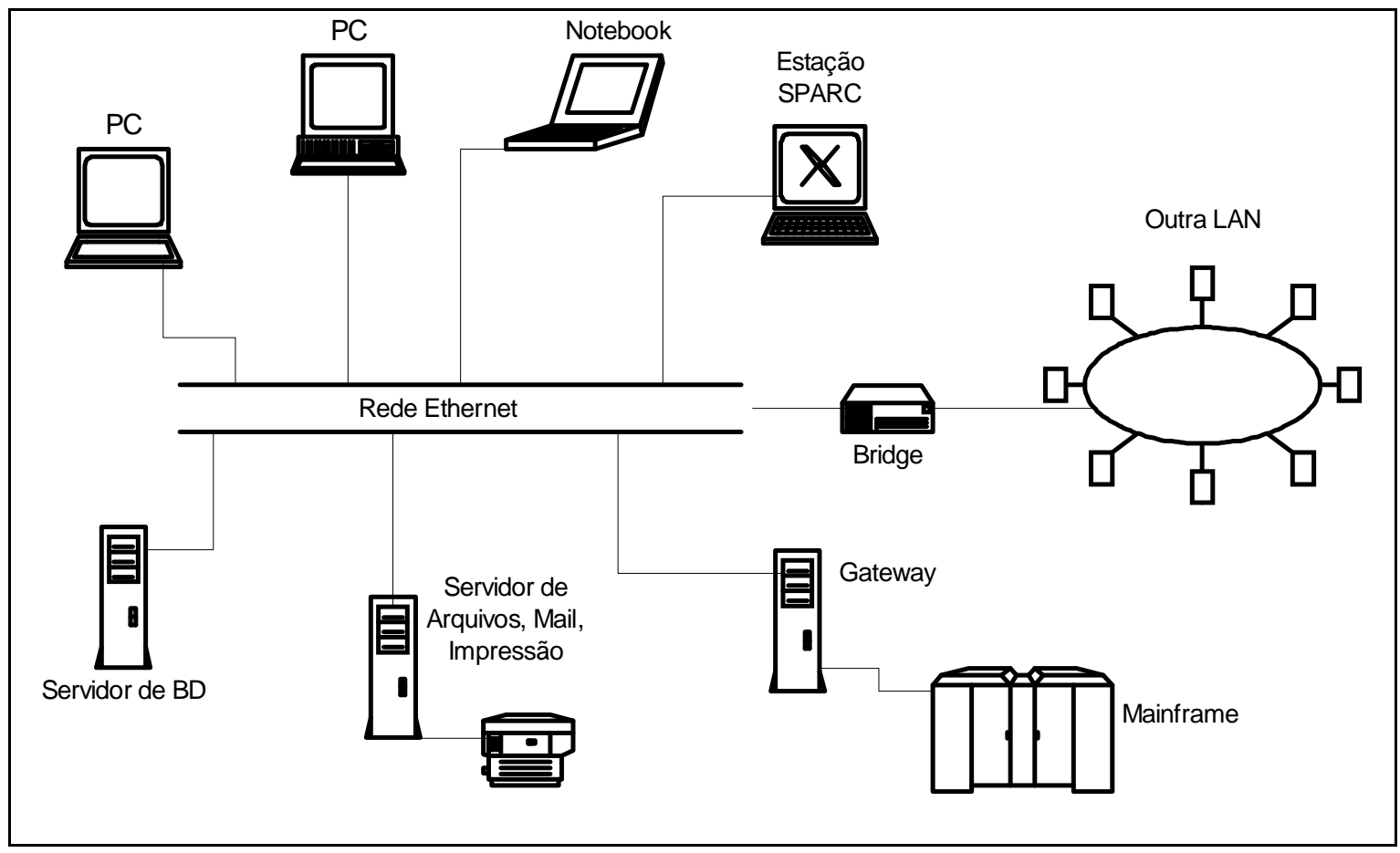

Fig. 2.3 - A diversidade dos componentes de um sistema distribuído 
Evolução do Sistema. Uma das principais vantagens de um sistema distribuído é justamente a sua capacidade de expansão, quase "sem limites" [Ul193], pela simples adição de novas estações de trabalho ou de cabos para integrar novas redes ao mesmo. Contudo, essa evolução tem ser cuidadosamente planejada, para que o sistema não venha simplesmente a "inchar", mas sim que continue a atender a seus usuários de forma satisfatória. Um erro muito comum é simplesmente começar a conectar estações à rede indiscriminadamente, à medida em que elas vão chegando, ou então, seguindo a tendência atual, começar a usar novas aplicações multi-mídia, que sobrecarregam a rede com seus vídeos, sons e outras coisas mais. Não se está dizendo que o sistema não deva evoluir nem que aplicações novas não sejam bem-vindas (ainda bem que elas estão aí!), mas é preciso fazê-lo com responsabilidade, analisando bem se não é necessário modificar a topologia da rede ou trocá-la por uma outra de capacidade maior.

Segurança. Qualquer informação que se coloque na rede sem estar devidamente criptografada deixa imediatamente de ser um segredo. Em um sistema distribuído, devido à capacidade de processamento embutida em cada estação, não é muito difícil para usuários maliciosos criarem seus próprios programas para bisbilhotar o trabalho alheio, fazer-se passar por outrem, ter acesso a arquivos indevidamente e assim por diante. Assim, segurança é um problema sério e tem que ser atacado desde cedo, pois o poder e autonomia colocados na mão de cada usuário do sistema distribuído é bem maior que nos sistemas centralizados. Esta, talvez, seja a "falha" mais freqüentemente apontada por aqueles que ainda resistem aos processos de downsizing atualmente em curso.

Falhas Parciais. Em um sistema distribuído, espera-se que, no caso de falha de um de seus componentes, esta seja isolada e não venha a afetar o funcionamento do sistema como um todo [Mul89]. Para atender este tipo de exigência, é preciso introduzir algoritmos de recuperação nos softwares e planejar com cuidado a redundância de dados e servidores, atentando-se sempre para a possibilidade de surgirem inconsistências.

Como foi visto, os elementos complicadores do projeto, implementação e gerenciamento de sistemas distribuídos são vários e abrangem diversas áreas, algumas ainda não totalmente exploradas. A lista acima, com certeza, poderia ser expandida.

\subsection{O Modelo Clente-Servidor}

\subsection{Conceltos}

Atualmente, o modelo sobre o qual se baseia a maior parte dos sistemas distribuídos é o paradigma Cliente-Servidor. Basicamente, este especifica que existem um conjunto de processos servidores, os quais gerenciam o acesso a um determinado tipo de 
recurso e uma série de processos clientes, os quais necessitam do acesso aos recursos compartilhados para realizar suas tarefas, fazendo, portanto, solicitações aos servidores. Dessa maneira, todo e qualquer recurso existente no sistema distribuído (software, hardware e dados) está sob a guarda de um processo servidor, o qual é o responsável por administrar o acesso concorrente dos diversos clientes ao mesmo.

A fim de firmar bem o conceito de cliente e servidor, considere-se o que diz Ullman [Ul193]: um cliente pode ser qualquer computador ou estação de trabalho conectado ao sistema através da rede, que o usuário utiliza para ter acesso aos recursos disponíveis. Um servidor é uma máquina que provê aos clientes recursos como discos de grande capacidade, bancos de dados, conexões com outras redes, serviços de impressão etc. Os servidores podem ser computadores de grande porte, minicomputadores, estações de trabalho poderosas ou dispositivos de rede.

O modelo cliente-servidor é responsável por muito da flexibilidade e melhor desempenho dos sistemas distribuídos quando comparados aos sistemas centralizados, já que os servidores podem ser espalhados pela rede a fim de ficarem mais próximos dos clientes que os utilizam e é possível dividir a tarefa de gerenciamento entre várias máquinas. Um ponto interessante a esclarecer é que normalmente haverá mais de um servidor para cada tipo de recurso, justamente a fim de atingir as vantagens que se acabou de mencionar, sendo importante diferenciar entre os serviços que o sistema provê aos seus clientes e os servidores que os suportam: o serviço é sempre único; os servidores podem ser vários, inclusive atuando de forma cooperativa [Cou94]. Outro aspecto é que um determinado processo pode ser servidor de outro, mas cliente de um terceiro, o que torna o sistema como um todo bem flexível.

\subsubsection{Vantagens e Desvantagens}

Neste tópico, são destacados alguns dos benefícios e dificuldades encontrados na implantação e gerenciamento de sistemas cliente-servidor. Alguma parte do que será tratado aqui já foi visto nas seções 2.2 e 2.4 com um outro enfoque.

O modelo cliente-servidor permite que diversas máquinas, grandes e pequenas, sejam interligadas. Assim, em um sistema construído segundo uma filosofia desse tipo, não há somente uma máquina (geralmente) da qual dependa o funcionamento de todo o sistema, o que aumenta sua confiabilidade. A capacidade de processamento agregada dessas máquinas é incalculável e os usuários possuem poder de processamento local, graças às estações de trabalho. Os sistemas cliente-servidor também obedecem à filosofia de sistemas abertos, o que significa dizer que não há um único fornecedor, mas vários, aumentando a competitividade e baixando os custos [U1193]. Estes sistemas também 
podem crescer gradativamente, pela adição de uma ou outra estação de trabalho ou periférico, conforme a necessidade. Finalmente, não há um único ambiente de trabalho e aplicativos aos quais todos os usuários tenham que se submeter. Pelo contrário, devido ao poder de processamento de cada estação individualmente, cada usuário pode trabalhar com os aplicativos e ambientes com os quais se sentir mais confortável e que melhor satisfaçam às suas necessidades.

Mas, apesar de todos esses pontos positivos, também há dificuldades: há muito mais com que se preocupar, ou seja, muito mais coisas podem dar errado, devido à diversidade dos equipamentos e à área de abrangência do sistema. Assim, quando ocorre algum problema, é sempre mais difícil isolá-lo e descobrir o culpado e, para solucioná-lo, não é possível simplesmente contactar "aquele" fornecedor que tem resposta para tudo. Nessa nova realidade, o administrador do sistema vai ser, muitas vezes, o responsável por preencher as lacunas deixadas pelos fornecedores. As ferramentas de suporte ao gerenciamento do sistema também não são tão variadas e completas como as existentes para o caso dos sistemas centralizados, embora tenha se evoluído nos últimos anos. A forma de se desenvolver softwares para sistemas cliente-servidor é diferente da programação tradicional e, portanto, é considerável o gasto que se terá com o treinamento da equipe de analistas e programadores.

\subsubsection{Comunicoçào}

Os componentes de um sistema distribuído encontram-se lógica e fisicamente separados e, portanto, para que desempenhem suas tarefas, é necessário que haja uma troca de informações entre eles. No caso particular do modelo cliente-servidor (Fig. 2.4), a comunicação objetiva principalmente a realização de serviços e, basicamente, consiste na transmissão de uma requisição de um processo cliente para um processo servidor, recepção da mensagem e execução da solicitação pelo servidor, e envio de uma resposta ao cliente. O desempenho de um sistema distribuído depende, e muito, da eficiência da comunicação entre suas partes e esta não provém apenas da rede, mas também de quão cuidadosamente o subsistema de comunicação é projetado, a nível de software.

A seguir, são examinadas duas abordagens geralmente utilizadas para a comunicação [Kor93].

\section{Messoge Possing}

Esta é a forma mais simples de todas e faz uso de primitivas básicas de programação do tipo Send e Receive [Tan85]. Acontece entre um par de processos e envolve a transmissão de uma seqüência de valores (uma mensagem) de um processo 
emissor para um receptor através de um meio físico (a rede) e a conseqüente aceitação dessa mensagem pelo processo receptor.

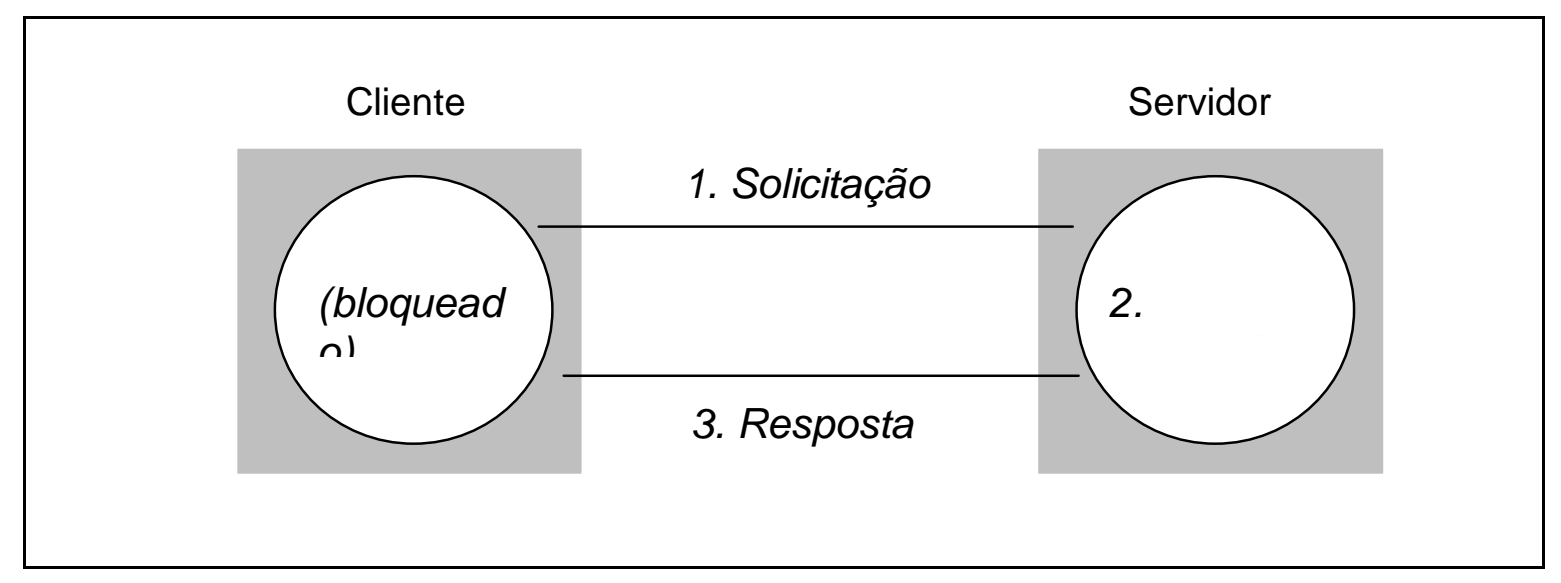

Fig. 2.4 - A Comunicação no Modelo Cliente-Servidor

As primitivas de comunicação podem ser síncronas (bloqueantes) ou assíncronas (não bloqueantes). No caso das primitivas Assíncronas, tão logo o Send seja emitido e a mensagem colocada em uma fila para transmissão, o controle retorna ao programa, não havendo necessidade de aguardar até que a mensagem seja efetivamente enviada. No caso do Receive assíncrono, o programa informa sua intenção de receber uma mensagem e aloca um buffer para a recepção. Quando esta chegar, o programa sofre uma interrupção ou, então, periodicamente faz uma pesquisa (polling) para verificar se a mensagem já chegou. Na abordagem Síncrona, um Send não retornará controle ao programa emissor até que a mensagem tenha sido efetivamente despachada e, se o Send for do tipo confiável, o programa deverá até mesmo aguardar pelo acknowledgement de recepção da mensagem. Um Receive bloqueante paralisa a execução do programa até a chegada de uma mensagem. As primitivas síncronas facilitam a programação, porém implicam em perda de desempenho, já que os programas que as utilizam não podem operar em paralelo com a transmissão e recepção de mensagens.

\section{Remote Procedre Colls (RPCs)}

As chamadas remotas a procedimentos representam o próximo nível de complexidade em relação ao message passing e sua idéia básica é fazer com que a comunicação entre processos em máquinas diferentes seja o mais semelhante possível a uma chamada convencional de procedimentos, conceito que é amplamente dominado pelos programadores em geral. 
O mecanismo de RPCs, por sua simplicidade e por esconder dos programadores os difíceis detalhes de comunicação, tornou-se virtualmente o padrão para a transmissão de mensagens e implementação de aplicações no modelo cliente-servidor e nos sistemas distribuídos de um modo geral. Este, por sinal, é o assunto deste trabalho e será novamente abordado no Capítulo 3.

\subsection{Concluscio}

Neste Capítulo, apresentou-se um panorama geral da área de Sistemas Distribuídos, introduzindo-se alguns conceitos e características dos mesmos. Foram vistas também quais as principais formas de organização arquitetural existentes e quais os desafios que a distribuição de hardware e software impõe ao administrador do sistema. Finalmente, foi abordado o modelo cliente-servidor, solução que tem sido amplamente adotada nas implementações dos sistemas distribuídos atuais, considerando-se suas vantagens, desvantagens e os mecanismos de comunicação utilizados. 


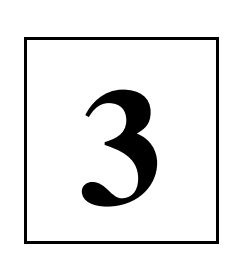

\section{Remote Procedure Calls}

Neste capítulo, iremos abordar aspectos subjacentes ao mecanismo de RPCs, tais como: seu funcionamento, peculiaridades, passagem de parâmetros, binding, tratamento de erros, interconexões assíncronas, geração de código, dentre outros.

\subsection{Introduçāo}

Como já foi visto, no paradigma cliente-servidor, os usuários interagem com aplicações que podem ser clientes de outros serviços disponíveis no sistema. Cada serviço provê uma série de operações que podem ser invocadas pelos clientes. A comunicação entre clientes e servidores se dá através de um mecanismo do tipo send/receive (request/reply).

Os clientes, então, obtêm serviços enviando uma mensagem a um determinado servidor, o qual executa a solicitação e envia uma mensagem de resposta ao cliente, comunicando o resultado da mesma e, eventualmente, mais alguns parâmetros. O cliente, normalmente, fica bloqueado enquanto seu pedido está sendo executado, dando prosseguimento às suas tarefas quando chega a mensagem de resposta.

Todo este processo de enviar mensagens, bloquear-se, aguardar pela conclusão do serviço, etc., é um pouco complicado e exige um certo grau de conhecimento do programador, além de não ser transparente, pois é preciso se preocupar com protocolos utilizados, acknowledgements, sockets e outras coisas mais, não sendo isto nem um pouco trivial para a maioria das pessoas. O mecanismo de Remote Procedure Calls (RPC), 
portanto, vem justamente introduzir uma abstração maior nesse cenário, permitindo que os clientes solicitem tarefas aos servidores simplesmente fazendo chamadas remotas a procedimentos, de uma maneira semelhante à que é utilizada em linguagens de alto nível convencionais.

Dessa forma, um serviço disponível através da rede apresenta-se a seus clientes como um módulo que possui uma interface bem definida de acesso a suas operações, interface esta constituída pelos procedimentos [Cou94]. Isto não só dá uma maior uniformidade de acesso às suas funções, escondendo detalhes de implementação das mesmas, mas também aumenta a segurança do sistema e, evidentemente, sua transparência.

\subsection{Aspectos de uma RPC}

Um dos objetivos de um sistema de RPC é fazer com que as chamadas remotas a procedimentos sejam, pelo menos do ponto de vista do programador, o mais semelhantes possível às chamadas a procedimentos convencionais. Isto, entretanto, não se mostra uma tarefa fácil, pois o ambiente em que é feita a chamada é diferente daquele em que a mesma é executada, o que provoca diversas consequiências interessantes, algumas das quais serão analisadas ao longo deste capítulo.

A primeira e talvez mais peculiar delas é que não é possível fazer, pelo menos da maneira usual, uma chamada a um procedimento passando parâmetros por referência ou com ponteiros, da mesma forma que não faz sentido utilizar variáveis globais. Isto é óbvio, pois, devido à separação entre os ambientes de invocação do procedimento e de execução do mesmo, o único tipo possível de comunicação de parâmetros é através de passagem por valor (veja seção 3.4).

Outro aspecto importante de um sistema que suporta RPC é que o mesmo tem que prover uma Linguagem de Definição de Interface (IDL - Interface Definition Language), a qual especifica com detalhes a interface de cada procedimento que os servidores disponibilizam aos seus clientes, fornecendo o nome dos procedimentos, sua lista de parâmetros, seus tipos e informando se estes são de entrada ou saída. Estas informações constituem as chamadas Procedure Signatures e são de vital importância para a geração das stub procedures (que escondem a complexidade da comunicação dos programadores), sendo utilizadas, ainda, para viabilizar um mecanismo de passagem de parâmetros "por referência". 
Existem duas classes de RPC [Cou94]:

- Na primeira classe, o mecanismo de RPC está integrado a uma linguagem de programação. A vantagem disso é que a IDL faz parte das construções da linguagem e aspectos como tratamento de exceções tornam-se mais fáceis. Exemplos são os sistemas Cedar, Argus e Arjuna [Cou94].

- Na outra classe, é utilizada uma linguagem específica para a definição da interface entre clientes e servidores, tendo a vantagem de não ser necessário aprender uma nova linguagem de programação, aproveitando-se o conhecimento previamente adquirido. Na prática, a linguagem utilizada é a $\mathrm{C}$, que se firmou como um padrão de fato para escrever aplicações desse tipo. Exemplos são o SunRPC, no qual se baseia o NFS (Network File System); o Sistema ANSA e o MIG (sistema operacional Mach).

\subsubsection{Procedimentos Stubs}

Os procedimentos stubs são talvez uma das partes mais importantes de um Sistema de RPC. Sua função é isolar o programador dos detalhes referentes à comunicação através da rede.

Eles se fazem necessários porque, no momento em que o programa "centralizado" é dividido, levando-se algumas de suas subrotinas para uma máquina remota, é preciso introduzir algum elemento que vá assumir o lugar dessa subrotina junto ao módulo que a utiliza e vice-versa. Dessa forma, no lado cliente, o procedimento stub "substitui" o procedimento que foi movido para a máquina remota e, no lado servidor, ele toma o lugar do módulo que iniciou a chamada, ambos os stubs, então, contribuindo para que a separação dos componentes da aplicação se dê de forma transparente ao programador. Observe-se que as funções propriamente ditas das subrotinas estão contidas no código desenvolvido pelo programador, que não é alterado. Os stubs apenas cuidam dos detalhes relativos à troca de mensagens.

Outro aspecto importante de um Sistema de RPC é a Biblioteca RPC (também conhecida como RPC Library ou RPC Runtime API), a qual implementa um conjunto de funções que são utilizadas tanto pelo código da aplicação quanto pelos stubs, reduzindo as chamadas que os procedimentos teriam que fazer a um pequeno conjunto de funções definidas na API, o que facilita a programação na rede e reduz a ocorrência de erros [Kor93]. 
Acompanhe a seção 3.3 a seguir para um melhor detalhamento das atribuições dos procedimentos stubs.

\subsection{Operaçáo de Uma RPC}

Como já foi comentado, o mecanismo de RPC tem que ser transparente, isto é, para o programador as chamadas têm que parecer locais. Para tanto, é necessário introduzir alguns elementos que vão esconder as complexidades inerentes ao problema. Nesta seção, são analisados cada um deles à medida em que se estudam as etapas envolvidas em uma chamada remota (Fig. 3.1).

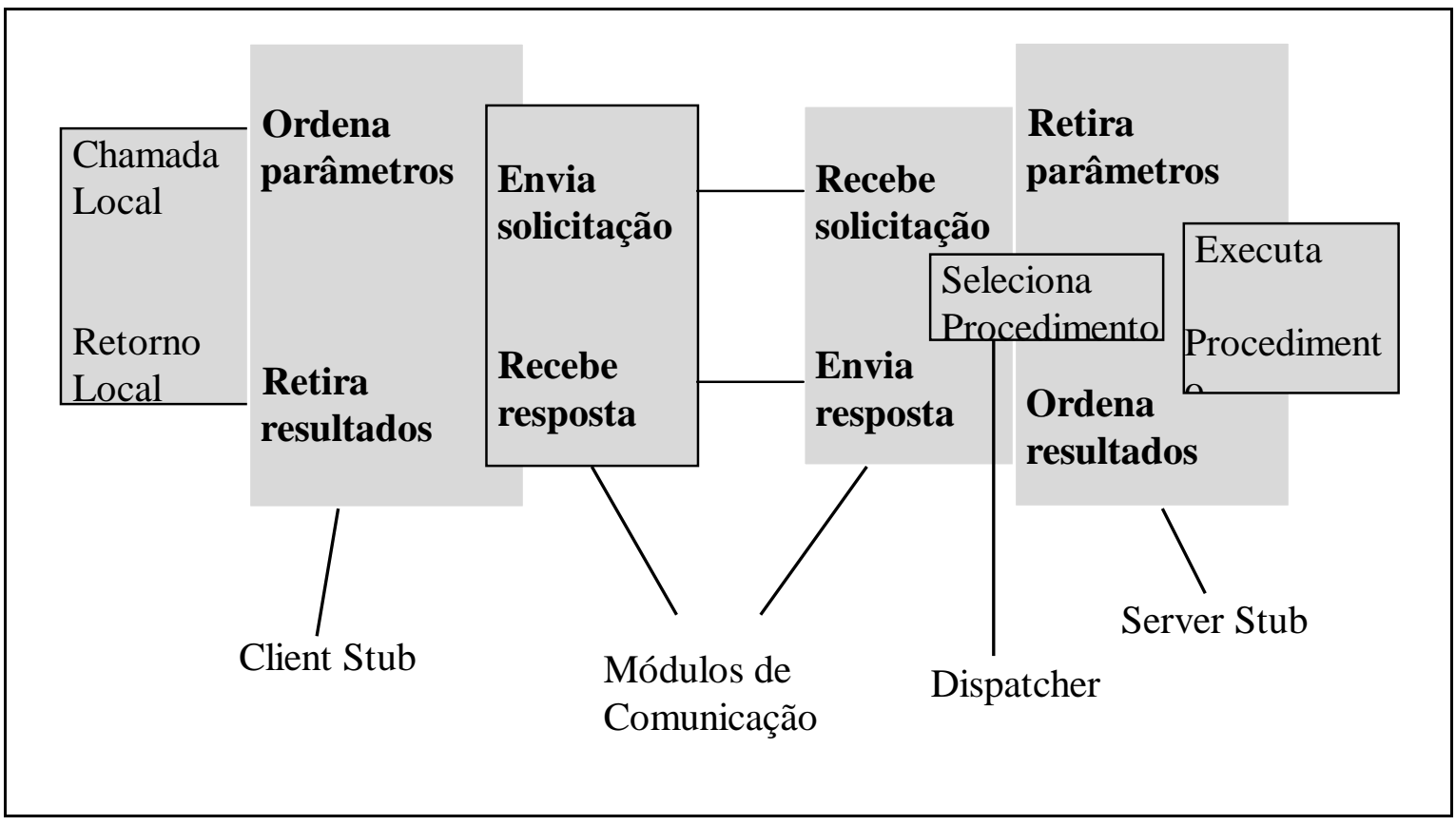

Fig. 3.1 - Operação de uma Remote Procedure Call

Ao ser feita uma chamada a um procedimento remoto, da mesma forma que em uma chamada local, os parâmetros são colocados na pilha, assim como é guardado o endereço de retorno. Entretanto, ao invés de se chamar o procedimento propriamente dito, é invocado um client stub, o qual coloca os parâmetros em uma mensagem (marshalling), juntamente com uma identificação do procedimento chamado e envia a mensagem ao servidor, bloqueando-se, em seguida, até que chegue a resposta. Quando esta chega ao lado servidor, o dispatcher identifica qual o procedimento sendo solicitado e passa a tarefa ao server stub apropriado, o qual retira os parâmetros da mensagem 
(unmarshalling) e chama o procedimento servidor "real" da maneira usual, ou seja, colocando os parâmetros na pilha e passando o controle ao mesmo.

O procedimento servidor, então, executa o trabalho que lhe compete e retorna os resultados ao server stub, o qual compõe uma nova mensagem e a envia de volta ao cliente. O client stub irá recebê-la e fazer um retorno da maneira usual à rotina que invocou a RPC.

Observe-se que, durante todo este processo, o cliente não tem a mínima idéia se o trabalho executado foi local ou remoto, da mesma forma que o servidor não sabe se a solicitação foi feita localmente ou através da rede. Neste "desconhecimento" consiste toda a elegância do mecanismo de RPC, pois todos os detalhes relativos à comunicação ficam a cargo dos stubs.

Os stubs são gerados a partir da linguagem de definição de interface (IDL), a qual especifica em detalhes tudo o que se precisa saber para chamar um procedimento, como já foi visto. No lado cliente, as aplicações são encadeadas não com os procedimentos reais mas sim com os client stubs e, no lado servidor, há um server stub para cada procedimento definido, sendo que cada um deles recebe um número identificador. $\mathrm{O}$ responsável pela geração desses procedimentos "falsos" é o compilador de interface, que o faz a partir da IDL.

Aliás, é justamente nessa área, a geração automática de procedimentos stubs, que está centrado o trabalho proposto nesta dissertação, procurando torná-la o mais transparente possível ao programador, a fim de que este possa desenvolver aplicações distribuídas quase como se estivesse desenvolvendo aplicações centralizadas.

\subsection{Possagem de Parámetros}

Em princípio, a função dos stubs parece simples: receber os parâmetros/resultados, agrupá-los em uma mensagem e enviá-los ao servidor/cliente. Entretanto, existem várias questões que tornam essa tarefa mais difícil do que aparenta [Tan92].

Suponha-se que se tenha uma função int $\operatorname{mul}(x, y)$. Se esta fosse executada como uma RPC (embora isto não faça muito sentido), os parâmetros $x$ e $y$ seriam empacotados em uma mensagem, juntamente com a identificação do procedimento e esta enviada ao servidor para processamento. Mesmo numa simples função desse tipo, em que a passagem dos parâmetros é apenas por valor, já é possível antever algumas complicações. Em primeiro lugar, há o problema de como representar os dados. Os PCs IBM, por 
exemplo, utilizam o código ASCII, enquanto mainframes da própria IBM fazem uso da codificação EBCDIC. Há também o problema da representação de inteiros negativos (complemento de 1 ou 2) e de números de ponto flutuante. Pior ainda, há diferenças na maneira como os bytes são armazenados na memória principal: máquinas Intel numeram os seus bytes da direita para a esquerda, isto é, começando pelo byte de mais baixa ordem. Já chips SPARC o fazem da esquerda para a direita, começando pelo byte de mais alta ordem. Assim, ao transmitir inteiros entre máquinas desse tipo é preciso tomar cuidado para fazer as conversões necessárias ou então se terá valores absurdos.

A solução normalmente adotada para esses casos é utilizar um formato da rede (dito canônico) para a transmissão dos dados, fazendo com que todos aqueles que desejam enviar dados os convertam de seu formato interno para o formato homologado na rede; do outro lado, aqueles que recebem dados deverão saber convertê-los do formato da rede para a representação que usam internamente. Um problema que se nota nesse esquema é que, se duas máquinas do mesmo tipo estão se comunicando (p.ex., SPARC x SPARC), as conversões de e para o formato da rede são desnecessárias, contribuindo para introduzir uma sobrecarga a mais na comunicação, como se já não bastassem as cópias de dados que são feitas durante uma RPC. Uma solução é deixar a conversão a cargo do receptor e não daquele que envia a mensagem, ou seja, ao receber uma mensagem, examina-se um dado byte para saber se o emissor é do mesmo tipo do receptor. Se for, então não é preciso fazer conversões para o formato da máquina local; caso contrário, realizam-se as transformações necessárias.

E quanto à passagem de parâmetros por referência? Neste caso, não faz sentido usar ponteiros, uma vez que o significado dos mesmos restringe-se ao ambiente em que foram criados. A solução utilizada é enviar uma cópia dos parâmetros na mensagem de ida e fazer com que o procedimento receptor atue sobre esta cópia, localmente. Ao término do procedimento, os novos valores são copiados sobre os antigos e os parâmetros enviados na mensagem de volta. Embora não se tenha feito realmente uma chamada por referência, na prática o significado é o mesmo. Este tipo de passagem de parâmetros é utilizado na linguagem ADA e denomina-se copy/restore.

O senão dessa abordagem é que há o overhead de transmitir os parâmetros na mensagem de ida e de volta, o que demanda tempo, considerando-se o trajeto que a mensagem tem que fazer. Uma maneira de otimizar isso é a seguinte: no caso de parâmetros só de entrada (em relação ao servidor), não é necessário copiá-los de volta para o cliente; no caso de parâmetros só de saída, não precisam ser enviados ao servidor. Estas informações quanto a parâmetros de entrada/saída são obtidas a partir da linguagem de definição de interface. 
Finalmente, há o problema de passar ponteiros para estruturas complexas como listas encadeadas, árvores, grafos. Nestes casos, o que se usa são as chamadas referências opacas, ou seja, o servidor devolve ao cliente, ou vice-versa, um valor (que pode ser um ponteiro para a raiz de uma árvore-B, por exemplo) que não faz sentido no ambiente do cliente, mas que este assume como verdadeiro e passa a utilizá-lo em referências futuras à estrutura de dados criada no ambiente servidor. Outra técnica possível é usar algoritmos de representação de estruturas de dados em vetores, mas que, é claro, não pode ser aplicada a todos os casos.

\section{5 "B.Indlng"}

Até o presente momento, ignorou-se o fato de que o cliente, para executar um serviço, precisa saber a localização do servidor, já que a mensagem com o pedido tem que ser endereçada a algum lugar.

Uma solução rudimentar seria colocar o endereço de rede do servidor dentro do próprio programa, porém isto é bastante inflexível, uma vez que, se o servidor for movimentado na rede, é necessário recompilar todos os programas que fazem uso dele.

Outra alternativa é fazer o mapeamento de cada serviço em uma porta específica de um dado servidor, dinamicamente. Este serviço que, dado o nome de um procedimento, fornece um servidor capaz de atendê-lo, é denominado binding e é uma das peças centrais em um sistema de RPC, podendo ser comparado a uma espécie de servidor de nomes para o RPC. Além da vantagem da flexibilidade, ele também permite, dentre outras coisas:

- balancear os clientes entre os servidores;

- que o servidor escolha aqueles clientes que deseja atender, podendo-se usar um mecanismo de prioridades;

- controle de versão de procedimentos.

Uma possível "desvantagem" do binding dinâmico é que os clientes precisam, antes de iniciar uma chamada remota, enviar ao binder uma mensagem para localizar o servidor, o que introduz um certo overhead, podendo o binder vir a se tornar um gargalo do sistema, se ele for o único existente. Uma alternativa é haver múltiplos binders, tendo-se, entretanto, que ter o cuidado de manter a informação contida neles consistente.

A interface do binder pode se apresentar da seguinte forma [Cou94]: 
PROCEDURE Register (Servico:String; Porta:Port; Versao:Int)

Solicita ao binder que registre o nome de um serviço, seu endereço de acesso e número de versão.

PROCEDURE WithDraw (Servico:String; Porta:Port; Versao:Int)

Solicita ao binder que retire um determinado serviço de sua tabela.

PROCEDURE LookUp (Servico:String; Versao:Integer) : Port

O binder procura por um serviço em sua tabela e retorna o endereço

de acesso se o número da versão for compatível.

O procedimento Register() é utilizado por cada servidor assim que este entra em funcionamento, a fim de deixar assinalado no sistema que ele é capaz de executar aquele serviço, com uma certa versão. Se um servidor deixa de oferecer um serviço ou vai fazer uma manutenção no procedimento que o atende, pode utilizar o procedimento Withdraw() para retirá-lo da tabela do binder. Os clientes fazem uso do procedimento $\operatorname{LookUp}($ ) cada vez que desejam iniciar uma RPC a fim de saber para onde enviar a mensagem.

A comunicação com o binder se dá através de RPC, surgindo, então, a pergunta: como localizar o binder? Soluções possíveis são fazer com que o mesmo possua um endereço conhecido por todos; mantê-lo numa variável de ambiente ou então fazer um broadcast ao qual o binder vai responder indicando sua localização.

Como exemplo, em sistemas UNIX não há um serviço de binding, a rigor. O que existe é, em cada servidor, numa porta pré-determinada, o chamado port mapper, cuja função é indicar as portas para acesso a todos os serviços providos por aquele servidor. $\mathrm{O}$ endereço do servidor/serviço no UNIX é dado por: endereço IP + port number $\Rightarrow$ socket.

\subsection{Possivels Falhas durante uma RPC}

Como já foi dito algumas vezes, o mecanismo de RPC tem que ser o mais transparente possível e, ao longo deste capítulo, foram vistos alguns artifícios para se conseguir isso. No entanto, resta ainda o problema do tratamento de erros, pois, dado que cliente e servidor encontram-se em ambientes diferentes, surgem novos tipos de falhas que precisam ser contemplados [Tan92]. 


\subsubsection{Cliente nào consegue localizar o Servidor}

Isto pode acontecer por duas razões: o servidor está fora do ar ou então aquele determinado programa foi compilado com um client stub desatualizado, ou seja, não existe registrado no binder um procedimento com a versão solicitada. O que se pode fazer aqui é, após enviar cada solicitação, disparar um timer; se este expirar, envia-se o pedido novamente até que seja atingido um limite máximo de repetições, quando então ocorre uma exceção, que precisa ser tratada pelo programa cliente. Observe que esta solução só funciona se a operação solicitada for Idempotente (pode ser repetida sem causar dano às informações).

\subsubsection{Perda de Mensagens de Solicitaçào de Serviços}

Uma mensagem pode se perder na rede e então o serviço solicitado deixará de ser executado não por falha do servidor, mas porque este não recebeu o pedido devido. A solução também é usar um timer para controlar o reenvio das mensagens, com o mesmo problema descrito acima.

\subsubsection{Perda de Mensagens de Resposta}

Também se usa um timer para solucionar o problema, mas fica a dúvida sobre o que realmente ocorreu:

- a solicitação se perdeu ?

- a resposta se perdeu ?

- o servidor está sobrecarregado ?

$\mathrm{Na}$ verdade, estas perguntas se aplicam a todos os casos descritos e respondê-las não é fácil. Para evitar o perigo de se executar mais de uma vez operações não idempotentes, pode-se fazer com que cada mensagem RPC contenha um número de sequiência para que o servidor diferencie mensagens novas de antigas, ou então, de forma mais simples, usar um bit indicando se a mensagem é inédita ou uma repetição.

\subsubsection{Crash do Servidor}


Um outro tipo de falha, talvez a mais séria de todas, é o crash do servidor, não sendo possível resolvê-la através de simples números de sequiência. A figura 3.2 mostra as diferentes situações encontradas.

O caso (a) é aquele em que tudo dá certo e não há com que se preocupar. No caso (b), a solicitação foi executada e, portanto, não sendo a operação idempotente, não é possível executá-la de novo. Na situação (c), por sorte nada foi feito antes que o servidor quebrasse. O enigma aqui é descobrir o que aconteceu, o que é difícil, já que, com o servidor quebrado, não é póssível obter nenhuma informação sobre o resultado da RPC.

O que é preciso, então, é definir que tipo de semântica se espera da chamada RPC, que são os seguintes:

- Semântica Maybe $\rightarrow$ Não é assegurada a tolerância a falhas. Em geral, os clientes não são capazes de determinar se a chamada foi efetivamente executada. Fácil de implementar, porém não é uma solução aceitável para a maioria dos casos.

- Semântica At-least-once $\rightarrow$ Garante que a solicitação foi executada uma ou mais vezes. Se as operações do servidor são todas idempotentes, então não há problemas.

- Semântica At-most-once $\rightarrow$ Garante que a solicitação foi executada no máximo uma vez, mas pode também não ter sido executada. É a semântica mais utilizada nas implementações de RPCs [Cou94].

- Semântica Exactly-once $\rightarrow$ A chamada é executada uma única vez. Seria o tipo ideal de semântica, mas é difícil consegui-lo.

\subsubsection{Crash do Cliente}

Quando um cliente pára de operar, as solicitações dele que estavam sendo processadas perdem o sentido, pois não há ninguém aguardando o resultado de seu trabalho. Estas solicitações são chamadas de órfãs e precisam ser tratadas com cuidado, uma vez que desperdiçam tempo de processador e podem estar executando bloqueios em alguns recursos valiosos do sistema.

Uma solução seria escrever um log de cada chamada RPC, a fim de ser possível desfazê-la, se necessário; na prática, isto leva à perda de desempenho e poderia requerer um espaço considerável no disco, já que o número de RPCs em andamento em um sistema é grande.

Outro esquema é usar a chamada reencarnação: o tempo é dividido em intervalos numerados seqüencialmente denominados épocas; quando um cliente é reiniciado, este declara o nascimento de uma nova época enviando um broadcast pela rede. Os 
servidores, ao receberem a mensagem, verificam se possuem algum procedimento em execução de uma época anterior; se o encontram, então este é "abortado". Se for usada a reencarnação "gentill", então os servidores tentam localizar o proprietário de cada operação órfã a fim de aproveitar o serviço que já foi realizado.

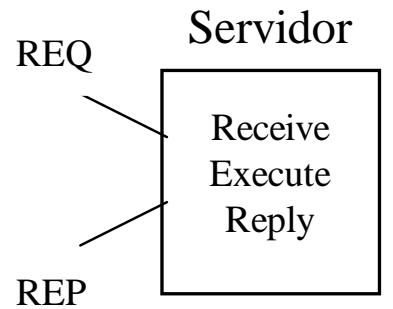

(a)

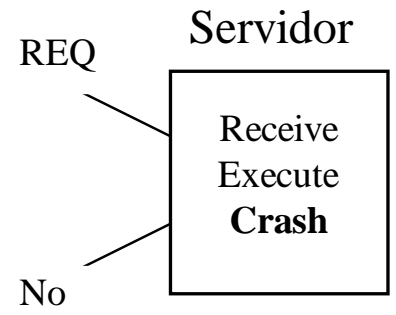

(b)

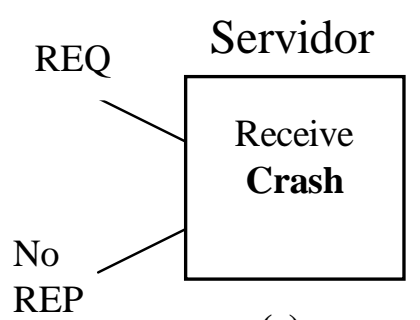

(c)

Fig. 3.2 - (a) Situação normal, (b) Crash depois de executar, (c) Crash antes de executar

Finalmente, pode-se usar o mecanismo de expiração. Neste caso, cada RPC recebe um tempo máximo em que pode ficar executando, ao final do qual ela é destruída. A dificuldade é que, dada a diversidade de tipos de chamadas possíveis, fica complicado estabelecer um intervalo médio de tempo que se aplique a todos os casos.

\subsection{RPC Assíncrono}

Uma variação em torno do tema RPC são as interconexões assíncronas ou RPC assíncrono, que são um tipo de RPC que não exige que o cliente se bloqueie aguardando a resposta do servidor e, às vezes, não requer nem mesmo que uma resposta seja enviada.

A rigor, não se poderia chamar uma interação cliente/servidor deste tipo de RPC, uma vez que o bloqueio do módulo que chamou a rotina (pré-requisito básico de uma 
chamada a procedimentos) não ocorre, porém este termo já se firmou na literatura sobre o assunto.

O benefício do RPC assíncrono é que ele vem justamente eliminar algumas "desvantagens" do RPC convencional, como, por exemplo, a necessidade do cliente bloquear-se esperando pela resposta do servidor, ao invés de ficar executando outras operações em paralelo, o que melhoraria a resposta do sistema. Por outro lado, a programação utilizando primitivas asssíncronas é mais complexa e, no caso de requisições que não pedem uma resposta, fica difícil saber se estas foram executadas no servidor.

De qualquer forma, há casos em que é vantajoso utilizar o RPC assíncrono. Por exemplo [Cou94]: sistemas de janelas geralmente usam alguma forma de comunicação assíncrona. O sistema, nesse caso, é programado como um servidor e os programas que quiserem mostrar textos ou gráficos em uma janela devem enviar solicitações a ele. Aqui, fica clara a melhoria de desempenho proporcionada pelo RPC assíncrono, uma vez que a mensagem do cliente, muitas vezes, é um caracter ou um movimento do apontador do mouse e a resposta vem a ser a própria alteração na tela, não sendo necessário e até indesejável o bloqueio do cliente a cada tecla pressionada. Uma melhoria, inclusive, seria armazenar diversas solicitações do cliente e enviá-las ao servidor em intervalos de tempo pré-determinados (de milissegundos), de modo a fazer melhor uso capacidade da rede, uma vez que uma RPC já possui um overhead inevitável. O RPC assíncrono também possibilita que um cliente envie requisições em paralelo a diversos servidores.

\subsection{Geraçáo de Códlgo}

O mecanismo de RPC tem que ser transparente ao programador, isto é, este deve se concentrar na aplicação que está desenvolvendo e não nos detalhes de como vai ser feita a comunicação entre cliente e servidor (na verdade, se o programador não tiver consciência da existência de um servidor nem da rede, melhor ainda).

A Geração de Código aqui referida engloba a geração dos procedimentos stubs, tanto do lado cliente quanto servidor, podendo ser feita manualmente ou de modo automático.

A geração manual é extremamente tediosa e bastante suscetível a erros, pois o programador vai ter que se preocupar com aspectos como onde encontrar o servidor que oferece um serviço em particular, qual protocolo de comunicação utilizar, tratamento de mensagens perdidas, acknowledgements, possivelmente criptografia e assim por diante. Estas tarefas não são nem um pouco fáceis e exigem um certo grau de conhecimento 
técnico do programador, além de ficar claro que, se ele tiver que tomar conta de tudo isso, a maior parte do tempo consumido no projeto será justamente com esses detallhes, tempo que poderia ser melhor utilizado na depuração do sistema sendo desenvolvido.

Por estas razões, opta-se sempre por uma geração automática de código (stubs), pois, assim, os detalhes da comunicação ficam escondidos dos programadores, podendo estes concentrar-se na sua real tarefa, que é desenvolver sistemas, o que implica em um aumento de produtividade. Outra vantagem é que, como as funções realizadas pelos stubs são bastante repetitivas (receber a chamada, empacotar os parâmetros em uma mensagem, enviá-la etc.), a geração destes, automaticamente, por um sistema já bem depurado, permite que seu código seja otimizado ao máximo e detalhes como protocolo utilizado, modo de operação síncrono ou assíncrono e outros, podem ser modificados sem alterações na forma de utilização do sistema. Se os stubs forem escritos segundo uma filosofia orientada a objetos, o grau de independência e facilidade de manutenção torna-se ainda maior.

No próximo capítulo, é abordada a forma como são utilizadas as chamadas remotas a procedimentos em diferentes sistemas, podendo-se ter, então, uma idéia melhor do processo de construção das aplicações distribuídas.

\subsection{Concluscio}

No presente Capítulo, foi discutido o mecanismo de RPCs, o qual se constitui na base para a comunicação entre os componentes da maioria dos sistemas cliente-servidor. Foram abordados seus aspectos principais, as diferenças em relação às chamadas a procedimentos convencionais, a problemática do gerenciamento de falhas, da localização do servidor pelo cliente (binding), dentre outros. Finalmente, comentou-se sobre as interconexões assíncronas e sua aplicabilidade e também sobre o ganho de produtividade que a geração automática dos procedimentos stubs proporciona se comparada com a geração manual. 


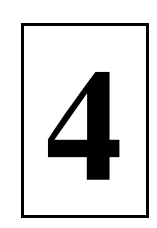

\section{Aplicações Distribuídas Baseadas em RPC}

Neste capítulo, serão vistos quais os desafios que esperam por aqueles que se aventuram a escrever aplicações distribuídas, sendo fornecidas algumas orientações acerca de como proceder para ser bem-sucedido nessa árdua tarefa. Particularmente, destaca-se a importância da tecnologia de RPCs no sentido de isolar os programadores das complexidades do sistema distribuído. São abordados, também, os mecanismos de RPC utilizados nos ambientes Sun, MS-DOS e Windows, analisando-se as peculiaridades de cada um.

\subsection{Introduçōo}

Atualmente, com a procura cada vez mais intensa por poder de processamento, face às demandas que os novos tipos de aplicações impõem, tornou-se necessário encontrar soluções para fornecer mais poder computacional a um custo menor. Os sistemas baseados em um único processador, como é sabido, possuem um limite até mesmo físico para a resposta que podem dar a uma aplicação.

Assim, uma das soluções que se vem adotando, já há algum tempo, são máquinas com múltiplos processadores. Contudo, neste caso, há o problema do custo alto e da própria manutenção destas máquinas e da construção de algoritmos paralelos.

Sendo assim, a solução "vencedora" até agora tem sido justamente a utilização dos sistemas distribuídos, que permitem que, através de uma rede, se integrem 
múltiplos processadores, fracamente acoplados, de modo a formar um ambiente de computação único, visto como um todo por seus usuários e aplicações.

Para que este todo funcione, é preciso que seus componentes troquem informações, cooperando entre si. A rede fornece o suporte físico para isso e, a nível de software, o middleware [Kor93] provê a base para a movimentação de dados entre os componentes, através de uma API (Application Programming Interface) padrão que reduz o tempo necessário para o desenvolvimento de aplicações distribuídas, já que os programadores são "presenteados" com uma interface limpa que lhes esconde as complexidades da rede. Como exemplos de middleware (seção 2.5), tem-se os sistemas de passagem de mensagens e os mecanismos de RPC (Capítulo 3).

As chamadas remotas a procedimentos, assunto deste trabalho, permitem que se execute um procedimento em uma máquina remota, diferente daquela em que a chamada se originou. As RPCs constituem a base para o paradigma cliente-servidor e permitem que a carga de trabalho seja distribuída através das máquinas conectadas pela rede, que passam a ser utilizadas como um único processador virtual.

\section{Construçāo de Aplicaçōes Distribuidas}

\subsubsection{Consideraçós riclas}

A computação distribuída implica em pelo menos dois computadores conectados por uma rede, trabalhando cooperativamente e compartilhando recursos lógicos (arquivos, programas) ou físicos (impressoras, discos) [Blo95]. Não se discute mais que muitas vantagens advêm do uso de sistemas distribuídos, como, por exemplo: maior disponibilidade do sistema, melhores interfaces com o usuário, melhor tempo de resposta, maior flexibilidade e assim por diante.

Entretanto, tudo isso não vem de graça. Se há uma dificuldade que surgiu junto com os sistemas distribuídos, esta foi justamente o problema da construção das aplicações distribuídas. Em linhas gerais, os novos desafios que os projetistas e programadores têm que enfrentar são os seguintes [Blo95]:

- Localização dos Recursos. Estes não se encontram mais na máquina local e, portanto, as aplicações devem conter mecanismos para sua localização e uso eficiente.

- Consistência dos Dados. Em um sistema distribuído, geralmente existem múltiplas cópias dos dados espalhadas pela rede, por razões de confiabilidade e melhoria no desempenho (nos acessos aos dados). Assim, mecanismos de compartilhamento e bloqueio devem também estar presentes nas aplicações. 
- Sincronização e Temporização. Os diversos relógios utilizados no sistema têm que ser mantidos em sincronia e as aplicações têm que estar cientes dos problemas de temporização, devido a atrasos ocasionados por congestionamento na rede ou falha de um servidor.

- Fragmentação da Informação. A aplicação cliente não é possuidora de toda a informação disponível acerca de uma conexão com um servidor, nem tampouco existe um espaço de memória compartilhado entre ambos. Portanto, é preciso estabelecer políticas e prover mecanismos de recuperação de contexto no caso de falha de quaisquer dos participantes.

\subsubsection{Desemvolvimento das Aplcoçðos}

No desenvolvimento de aplicações distribuídas, existem dois paradigmas que se pode adotar [Com93]: o projeto orientado à comunicação e o projeto orientado à aplicação.

No Projeto Orientado à Comunicação, o programador inicia seu trabalho pelo protocolo utilizado, definindo um formato para as mensagens e como os componentes cliente e servidor reagirão à chegada das mesmas e também quais mensagens serão enviadas, face às diferentes situações que podem vir a ocorrer durante o funcionamento da aplicação. O problema dessa abordagem é que poucos programadores e projetistas são capazes de compreender ou conceber uma aplicação sob o ponto de vista de troca de mensagens, pela falta de experiência com o projeto de protocolos. Além disso, a comunicação passa a ser o centro das atenções, ao invés da aplicação em si, o que desvia a atenção do problema que se quer resolver, dificultando, ainda, futuras manutenções do sistema.

O Projeto Orientado à Aplicação, por outro lado, utiliza técnicas e abordagens já conhecidas da construção de aplicações centralizadas, fazendo com que os profissionais se concentrem na aplicação a ser desenvolvida e não em detalhes "menores" e repetitivos relacionados com a comunicação e distribuição dos recursos pela rede. Nessa abordagem, é quase que universalmente adotado o Modelo ClienteServidor para a construção das aplicações distribuídas, já discutido anteriormente (seção 2.5). Neste, o padrão para a troca de mensagens são as RPCs (Capítulo 3), as quais separam a solução do problema da tarefa de fazer a solução funcionar em um ambiente distribuído [Com93].

De posse de um mecanismo de RPCs, o programador pode se preocupar com os detalhes da aplicação que tem que ser desenvolvida, resolvendo o problema da maneira convencional, para só então se preocupar em dividir a aplicação em partes que serão executadas em diferentes computadores. 
Para permitir essa independência, o sistema de RPCs provê ferramentas para a geração automática de código e também funções pré-definidas em uma biblioteca, as quais são utilizadas pelas aplicações e pelos stubs para o acesso à rede. A figura 4.1 mostra onde reside o mecanismo de RPC em um ambiente que dá suporte a aplicações distribuídas.

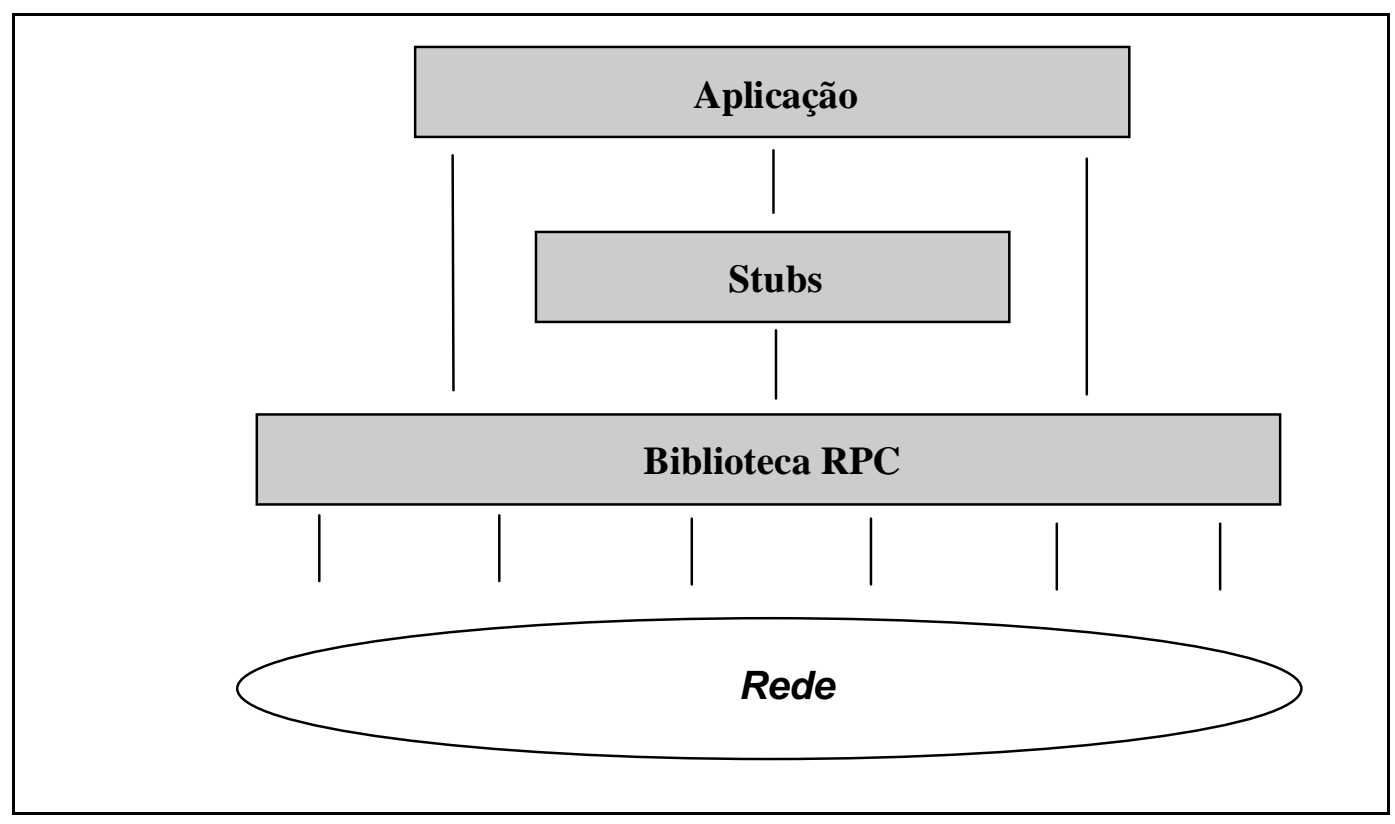

Fig. 4.1 - O Relacionamento entre as aplicações, os stubs e a Biblioteca RPC

Como se pode ver, os stubs e a Biblioteca RPC isolam os programadores das particularidades da troca de mensagens pela rede e, na maioria das vezes, estes só têm que se preocupar com algumas poucas funções necessárias para realizar o binding do cliente e do servidor e o registro dos serviços junto ao port mapper (seção 3.5).

Dessa forma, o conceito de chamadas a procedimentos remotos permite que os programadores trabalhem em um ambiente familiar, a que estão acostumados [Com93]. Do mesmo modo que em uma chamada a procedimentos convencional, uma RPC transfere o controle para o procedimento chamado, suspendendo a execução do módulo que iniciou a chamada. O conceito de chamadas aninhadas também está presente: uma RPC pode chamar uma outra RPC e, neste caso, o procedimento servidor torna-se cliente de um outro serviço.

Por mais que haja semelhanças, no entanto, há diferenças importantes a considerar, como passagem de parâmetros, a sobrecarga considerável imposta por uma RPC, os ambientes de execução diferentes e outras. Nesse contexto, um sistema será tanto mais evoluído quanto maior for o grau de isolamento, que proporciona aos programadores, em relação aos detalhes acima. 


\subsubsection{Subdviscio dos Apllcoçdes}

Outra questão que surge no desenvolvimento de aplicações distribuídas é como subdividir a aplicação, ou seja, quais partes deverão ser executadas localmente e quais deverão ser transportadas para os servidores. Bloomer [Blo95] enumera alguns questionamentos que o projetista deve fazer:

- Há uma separação funcional entre cliente e servidor ? Claro que a solução nem sempre vai ser colocar o programa principal no cliente e todos os procedimentos no servidor. Quanto mais modular for o programa, mais fácil será a separação de seus componentes.

- Foi considerado o trânsito dos dados pela rede quando da subdivisão da aplicação? Mesmo que a aplicação esteja bem estruturada, isso não significa que este seja o melhor meio de dividi-la. É preciso considerar a quantidade de dados que será enviada pela rede, a fim de minimizar a carga na mesma.

- É grande o número de variáveis globais ? Se isso for verdade, pode ser preciso repensar a aplicação desenvolvida ou então desenvolver funções específicas para a troca de parâmetros globais entre cliente e servidor ou, ainda, incluir as variáveis globais em cada chamada a procedimento. Raciocínio semelhante vale para o uso intenso de estruturas ligadas por ponteiros.

- A aplicação utiliza mecanismos como semáforos, memória compartilhada ou sinais ? Se utilizar, é preciso encontrar maneiras de isolá-los no ambiente cliente ou servidor ou, então, prover formas de emulação dos mesmos através das RPCs.

Pelo que foi exposto, é possível observar que a tão desejada transparência do sistema distribuído, provida em parte pelas RPCs, nem sempre é total e, portanto, o programador "distribuído" precisa ter bem mais conhecimento e habilidade que seus colegas "centralizados".

Nas seções seguintes, serão analisadas particularidades da construção de aplicações distribuídas, baseadas em RPC, nos ambientes Sun, MS-DOS e Windows.

\subsection{OAmbiente Sun}

Embora não tenha sido a primeira implementação de um Sistema de RPC, a qual se deve ao pacote Courier, da Xerox, o Sun RPC é, seguramente, a mais bemsucedida das implementações de chamadas remotas a procedimentos, tendo, inclusive, contribuído para disseminar o uso de RPCs no meio acadêmico e fora dele, dada a sua popularidade. 
O Sun RPC compõe-se das seguintes partes [Ste90]:

- Um Compilador de Interface, o rpcgen, que recebe a definição de uma ou mais interfaces de procedimentos remotos e, a partir dela, gera os procedimentos stubs do lado cliente e servidor;

- Uma Biblioteca RPC (RPC Library) que se encarrega de tratar dos detalhes relativos às RPCs e à comunicação através da rede;

- Uma representação de dados padrão (XDR - eXternal Data Representation) para facilitar a troca de dados entre sistemas diferentes, a qual se constitui no formato canônico (seção 3.4) adotado para envio de pacotes pela rede.

Para gerar uma aplicação utilizando-se o sistema de RPC da Sun, deve-se seguir os seguintes passos [Com93], os quais não mudam muito em relação a outros sistemas que dão suporte a RPCs:

a. Construir e testar uma aplicação "centralizada" convencional para resolver o problema;

b. Dividir o programa em partes cliente e servidor, isto é, determinar quais os procedimentos que serão executados remotamente e quais deverão permanecer locais. Estes dois passos iniciais contituem mais uma abordagem aconselhável para a programação de aplicações distribuídas do que exigências do Sun RPC e não necessariamente têm que ser seguidos à risca. Contudo, é extremamente produtivo fazer a ligação dos procedimentos servidores inicialmente com o lado cliente da aplicação, a fim de depurá-la localmente, antes de se efetuar sua distribuição pela rede [Blo95];

c. Construir a especificação da interface dos procedimentos remotos, que será submetida ao rpcgen, a qual define quais são os procedimentos, os tipos de seus parâmetros, valores de retorno e também quaisquer constantes usadas pelo cliente ou servidor e tipos de dados (structs);

d. Submeter a especificação ao rpcgen, a fim de que ele gere os procedimentos stubs e outros arquivos que serão ligados com as aplicações cliente e servidora. Mais detalhes sobre cada tipo de arquivo na seção 4.3.1.

e. Compilar e ligar o programa cliente com os seguintes arquivos: a aplicação originalmente escrita pelo programador (sem os procedimentos remotos), o stub cliente e os procedimentos XDR (para conversão dos dados, também gerados pelo rpcgen); 
f. Compilar e ligar o programa servidor com os seguintes arquivos: os procedimentos remotos retirados da aplicação original, o stub servidor e os procedimentos XDR;

g. Iniciar a execução do servidor na máquina remota e executar o cliente localmente.

\subsubsection{Uma Aplloç̧äo Exomplo}

A seguir, será analisado um exemplo de geração de uma aplicação clienteservidor simples usando o Sun RPC.

O objetivo da aplicação é fornecer facilidades para o gerenciamento dos usuários de um sistema, tais como autenticação, adição e remoção dos mesmos, respectivamente através dos programas ulogin, adduser e rmuser. A finalidade aqui não é desenvolver um sistema complexo, mas apenas ilustrar didaticamente o uso das RPCs no ambiente Sun, mostrando como este pode ajudar o programador na tarefa de escrever aplicações distribuídas.

$\mathrm{Na}$ Figura 4.2, a seguir, as caixas sombreadas representam o código que o programador tem que fornecer. Obviamente, este inclui a aplicação cliente, os procedimentos servidores e também o arquivo de especificação da interface destes procedimentos remotos $(* . x)$.

Este arquivo, senha.x, é a entrada para o compilador rpcgen e a linguagem utilizada para a especificação da interface dos procedimentos é bastante semelhante à linguagem C. É preciso fornecer pelo menos um número para o programa servidor e, para cada procedimento remoto, os tipos de seus parâmetros, valor de retorno, um identificador, e ainda um número de versão. Após submetido à análise do rpcgen, este arquivo vai dar origem a quatro outros: os stubs cliente (senha_clnt.c, neste exemplo) e servidor (senha_svc.c), um arquivo de cabeçalho (senha.h) e, finalmente, um quarto arquivo (senha_xdr.c) para realizar a conversão dos tipos de quaisquer estruturas ou variáveis definidas em senha.x. Uma peculiaridade do Sun RPC é que as declarações contidas no arquivo de cabeçalho obrigam que as funções remotas sempre retornem um ponteiro e, para elas, é passado sempre o endereço dos seus argumentos. Essa característica torna necessário realizar algumas mudanças no código fonte da aplicação convencional, a não ser que se escrevam rotinas de interface para os procedimentos no cliente e no servidor [Com93; Cap. 22]. Outro aspecto é que, se for necessário passar mais de um parâmetro para um procedimento, estes deverão estar contidos em uma estrutura.

Todos estes arquivos são, então, compilados e ligados juntamente com o código fonte dos programas e a Biblioteca de RPC para gerar a aplicação distribuída. Feito isto, inicializa-se o servidor em uma máquina remota para que os clientes possam 
utilizar seus serviços. Quando o servidor é executado, este inicialmente cria um socket TCP ou UDP e faz um bind de qualquer porta local com o mesmo. Em seguida, chama a função $s v c_{-}$register(), da Biblioteca RPC, a fim de registrar seu número de programa, versão e numero de porta junto ao port mapper, ficando, então, na espera por uma solicitação de algum cliente. Todas estas ações são de responsabilidade do $s t u b$ servidor, sendo transparentes para o programador. O cliente, por sua vez, ao ser iniciado, usa a função clnt_create(), a qual contacta o sistema remoto e obtém, a partir do port mapper, o número de porta utilizado por um certo servidor. A partir daí, a interação cliente-servidor passa a ocorrer normalmente.

Fonte Procedimentos

Servidores

Prog.

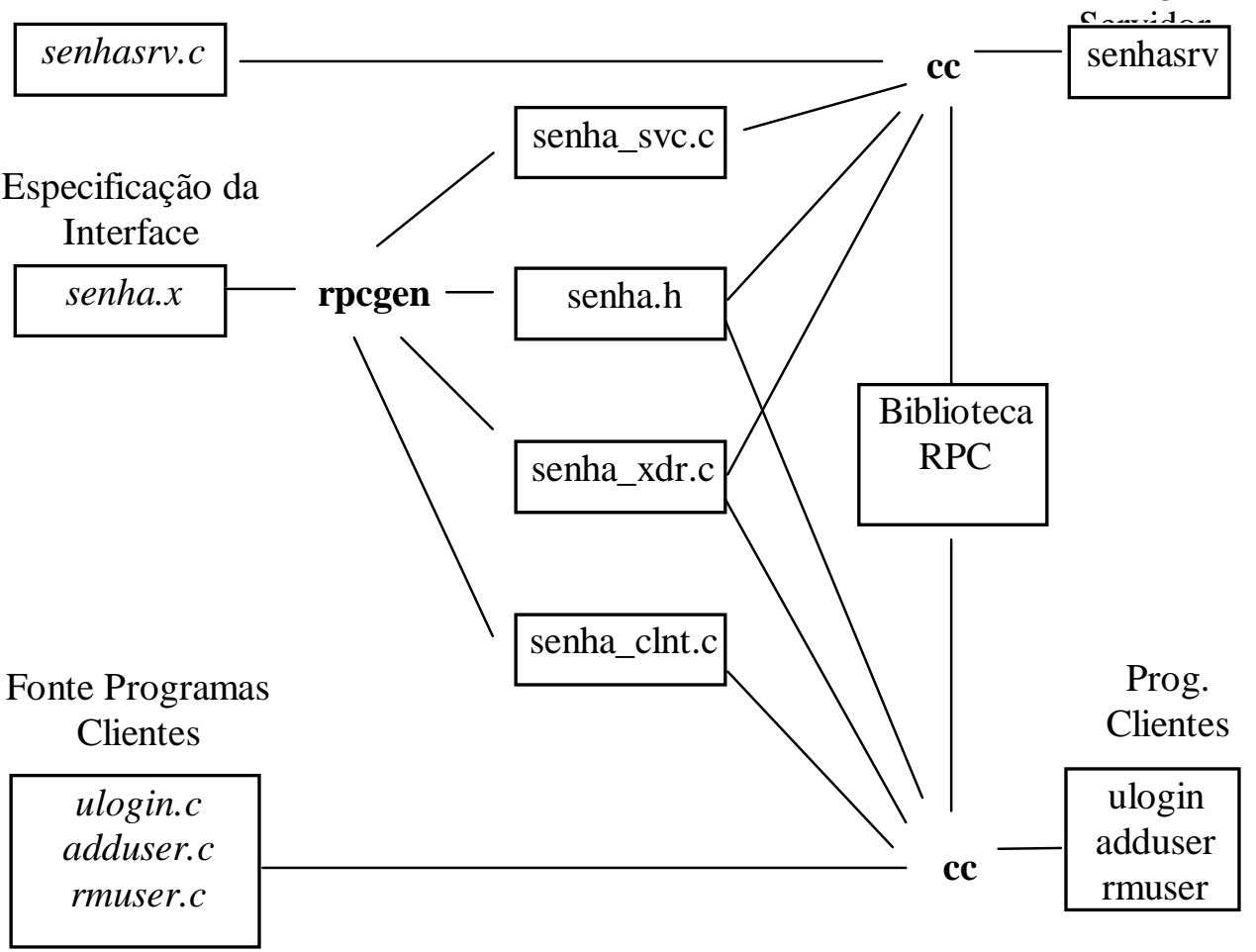

Fig. 4.2 - Arquivos envolvidos na geração de um programa Sun RPC

\subsubsection{Consderoçdes Fnds}

Pelo que foi visto, é possível concluir que o Sun RPC torna fácil a tarefa de implementar aplicações cliente-servidor, isto é, não exige que o programador tenha que se preocupar com os detalhes de comunicação através da rede. Praticamente, sua única preocupação adicional é prover o arquivo *.x, que é submetido ao rpcgen. Além 
disso, a existência de um arquivo com a definição da interface dos procedimentos, isola, de certa forma, as funções que o servidor disponibiliza aos seus clientes da implementação das mesmas, além de permitir um controle de versão, ou seja, possibilita que modificações nos procedimentos remotos sejam testadas, ao mesmo tempo em que se mantém o sistema em funcionamento com a versão antiga.

Um dos senões do sistema é a existência de um port mapper em cada máquina servidora, o que impede de se considerá-lo totalmente distribuído, já que o cliente tem que saber, pelo menos, que um certo serviço está disponível em uma certa máquina. Uma abordagem mais transparente seria possuir um serviço de binding global para o sistema (seção 3.5), que seria consultado toda vez que um cliente invocasse uma função remota. Assim, este não só esconderia do cliente onde sua aplicação está sendo realmente executada, mas também aumentaria a disponibilidade do sistema, no caso de falha de um servidor. Permitiria, ainda, no caso de haver serviços iguais implantados em mais de uma máquina, um melhor balanceamento da carga de trabalho entre os servidores.

\section{Ambiente HS-DOS}

O exemplo conhecido de um Sistema de RPC baseado no ambiente MS/PCDOS é o Gerador Automático de Stubs, projetado no LaSD (Laboratório de Sistemas Distribuídos), do ICMSC-USP, por Heli Nascimento, em sua dissertação de Mestrado [Nas95].

Neste sistema, a proposta inicial era produzir uma ferramenta de auxílio ao desenvolvimento das rotinas de comunicação entre as estações de trabalho e o servidor de processamento paralelo do LaSD, mas, ao final, evoluiu-se para uma ferramenta de auxílio à implementação de aplicações distribuídas de propósito geral.

A semântica utilizada para as RPCs é a At-Most-Once, na qual o cliente envia uma solicitação e aguarda pelo acknowledgement do servidor. Caso este não chegue dentro de um tempo pré-determinado, o cliente temporiza e reenvia a solicitação. $\mathrm{O}$ servidor, por sua vez, analisa o número de seqüência contido em cada mensagem a fim de determinar se um pedido já foi executado anteriormente, dessa forma evitando repetições desnecessárias ou até nocivas à integridade das informações. O número máximo de clientes que um servidor pode atender por vez são cinco.

O sistema de binding utilizado consiste em um arquivo que contém os nomes dos servidores e seus respectivos endereços. Assim, não é preciso colocar o endereço dentro dos programas, além de abrir caminho para uma futura implementação de um binder. 
Para utilizar o Sistema de RPC, o programador tem que fornecer a especificação da interface dos procedimentos remotos e quaisquer definições globais utilizadas pela aplicação, na IDL fornecida pelo sistema, cuja sintaxe é semelhante à da linguagem C. Em seguida, submete-se este arquivo à análise do Gerador de Stubs, o qual irá gerar os stubs cliente e servidor e um arquivo de cabeçalho a ser usado por ambos. Feito isto, é só fazer a ligação da aplicação propriamente dita com estes arquivos e gerar os módulos cliente e servidor. Observa-se, que, a exemplo do Sun RPC, aqui também o programador é isolado o máximo possível das particularidades da comunicação pela rede.

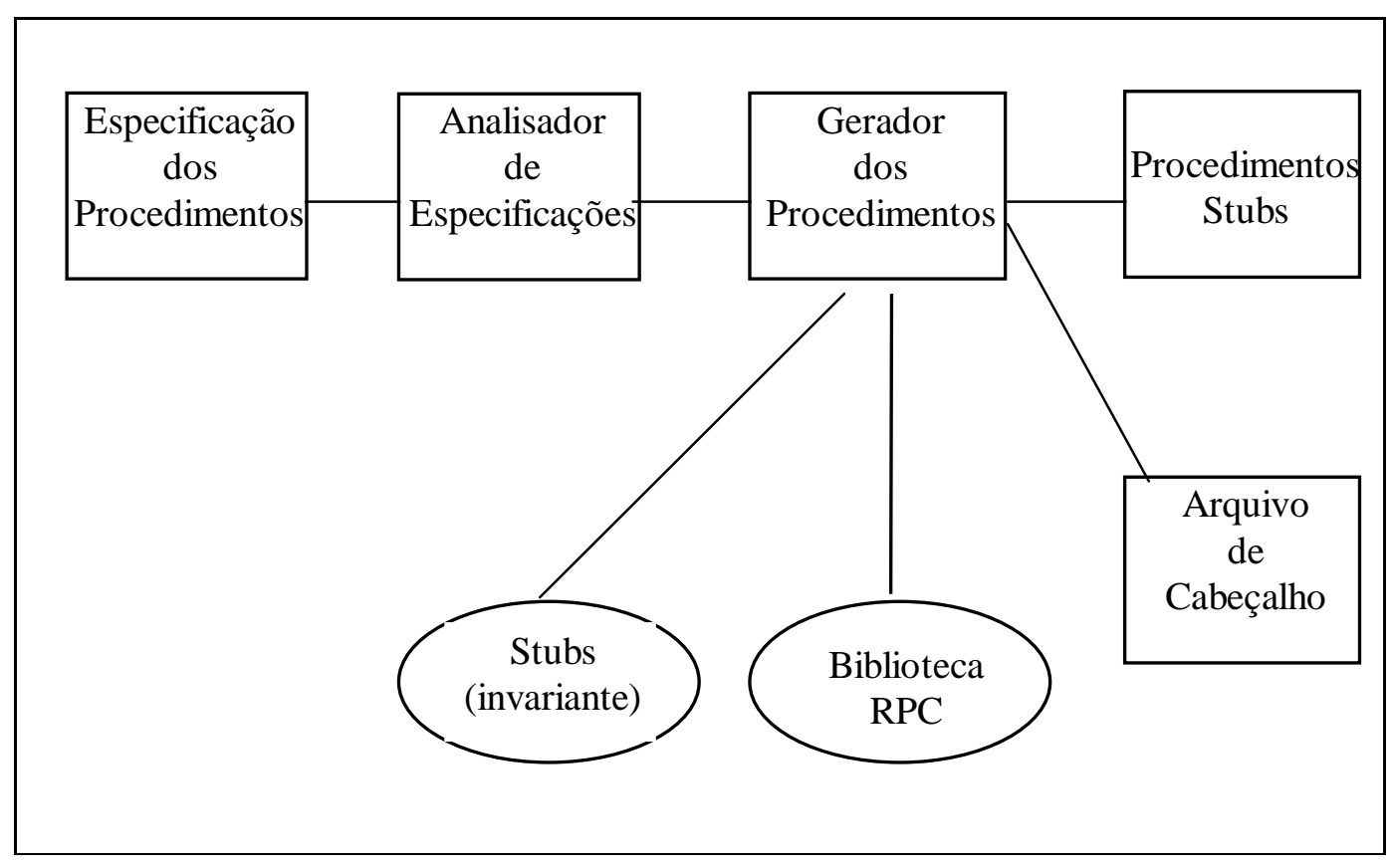

Fig. 4.3 - Estrutura do Gerador de Stubs

A figura 4.3 mostra a estrutura geral do Gerador de Stubs. O Analisador de Especificações recebe as definições escritas na IDL (parte variante), verifica sua correção léxica, sintática e semântica e gera um produto intermediário que será submetido ao Gerador dos Procedimentos. Este, por sua vez, a partir do resultado do Analisador, juntamente com a parte invariante dos stubs e a Biblioteca RPC, cria os procedimentos stubs e o arquivo de cabeçalho, que serão ligados com os programas fonte cliente e servidor.

\subsection{O Ambiente Windows}

Como não poderia deixar de ser, a família Microsoft Windows, já que pretende ser um padrão de fato não só para os usuários finais, mas também uma opção a ser 
seriamente considerada pelos desenvolvedores de software, teve a necessidade de incorporar a seu "arsenal" facilidades para a construção de aplicações cliente-servidor (distribuídas), uma vez que estas se tornam, cada vez mais, a realidade do mercado.

Assim, ao construir o Windows NT, a Microsoft decidiu que o mesmo deveria ser dotado de um serviço completo de RPC, do qual, inclusive, dependeria o próprio funcionamento deste sistema operacional. O RPC, então, é parte integrante do Windows NT e também do Windows 95, sendo fornecido juntamente com eles, da mesma forma que o suporte aos protocolos da família TCP/IP.

O Microsoft RPC baseia-se no DCE RPC. O DCE (Distributed Computing Environment), uma proposta da OSF (Open Software Foundation), consiste em um conjunto integrado de ferramentas e serviços, independentes do sistema operacional e da rede, que servem de auxílio ao desenvolvimento, uso e manutenção de aplicações distribuídas [Mil94]. Um dos objetivos principais do DCE é justamente permitir interoperabilidade e portabilidade das aplicações entre plataformas de hardware e software diversas, estejam os equipamentos conectados através de LANs ou WANs [Blo95]. O DCE reside entre as aplicações distribuídas e o sistema operacional e os serviços de rede, provendo facilidades como uma nomenclatura global para os objetos, um serviço de diretórios global, serviços de gerenciamento do sistema, gerenciamento de processos remotos, de threads, características de segurança, dentre outras. No âmbito desta monografia, o que é de interesse é o fato de que a peça fundamental para a comunicação, dentro do DCE, é justamente a tecnologia de RPCs [Mic95b], que permite que o sistema atinja a tão desejada transparência, tanto sob o ponto de vista dos usuários finais quanto dos programadores.

O DCE tem tido uma boa aceitação por parte dos usuários e desenvolvedores de software, tendo sido esta uma das razões que levou a Microsoft a se basear no DCE RPC para a construção do seu próprio sistema. O Windows NT contém um suporte completo ao MS RPC, em código de 32 bits, estando também sua implementação disponível em 16 bits para os ambientes MS-DOS e Windows 3.x, sendo que, nestes últimos, as aplicações podem funcionar apenas como clientes dos serviços, ao contrário das plataformas Windows NT e Windows 95, nas quais podem coexistir aplicações clientes e servidoras. O objetivo dessa difusão do RPC pela plataforma Windows é permitir que aplicações executando nesses ambientes possam se comunicar com servidores em ambientes UNIX tradicionais, como SunOS, IBM-AIX, HP-UX e outros, sendo isto possível porque todos usam o RPC como o mecanismo padrão para a troca de mensagens entre os processos, através da rede [Mic95c].

O DCE RPC, e, conseqüentemente, o MS RPC, não diferem muito do consagrado Sun RPC. Aqui, também, existe uma linguagem de definição de interface, com sintaxe semelhante à da linguagem $\mathrm{C}$, ocorrendo igualmente a geração de procedimentos stubs e arquivos de cabeçalho. O MS RPC apresenta algumas diferenças em relação ao DCE RPC, particularmente em relação a nomes de algumas 
funções da API e ordem dos parâmetros nas chamadas. Portanto, é fornecido um utilitário de conversão entre o DCE e o MS RPC, para aumentar a produtividade dos programadores. Em relação ao transporte de dados na rede, no MS RPC e DCE RPC, diferentemente do Sun RPC, não há um formato canônico único adotado pela rede; o que ocorre é que o receptor tem a responsabilidade de verificar se há necessidade ou não de conversão dos dados, conforme a máquina que enviou a mensagem [Blo92]. O emissor apenas envia os pacotes, sem maiores preocupações com seu formato.

O DCE RPC, assim como o MS RPC, não dá suporte a interconexões assíncronas, sendo que, no caso do DCE, essa limitação é resolvida pelo uso de threads [Blo95] e, no ambiente Windows, através da tecnologia ODBC (Open Database Connectivity), que permite a realização de consultas síncronas e assíncronas a bases de dados diversas [Mic95c].

Ambas as ferramentas não apresentam características de orientação a objetos, sendo um dos objetivos futuros disponibilizar aos usuários este tipo de funcionalidade. Também há planos de integrar ao MS RPC mecanismos de segurança ao modo do Kerberos [Cou94; Cap. 16]. Estas características deverão estar disponíveis a partir da liberação do Windows NT "Cairo" [Mic95a], que, por enquanto, é apenas uma promessa.

Portanto, como se pode ver, as chamadas remotas a procedimentos passaram, recentemente, a ser contempladas na família Windows, devido à necessidade de interconectividade e portabilidade em relação a outras plataformas. Entretanto, há algumas características desejáveis que não são ainda atendidas, particularmente RPCs assíncronos e orientação a objetos.

\subsection{Conclusōo}

Neste capítulo, foram vistas técnicas para a construção de aplicações distribuídas, abordando-se o projeto orientado à comunicação e o orientado à aplicação. Foram discutidas as dificuldades existentes e apresentaram-se algumas sugestões que podem servir de auxílio aos programadores que se iniciam nessa área. Mostrou-se também a importância das RPCs como ferramenta de aumento de produtividade no desenvolvimento das aplicações distribuídas. Discutiu-se, em seguida, sua implementação em três plataformas distintas: Sun, MS-DOS e Windows. No ambiente Sun, foi apresentado, dentre outras coisas, um exemplo de geração de uma aplicação simples, usando-se RPC. No ambiente MS-DOS, analisou-se a implementação feita no LaSD e, finalmente, concluiu-se com a implementação de RPCs na plataforma Windows, sendo destacados os pontos em que ainda há espaço para melhorias. 


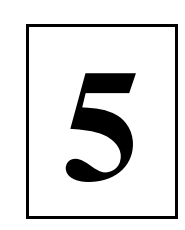

\section{ORPCw95 Análise e Desenvolvimento}

Neste capítulo, será apresentada inicialmente a arquitetura do mecanismo de RPCs desenvolvido, destacando-se suas características básicas. Inicialmente, será abordado o Gerador de Stubs e seus componentes principais. Em seguida, será dada atenção à Biblioteca RPC, sendo mostrados os passos seguidos na fase de análise e apresentada a especificação de cada classe e os relacionamentos entre elas. Finalmente, será discutido o Serviço de Binding do sistema.

\subsection{Introduç̄o}

O mecanismo de RPCs desenvolvido no presente trabalho, denominado ORPC $w 95$, tem como objetivo fornecer uma ferramenta para o desenvolvimento de aplicações distribuídas no ambiente Windows 95 (32 bits), procurando tornar esta tarefa mais simples, uma vez que, com o uso das chamadas remotas, os programadores podem se concentrar na aplicação que estão desenvolvendo e não nos detalhes de troca de mensagens entre os diferentes módulos da mesma, aumentando sua produtividade.

A abstração de RPCs já é amplamente utilizada em diferentes ambientes, alguns deles abordados no Capítulo 4, tendo se tornado virtualmente um padrão para o desenvolvimento de aplicações distribuídas com os mais diferentes propósitos. Nada mais justo, portanto, que se procure ter tal facilidade no ambiente Windows 95, particularmente uma ferramenta deste tipo, aberta a modificações e melhoramentos.

\section{Arquifetura do Sistema}


O mecanismo ORPCw95 é composto dos seguintes elementos: um Analisador de Especificações, o Gerador de Stubs, a Biblioteca RPC (RPC API) e um Serviço de Binding. Estes quatro elementos se combinam a fim de produzir a ferramenta de suporte à construção de aplicações distribuídas.

O Analisador de Especificações é o componente do sistema que recebe como entrada a especificação da interface dos procedimentos remotos, fornecida pelo programador em uma linguagem previamente definida (vide seção 3.2). Este módulo é responsável por validá-la léxica, sintática e semanticamente, conforme as restrições estabelecidas na gramática geradora da linguagem.

O produto do Analisador serve como entrada para o módulo seguinte, o Gerador de Stubs, o qual, juntamente com a parte invariante dos stubs e a biblioteca RPC, produz os stubs cliente e servidor e também um arquivo de cabeçalho com definições globais, os quais serão encadeados com os módulos cliente e servidor da aplicação em desenvolvimento. O Analisador de Especificações e o Gerador de Stubs constituem o que alguns autores denominam de Compilador de Interface do sistema de RPC [Blo92][Cou94].

Quanto à Biblioteca $R P C$, esta contém as funções que, de fato, permitem a troca de mensagens entre os diferentes componentes da aplicação distribuída. A utilização de uma biblioteca desse tipo libera o código dos stubs de tratar de detalhes específicos relacionados à comunicação, tornando-o de alto nível, o que implica em mais legibilidade e simplificação da fase de geração automática (seção 3.2.1).

Finalmente, existe um Serviço de Binding ativo em cada máquina, o qual contém um registro de todos os serviços disponíveis naquele equipamento, sendo consultado pelos clientes na fase inicial da RPC. O Binder (ou port mapper [Sun90]) faz o mapeamento entre os serviços executando no servidor e seus endereços.

\subsubsection{Caracterítllos Gords}

Pretende-se aqui analisar algumas das características básicas do mecanismo de RPCs desenvolvido.

\section{Semântica}

A semântica utilizada para a RPC é a at-least-once, a qual garante que cada procedimento será executado pelo menos uma vez, podendo, eventualmente, acontecer mais de uma execução, motivada principalmente por atrasos na transmissão das mensagens de solicitação de serviços pela rede. Esta semântica, utilizada em ambientes como Sun RPC [Cou94] e DCE RPC [Mil94], é de simples implementação e impõe uma sobrecarga menor na execução das chamadas remotas, além de garantir a execução das mesmas. Contudo, ao projetar a interface do servidor, é preciso tomar- 
se cuidado para que todos os procedimentos sejam idempotentes (seção 3.6.1), a fim de que repetições dos mesmos não corrompam a integridade dos dados. A ferramenta ORPCw95 também permite o estabelecimento de timeouts e número máximo de repetições para as chamadas remotas (seção 5.4.5).

\section{Orientação a Objetos}

Para o desenvolvimento da Biblioteca RPC, foi escolhido o paradigma de orientação a objetos. Com isso, pretendeu-se tornar este módulo de fácil manutenção e independente do protocolo utilizado para o transporte das mensagens. Assim, fica simples introduzir, por exemplo, suporte a novos protocolos de comunicação, além de características como diferentes semânticas da RPC, autenticação, tipos de dados complexos, conversão entre ambientes diferentes e outras.

\section{Código de 32 bits}

Todo o código da Biblioteca RPC, bem como o das aplicações distribuídas apresentadas posteriormente, foi escrito para o ambiente Windows 95, ou seja, em 32 bits, por ser esta uma das tendências atuais para o desenvolvimento de aplicações, tanto centralizadas quanto distribuídas.

\section{TCP/IP}

Para esta implementação, utilizou-se a família de protocolos TCP/IP, mais especificamente a API conhecida como Windows Sockets. A escolha do TCP/IP devese a sua ampla aceitação, atualmente, como protocolo de interconexão de máquinas em um ambiente distribuído, além da disponibilidade de interfaces de programação (APIs), como é o caso dos sockets.

Para concluir, a figura 5.1 mostra o relacionamento entre as aplicações distribuídas, a ferramenta ORPCw95, a pilha TCP/IP e as sete camadas do Modelo de Referência OSI. Os blocos com linhas pontilhadas representam módulos que poderão ser incorporados à ferramenta posteriormente.

\subsection{A Geraçāo Automático dos Stubs}

Um dos objetivos que se pretende alcançar ao projetar um mecanismo de RPCs é garantir que os programadores tenham que se preocupar o mínimo possível com a distribuição das aplicações, isto é, aspectos como o protocolo de interação entre clientes e servidores, formato das mensagens trocadas, protocolos de comunicação e outros devem ser de preocupação exclusiva do sistema de RPCs. 


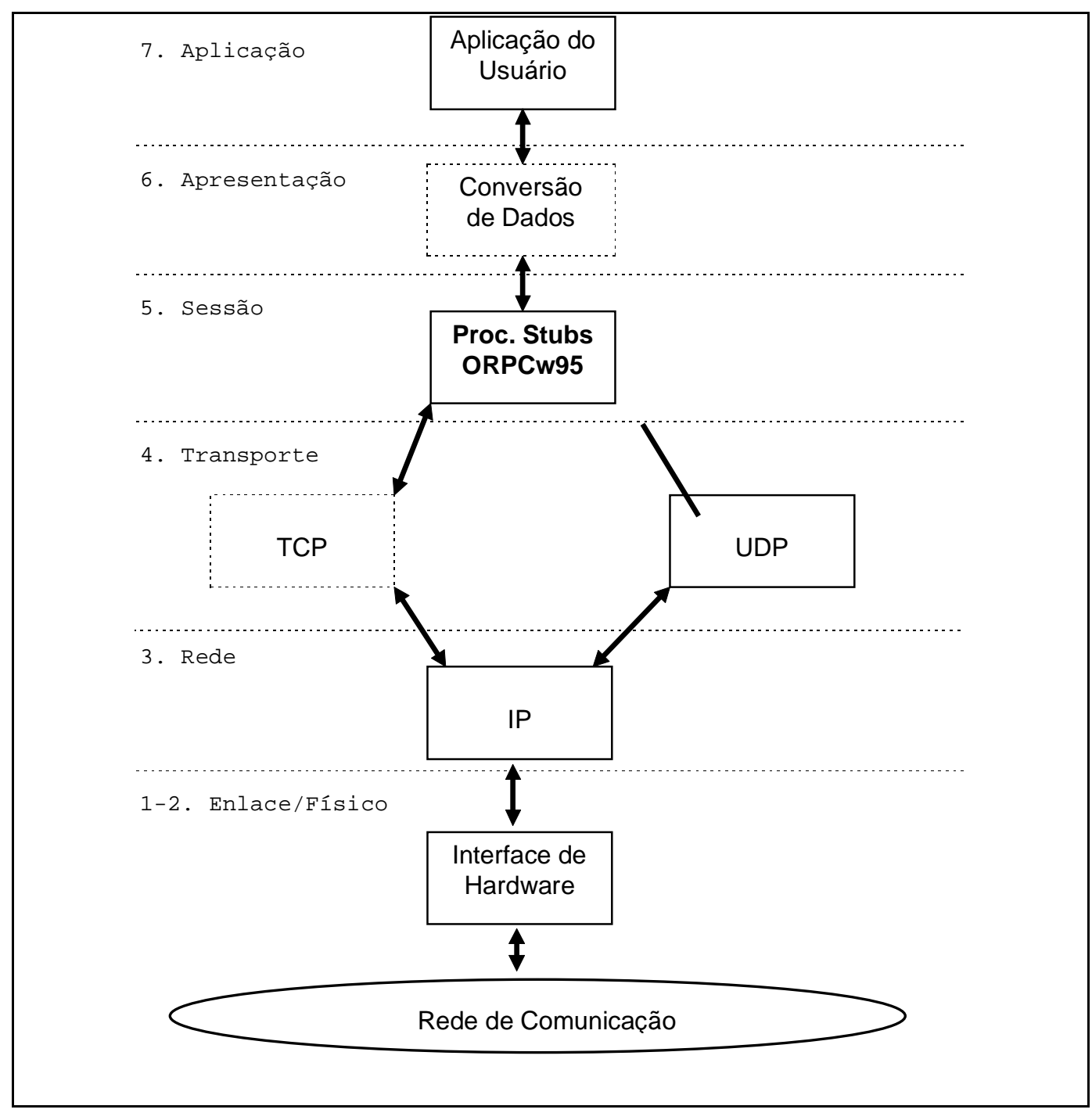

Fig. 5.1 - Relacionamento Aplicações x ORPCw95 x OSI

Para que se atinja tal objetivo, um dos elementos de fundamental importância é justamente a Geração Automática dos Stubs, a qual garantirá que a produção dos procedimentos stubs se dará de forma transparente aos programadores. Estes procedimentos, como se sabe, são os efetivamente responsáveis pela implementação do protocolo de interação entre clientes e servidores, contendo, em seu corpo, as rotinas para a comunicação. Ao stub cliente, cabe contactar o binder da máquina em que está localizado o serviço, obter o endereço deste, realizar a chamada remota e aguardar seu resultado. Já o stub servidor encarrega-se de registrar o(s) serviço(s) junto ao binder, aguardar as solicitações dos clientes, executar o procedimento servidor real e retornar os resultados.

Uma vez gerados os procedimentos, é necessário apenas encadeá-los com os respectivos programas cliente e servidor no lugar dos procedimentos reais. Como seu 
código fonte torna-se disponível, é possível realizar alguma otimização de código que se faça necessária (na prática, isto raramente ocorrerá).

\subsubsection{Estrutura do Gerador}

Para o desenvolvimento do Gerador da ferramenta em questão, utilizou-se, em parte, o código proveniente de um trabalho anterior [Nas95a], uma vez que as características de um gerador desse tipo pouco se alteram, com exceção do produto final (justamente o ponto em que foram feitas modificações). A figura 5.2 ilustra a estrutura do Gerador.

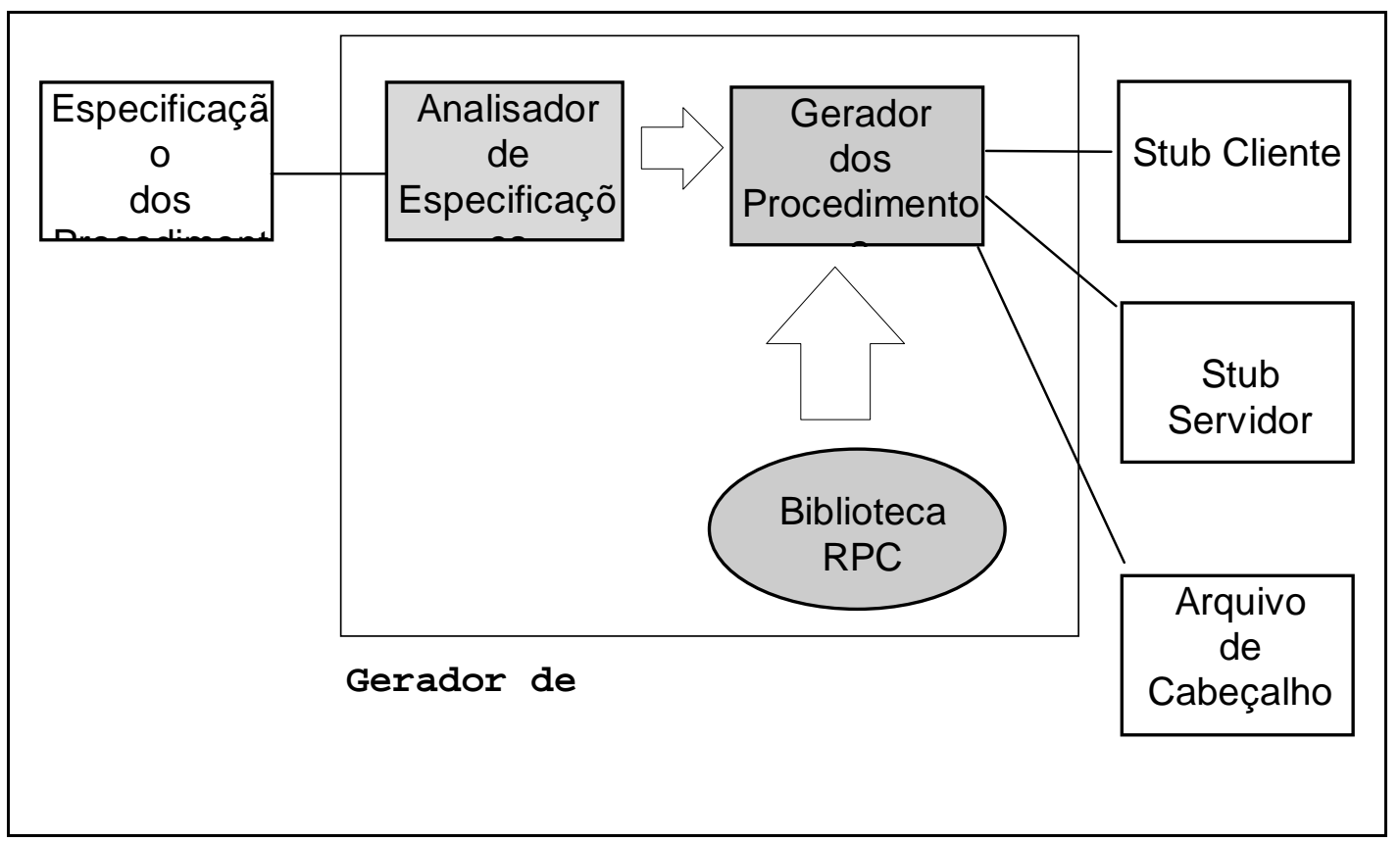

Fig. 5.2 - Diagrama do Gerador de Stubs (ORPCw95)

\section{A Linguagem de Interface}

Para a especificação da linguagem de interface, utilizou-se integralmente aquela já definida no trabalho de Nascimento [Nas95], a qual é bastante semelhante à especificação de protótipos de funções da linguagem "C", a exemplo de sistemas como Sun RPC [Blo92][Sun90] e DCE RPC [Mil94][Yag97]. Desse modo, o esforço de codificação da interface dos procedimentos torna-se mínimo, principalmente para sistemas sendo desenvolvidos em linguagem " $\mathrm{C}$ ".

Foi necessário, entretanto, introduzir elementos na linguagem de interface essenciais ao gerador, como é o caso dos modificadores in, out e inout, os quais informam se os parâmetros são apenas de entrada, só de saída ou de entrada/saída 
(tomando-se como referência o servidor). Assim, poupam-se transmissões desnecessárias de dados nas mensagens [Tan94], viabilizando-se também passagens de parâmetros "por referência" (na verdade, utiliza-se uma passagem do tipo copy/restore, conforme seção 3.4). A linguagem, entretanto, impõe algumas restrições, não permitindo a utilização de matrizes multidimensionais nem de estruturas encadeadas por ponteiros como parâmetros de funções. O exemplo a seguir (Fig. 5.3) mostra como seria a especificação dos procedimentos de um hipotético "servidor numérico". Note que a partícula in é assumida como default na ausência de outro modificador.

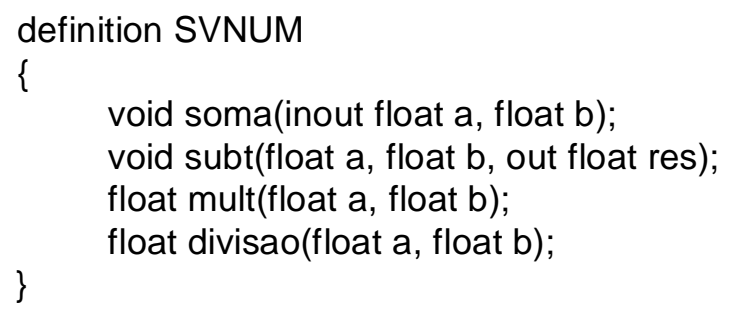

Fig. 5.3 - Exemplo de especificação de interface

Após definida a linguagem, a mesma foi formalizada utilizando-se a Forma Normal de Backus Estendida $\left(\mathrm{BNF}^{+}\right)$[Aho86], conforme mostrado no Apêndice A.

\section{O Gerador de Stubs}

O módulo gerador de stubs, na verdade, divide-se em duas partes: o analisador de especificações e o módulo gerador de procedimentos (Fig. 5.2). O primeiro recebe a especificação dos procedimentos remotos fornecida pelo programador, verifica sua validade no nível léxico, sintático e semântico e fornece como resultado um produto intermediário que é passado à segunda fase. O gerador de procedimentos, então, utilizando as funções da bliblioteca RPC, produz os stubs cliente e servidor e um arquivo de cabeçalho com definições globais.

Os dois módulos, portanto, foram implementados de forma independente, o que permitiu que, neste trabalho, fosse possível alterar o formato do produto final (os stubs), utilizando-se o mesmo analisador que havia sido definido anteriormente. Mais informações sobre a implementação do analisador e do gerador podem ser obtidas nas referências [Nas95]. No Capítulo 6, será feita uma análise detalhada do código dos stubs cliente e servidor.

\subsection{A Biblioteca RPC}


A Biblioteca RPC contém um conjunto de procedimentos para interação com a rede, sendo estes os responsáveis pela troca das mensagens entre cliente e servidor. Pode-se dizer, portanto, que esta biblioteca "encapsula" os detalhes e complexidades da comunicação, fornecendo aos níveis superiores uma interface (API) simples para programação. Os usuários da Biblioteca ORPCw95 são os procedimentos stubs e, eventualmente, algum programador mais especializado.

Na presente implementação, optou-se por escrever a Biblioteca RPC segundo o paradigma de orientação a objetos. Pretendeu-se, com isso, torná-la, assim como o código dos stubs, independente do protocolo de comunicação utilizado, além de facilitar a adição de novas características à mesma.

\subsubsection{Mótodo Utillzodo na Anälso}

Para a modelagem da Biblioteca ORPCw95, seguiu-se os princípios da Análise Orientada a Objetos (AOO) segundo a abordagem de Coad \& Yourdon [Coa92]. Estes autores propõem que o modelo de AOO seja dividido em cinco níveis:

a) Nível de assunto. Utilizado apenas em domínios de problemas bastante complexos, a fim de facilitar a leitura da representação gráfica do modelo, permitindo o particionamento do trabalho em pacotes.

b) Nível de Classe-\&-Objeto. Aqui o analista está preocupado em identificar as classes e objetos que compõem o sistema sendo estudado, aplicando os princípios de abstração e encapsulamento de dados. Após esta fase, tem-se uma visão geral dos elementos envolvidos no problema.

c) Nível de Estrutura. Neste nível, o foco das atenções volta-se para cada classe identificada anteriormente, a fim de apontar as semelhanças e diferenças existentes entre elas, particularmente a nível de herança. Podem-se encontrar estruturas do tipo Generalização-Especialização e Todo-Parte.

d) Nível de Atributo. Nesta etapa, procura-se identificar os atributos de cada classe, os quais correspondem às propriedades e características que precisam ser guardadas ou "lembradas" pelo sistema. Também é preciso encontrar quaisquer Conexões de Ocorrência existentes, que são uma espécie de mapeamento entre os objetos.

e) Nível de Serviço. Procura-se, neste ponto, encontrar os serviços existentes, os quais permitem a modificação dos atributos dos objetos, bem como a comunicação de um objeto com outro.

Os níveis acima representam as atividades globais que devem ser desempenhadas pelo analista, quais sejam: localização de classes-\&-objetos, 
identificação de estruturas, identificação de assuntos, definição de atributos e definição de serviços, partindo-se do maior para o menor nível de abstração. Não necessariamente esses níveis têm que ser percorridos em seqüência, alternando-se fases em que se trabalha em um nível mais alto com momentos em que se está preocupado com detalhes. Esses cinco níveis, na verdade, são como folhas transparentes que, sobrepostas umas às outras, apresentam gradativamente mais detalhes [Coa92].

Nas seções a seguir, tem-se uma descrição das classes definidas para a Biblioteca ORPCw95, bem como de seus relacionamentos.

\subsubsection{V/sáo Gord da Blbllobed}

Para proceder a modelagem do sistema em questão, inicialmente passou-se à fase de localização de classes-\&-objetos, tendo sido identificadas as seguintes classes e estruturas (vide Apêndice B):
a) RPCCall;
b) RPCEnlace;
c) RPCEnlaceCliente;
d) RPCEnlaceServiço;
e) RPCEnlaceINet;
f) RPCErro; e
g) RPCPMapper.

A classe $R P C C$ all relaciona-se com a chamada remota propriamente dita, em um alto nível, guardando as características principais da mesma e servindo como base para a classe seguinte na hierarquia, a RPCEnlace. Esta contém as características do enlace que precisa ser estabelecido entre cliente e servidor para que a RPC possa ocorrer, contendo vários serviços (ou métodos) para manipulação de mensagens. A partir desta classe, são derivadas duas outras: RPCEnlaceCliente $\mathrm{e}$ RPCEnlaceServiço, as quais apresentam, respectivamente, os métodos específicos do cliente e do servidor. Estas duas, finalmente, convergem na classe RPCEnlaceINet, responsável pela implementação da maioria dos métodos acima para a família de protocolos TCP/IP. As outras classes, portanto, podem ser ditas abstratas [Coa92][Boo94], já que seus métodos são funções virtuais (na nomenclatura do C++), sendo, de fato, implementados em um nível mais baixo da hierarquia.

Existe, ainda, a classe RPCErro, a qual, evidentemente, possui os códigos e as rotinas para tratamento de erros. Finalmente, a classe RPCPMapper, assim nomeada segundo a terminologia do Sun RPC [Sun90], trata da implementação do Serviço de Binding do sistema. 


\subsubsection{A Classo RPCCal}

O objetivo da classe RPCCall (Fig. 5.4) é representar a chamada remota no seu nível mais alto, armazenando suas informações mais relevantes, tais como: RPC síncrona ou assíncrona, localização do servidor atendendo a RPC, nome do serviço solicitado, valor de timeout da RPC, número máximo de repetições permitidas, dentre outras.

Esta classe serve de base para a classe RPCEnlace, sendo do tipo abstrata, uma vez que não se pode instanciar objetos do seu tipo. A relação entre RPCCall e RPCEnlace é representada por meio de uma Estrutura Todo-Parte (Apêndice B), pois pode-se dizer que toda chamada remota, para acontecer, precisa de pelo menos um enlace entre o cliente e o servidor.

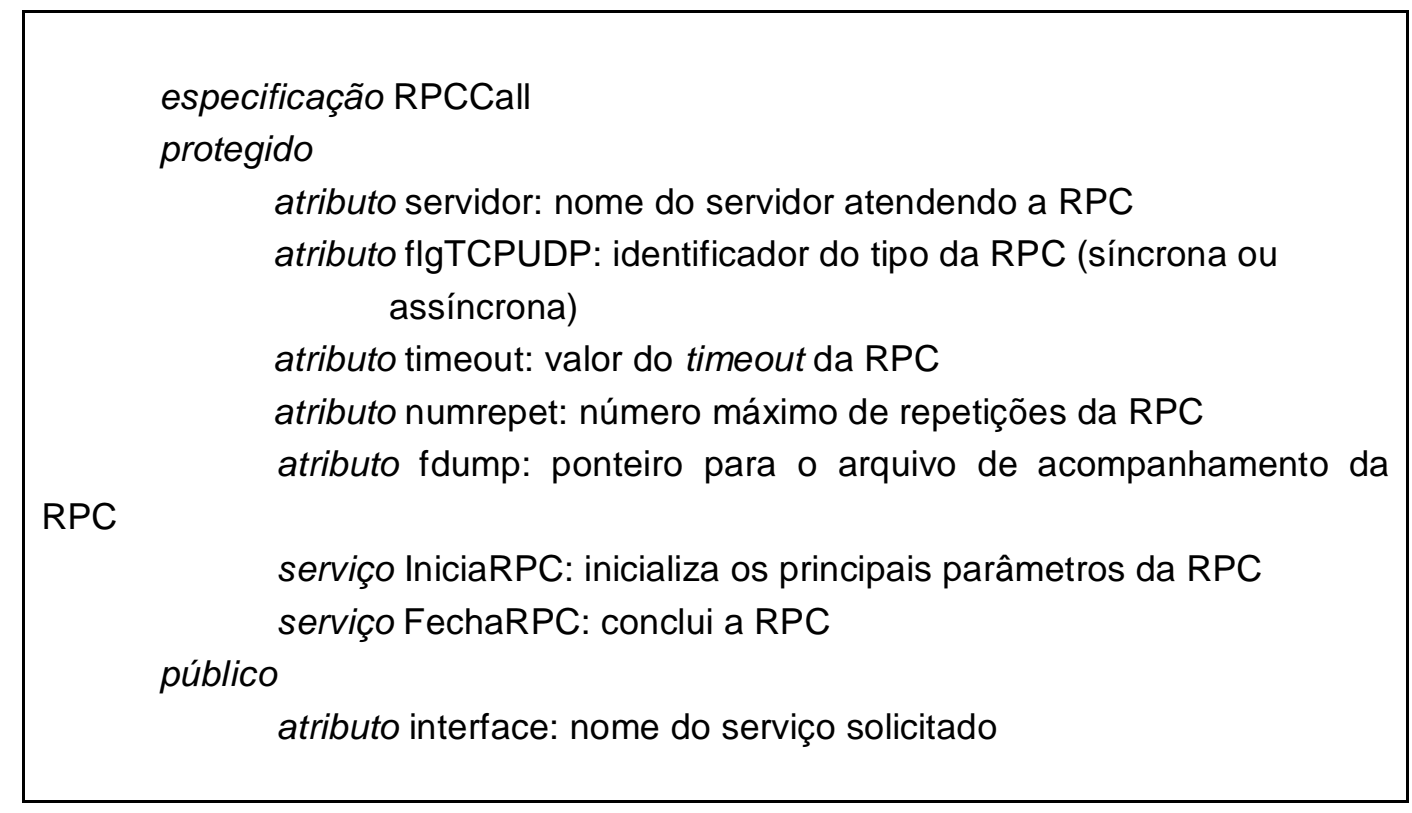

Fig. 5.4 - Especificação da classe RPCCall

Observe que a classe RPCCall contém os únicos métodos (serviços) que o usuário final da ferramenta ORPCw95 precisa conhecer, que são, justamente, IniciaRPC e FechaRPC, os quais são invocados no início e no final do programa cliente. Todos os demais métodos desta e das outras classes definidas são apenas para uso interno da biblioteca, não devendo ser objeto de preocupação dos programadores, o que contribui para a transparência do sistema.

\subsection{A Classo RPCEIloco}


A classe RPCEnlace (Fig. 5.5) representa o enlace que se estabelece entre o cliente e o servidor durante a realização de uma RPC. Esta armazena em seus atributos informações que dizem respeito ao enlace de uma maneira geral, tais como o conteúdo da mensagem e o tamanho da mesma, sem se preocupar com especificidades do cliente e do servidor, as quais serão tratadas no nível subseqüente da hierarquia. O mesmo se dá com seus métodos, que são responsáveis por tarefas como "montar" (marshall) e "desmontar" (unmarshall) a mensagem com os parâmetros e resultados da RPC; enviar e receber as mensagens; limpar o buffer de emissão ou recepção; tornar o enlace bloqueante ou não-bloquante, dentre outras funções.

especificação RPCEnlace

protegido

atributo msg: mensagem trocada entre cliente e servidor

atributo tam_msg: tamanho da mensagem

serviço LimpaMsg: limpa o conteúdo da mensagem

serviço MostraMsg: mostra o conteúdo da mensagem no monitor de

vídeo (utilizado para fins de depuração)

serviço ObtemTamanhoMsg: obtém o tamanho da mensagem

serviço MontaMsg: introduz um parâmetro na mensagem a ser enviada

serviço DesmontaMsg: retira o(s) resultado(s) da mensagem recebida

serviço IniciaEnlaceCli: inicia o estabelecimento do enlace no cliente serviço FechaEnlace: encerra o enlace estabelecido entre cliente e servidor

serviço SendMsg: envia uma mensagem

serviço RecvMsg: recebe uma mensagem (por default é bloqueante)

serviço TornaEnlaceAssinc: torna a primitiva RecvMsg não-

bloqueante

Fig. 5.5 - Especificação da classe RPCEnlace

Todos estes métodos foram implementados como funções virtuais puras do C++ [Mon94][Sch92][Str91], ou seja, neste nível da hierarquia não é escrita nenhuma linha de código; a implementação ocorrerá, de fato, no nível da classe RPCEnlaceINet. Com isso, consegue-se atingir um dos objetivos mencionados anteriormente quando se destacou a adoção do paradigma de orientação a objetos para a construção da Biblioteca RPC, que foi justamente torná-la independente do protocolo de comunicação utilizado para o transporte das mensagens. Como os métodos definidos são de propósito geral, vê-se que os mesmos não estão "presos" a 
nenhum tipo de protocolo em particular, nem a formatos de mensagens embutidos na Biblioteca.

\subsubsection{A Gasso R PCErlaceclonto}

A classe RPCEnlaceCliente (Fig. 5.6) contém atributos e serviços que são específicos do lado cliente da aplicação, como, por exemplo, rotinas para conectar (ou desconectar) o cliente ao servidor, para procurar um determinado serviço no Binder e assim por diante. Portanto, sua relação com a classe RPCEnlace é do tipo Generalização-Especialização.

especificação RPCEnlaceCliente

protegido

serviço MontaHeaderMsg: monta o cabeçalho das mensagens RPC

serviço ProcuraSvc: solicita ao Binder que informe sobre a

existência de um determinado serviço em uma máquina e

qual seu endereço

serviço DumpPMap: solicita ao Binder que liste todos os serviços

nele registrados (utilizado para fins de depuração)

público

atributo prim_vez: indica se é a primeira vez que uma RPC está

sendo executada, evitando consultas desnecessárias ao

Binder.

serviço BindCli: toma as ações necessárias para dar início à RPC

serviço UnBindCli: desconecta o cliente do servidor, finalizando a

RPC

serviço Call: envia a mensagem de solicitação de serviço e aguarda

seu resultado

Fig. 5.6 - Especificação da classe RPCEnlaceCliente

Os métodos desta classe são utilizados principalmente pelos procedimentos stubs, particularmente os métodos públicos BindCli, Call e UnBindCli. O método BindCli toma as ações necessárias para contactar o servidor, dando início à RPC; em seguida, o método Call encarrega-se de enviar a mensagem contendo a solicitação do serviço e aguardar seu resultado; finalmente, UnBindCli toma as providências necessárias para fechar o enlace entre o cliente e o servidor. Esses métodos são implementados utilizando-se somente os métodos protegidos da própria classe e alguns outros métodos definidos na classe RPCEnlace, conseguindo-se, assim, uma total independência em relação ao protocolo de comunicação utilizado. Os métodos protegidos, por sua vez, encarregam-se de montar o cabeçalho das mensagens RPC e 
de consultar o Binder sobre a disponibilidade de um determinado serviço em uma máquina.

\section{Mensagens RPC}

As mensagens enviadas pelo cliente ao servidor obedecem a um formato prédefinido, conforme mostrado na figura 5.7. O nome do serviço identifica qual serviço (ou interface) se deseja solicitar e deve corresponder a alguma das interfaces registradas no Binder da máquina servidora. Cada procedimento contido em uma determinada interface é identificado por um número inteiro, produzido automaticamente durante a geração dos stubs, que também deve ser informado na mensagem. Finalmente, o número de seqüência abre a possibilidade de uma futura inclusão de uma semântica at-most-once no mecanismo ORPCw95.

\begin{tabular}{|c|c|c|c|}
\hline $\begin{array}{c}\text { Tamanho da } \\
\text { Mensagem }\end{array}$ & $\begin{array}{c}\text { Número de } \\
\text { Seqüência }\end{array}$ & $\begin{array}{c}\text { Nome do Serviço } \\
\text { (Interface) }\end{array}$ & $\begin{array}{c}\text { Número do } \\
\text { Procedimento }\end{array}$ \\
\hline
\end{tabular}

Fig. 5.7 - Formato das mensagens RPC

\section{Tratamento de Timeouts}

O presente mecanismo de RPCs estabelece um tempo máximo de espera para que cada chamada remota se complete (timeout). Caso o cliente não receba o resultado da RPC no limite estipulado (o valor default são dez milissegundos), então a RPC será repetida, no máximo, mais 500 vezes. Se, após essas tentativas, o cliente ainda não tiver obtido uma resposta do servidor, então ocorrerá uma condição de erro prevista na classe RPCErro (seção 5.4.8). Os valores de timeout e número máximo de repetições podem ser ajustados pelo usuário da ferramenta ORPCw95.

Com o uso dessa estratégia, garante-se que a RPC será executada pelo menos uma vez, conforme as regras da semântica at-least-once e, desde que todos os procedimentos no servidor sejam idempotentes, não há problemas se eventualmente ocorrer repetição de uma ou outra chamada remota.

\subsection{A Classo RPCE-Iacoserviço}

A classe RPCEnlaceServiço (Fig. 5.8) corresponde à especialização da classe RPCEnlace para as atribuições do servidor. Seus métodos são responsáveis por tarefas como preparar o servidor para receber as solicitações dos clientes, desmontar o cabeçalho das mensagens que chegam, registrar a interface do servidor no Binder, removê-la quando o servidor deixar de funcionar e assim por diante. Da mesma forma que na classe anterior, os métodos aqui também se dividem em públicos e protegidos, 
sendo os do primeiro tipo utilizados diretamente no código dos stubs e implementados apenas com os métodos protegidos, a fim de atingir as vantagens já mencionadas na seção 5.4.5.

O método público BindSrv toma as ações necessárias para que o serviço possa iniciar o atendimento aos clientes, como, por exemplo, registrar sua interface (ou seja, o conjunto de procedimentos que oferece) junto ao Binder e, então, aguardar a chegada das mensagens. Por sua vez, UnBindSrv entra em ação quando o serviço vai deixar de funcionar, removendo a interface que tinha sido registrada no Binder e encerrando o enlace estabelecido. Vale acrescentar que os métodos protegidos da presente classe, assim como os da anterior, são funções virtuais puras, sendo implementados na classe RPCEnlaceINet. Desse modo, RPCEnlaceServiço, como as demais classes descritas até agora, é uma classe abstrata, não se podendo instanciar objetos do seu tipo.

especificação RPCEnlaceServiço

protegido

serviço DesmontaHeaderMsg: retira os dados do cabeçalho das mensagens

serviço IniciaEnlaceSrv: inicia o estabelecimento do enlace no servidor

serviço RegistraSvc: registra a interface do serviço no Binder serviço RemoveSvc: remove a interface registrada no Binder público

serviço BindSrv: toma as ações necessárias para inicializar o serviço serviço UnBindSrv: finaliza o serviço que está sendo oferecido

Fig. 5.8 - Especificação da classe RPCEnlaceServiço

\subsubsection{A Classo R PCEIccolNot}

A classe RPCEnlaceINet (Fig. 5.9) é a de nível mais baixo na hierarquia, sendo portanto responsável por implementar os métodos das classes acima para uma determinada família de protocolos; no presente caso, foram escolhidos os protocolos TCP/IP [Com91][Hun92][Tan94], mais especificamente o UDP, se bem que no código fonte já tenha sido deixado espaço para a introdução do protocolo TCP, o qual se faz necessário caso se deseje dar suporte a interconexões assíncronas. 


protegido
atributo sockfd: descritor do socket
atributo end_loc: endereço local
serviço CriaSocket: cria um socket
serviço BindSocket: faz o bind do socket
público:
atributo tam_end: tamanho do endereço
atributo end_orig: endereço de origem da mensagem
atributo end_dest: endereço de destino da mensagem
serviço RPCEnlaceINet: construtor da classe
serviço IniciaRPC: implementação do método definido numa classe
$\quad$ superior (idem para o seguintes)
serviço FechaRPC
serviço LimpaMsg
serviço MostraMsg
serviço ObtemTamanhoMsg
serviço MontaMsg
serviço DesmontaMsg
serviço MontaHeaderMsg
serviço DesmontaHeaderMsg
serviço IniciaEnlaceCli
serviço IniciaEnlaceSrv
serviço FechaEnlace
serviço SendMsg
serviço RecvMsg
serviço TornaEnlaceAssinc
serviço ProcuraSvc
serviço RegistraSvc
serviço RemoveSvc
serviço DumpPMap

Fig. 5.9 - Especificação da classe RPCEnlaceINet

Esta classe é derivada a partir de uma herança múltipla ou entrelaçamento [Coa92] das classes RPCEnlaceCliente e RPCEnlaceServiço, contendo um conjunto de métodos protegidos, que tratam de aspectos próprios do TCP/IP e um conjunto de métodos públicos, os quais implementam as funções virtuais das classes superiores para a plataforma escolhida. É nesta classe, portanto, que se devem fazer alterações caso se deseje dar suporte a outros protocolos de comunicação, tais como: IPX/SPX [Nie95] ou NetBEUI [Mic95d], podendo-se, inclusive, lançar mão de APIs já prontas, como é o caso dos Windows Sockets [Bon96]. É a classe RPCEnlaceINet que será 
instanciada nos programas feitos pelos usuários da ferramenta, para que se possam chamar os métodos de início e fim da RPC, conforme explicado na seção 5.4.3.

\subsubsection{A Classo RPCETo}

Esta é a classe responsável pelo tratamento de erros, tendo sido os mesmos agrupados em diferentes categorias, tais como: erros relativos à API Windows Sockets, ao transporte das mensagens, à RPC propriamente dita e ao Binder (vide Apêndice C). Foram definidos também dois métodos: um para obter a descrição do erro, dado seu código e outro para mostrar a mensagem de erro ao usuário, os quais podem ser invocados a partir de qualquer nível na hierarquia de classes. Veja na figura a seguir a especificação da classe RPCErro.

especificação RPCErro

público

atributo CodErro: enumeração que contém os códigos de erro prédefinidos

serviço ObtemErro: obtém a descrição do erro a partir de seu código

serviço MsgErro: mostra a mensagem de erro ao usuário, com

interface MS-DOS ou Windows

Fig. 5.10 - Especificação da classe RPCErro

\subsection{Serviço de Binding}

Para que um programa cliente possa iniciar a execução de uma RPC, ele precisa primeiramente conhecer a localização do servidor e também saber como contactar um procedimento naquele servidor. Uma maneira simples de conseguir isso (seção 3.5) é colocar o endereço do servidor diretamente no programa cliente ou fazer com que este o leia de um arquivo. Ambas as soluções não são flexíveis e exigem que o programador conheça as especificidades da ferramenta de RPCs. Por essa razão, a maioria dos sistemas que dão suporte a chamadas remotas preferem utilizar um Serviço de Binding, o qual é responsável por registrar todos os serviços (isto é, os procedimentos remotos) que estejam disponíveis em um determinado sistema, juntamente com sua localização. 
O serviço de binding, às vezes chamado de Binder ou Port Mapper [Sun90], é, na verdade, um servidor consultado pelos clientes a fim de descobrir o endereço do procedimento invocado, armazenando-o para chamadas futuras. Esta consulta geralmente precisa ser feita uma vez, no início de uma sessão de RPCs. Os servidores, por sua vez, ao iniciarem seu funcionamento, registram suas interfaces junto ao Binder, para que os clientes possam localizá-los. Quando necessitam interromper o serviço, uma das ações tomadas é justamente retirar os serviços registrados no Binder, para evitar que este contenha informações desatualizadas.

\subsubsection{Característlecs}

A ferramenta ORPCw95 também contempla um Serviço de Binding, que apresenta as seguintes características:

a) Existe um Binder por máquina, o qual armazena informações sobre todos os procedimentos executando naquele equipamento;

b) Utiliza o protocolo UDP para realizar a comunicação, recebendo e enviando mensagens através de uma porta pré-definida e conhecida por todos (porta número 1111);

c) Possibilita o registro de interfaces pelos servidores, sendo que cada interface corresponde a um conjunto de procedimentos inter-relacionados;

d) Possui código orientado a objetos, com o objetivo de facilitar futuras modificações;

e) Faz uso dos métodos da Biblioteca RPC para interação com seus clientes, o que torna sua implementação independente do protocolo de comunicação utilizado.

\subsubsection{A Classo RPCPMapper}

Para a implementação do Binder do sistema, foi definida uma classe denominada RPCPMapper, a qual contém todos os elementos necessários ao funcionamento do serviço de binding. Um objeto do tipo RPCPMapper mantém uma lista encadeada simples em que cada nó guarda informações relativas a uma interface oferecida por um servidor, tais como (fig. 5.11): o nome da interface (ou serviço), conhecido pelo programador; o protocolo utilizado para a comunicação (na implementação atual, o UDP) e a porta em que serão recebidas as mensagens de solicitação de serviços. Observe que não é necessário armazenar o endereço da máquina em que está localizado o serviço, pois, já que existe um Binder por máquina, o endereço da máquina é o próprio endereço do Binder. 


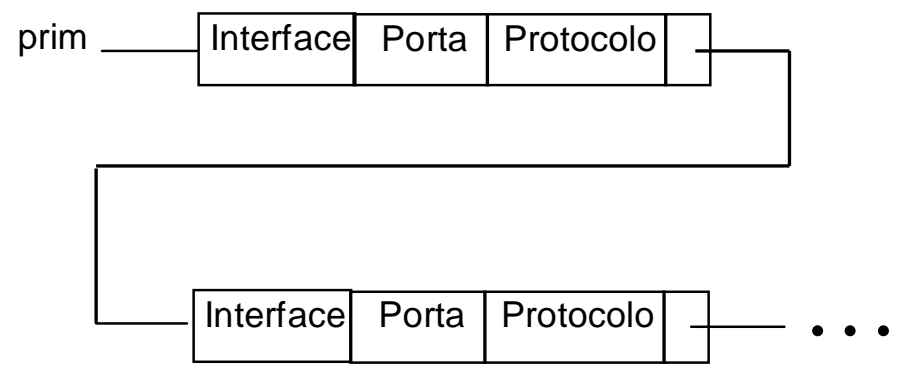

Fig. 5.11 - A lista encadeada mantida pelo Binder

Para a implementação da classe RPCPMapper, foi definido um conjunto de métodos públicos que facilita o gerenciamento da lista de serviços pelo Binder, conforme mostrado na figura 5.11. Cada máquina que esteja oferecendo serviços por meio da ferramenta ORPCw95 deve estar executando uma versão do Binder, o qual se responsabiliza também pelo tratamento de erros, tais como: nomes de interfaces duplicados, solicitação de informações sobre interfaces não registradas, "estouro" da lista encadeada, dentre outros (Apêndice C).

especificação RPCPMapper

privado

atributo prim: ponteiro para o início da lista de serviços (ou interfaces)

atributo tot_serv: número de serviços registrados

serviço ObtemNo: cria um novo nó da lista para inserir um serviço público

serviço RPCPMapper: construtor da classe

serviço Insere: insere um novo serviço na lista

serviço Remove: remove um serviço da lista

serviço Localiza: verifica se um determinado serviço está registrado

serviço Dump: mostra todos os serviços registrados

Fig. 5.12 - Especificação da classe RPCPMapper

\subsubsection{Intercçäo entro Cllentos o Servidoros}

Agora que já foi analisado o serviço de binding, é possível mostrar como se dá a interação entre clientes e servidores quando se utiliza a ferramenta ORPCw95 para a realização de chamadas remotas (fig. 5.13). 


\section{Visão do Cliente}

Quanto à aplicação cliente, o passo inicial tomado, quando da realização da primeira RPC de uma série, é contactar o Binder a fim de descobrir se o serviço solicitado está executando no servidor. Para tanto, utiliza-se o método BindCli, definido na classe RPCEnlaceCliente. Se o serviço for encontrado, é retornado ao cliente o número da porta onde o serviço está executando, para que aquele, em seguida, possa efetivamente realizar a chamada através do método Call, o qual envia a mensagem RPC ao servidor e fica aguardando o retorno da mesma.

Uma vez que a RPC tenha sido concluída com sucesso, resta ao cliente terminar sua execução ou, como é mais comum, realizar outras chamadas para o mesmo serviço. Neste caso, não é preciso consultar novamente o Binder, pois o cliente guarda o número da porta obtido anteriomente e o utiliza nas chamadas futuras. Caso o serviço seja retirado de funcionamento, o método BindCli retorna com um condição de erro informando que o serviço não está mais registrado no Binder e o programa cliente pode, então, tomar as ações cabíveis.

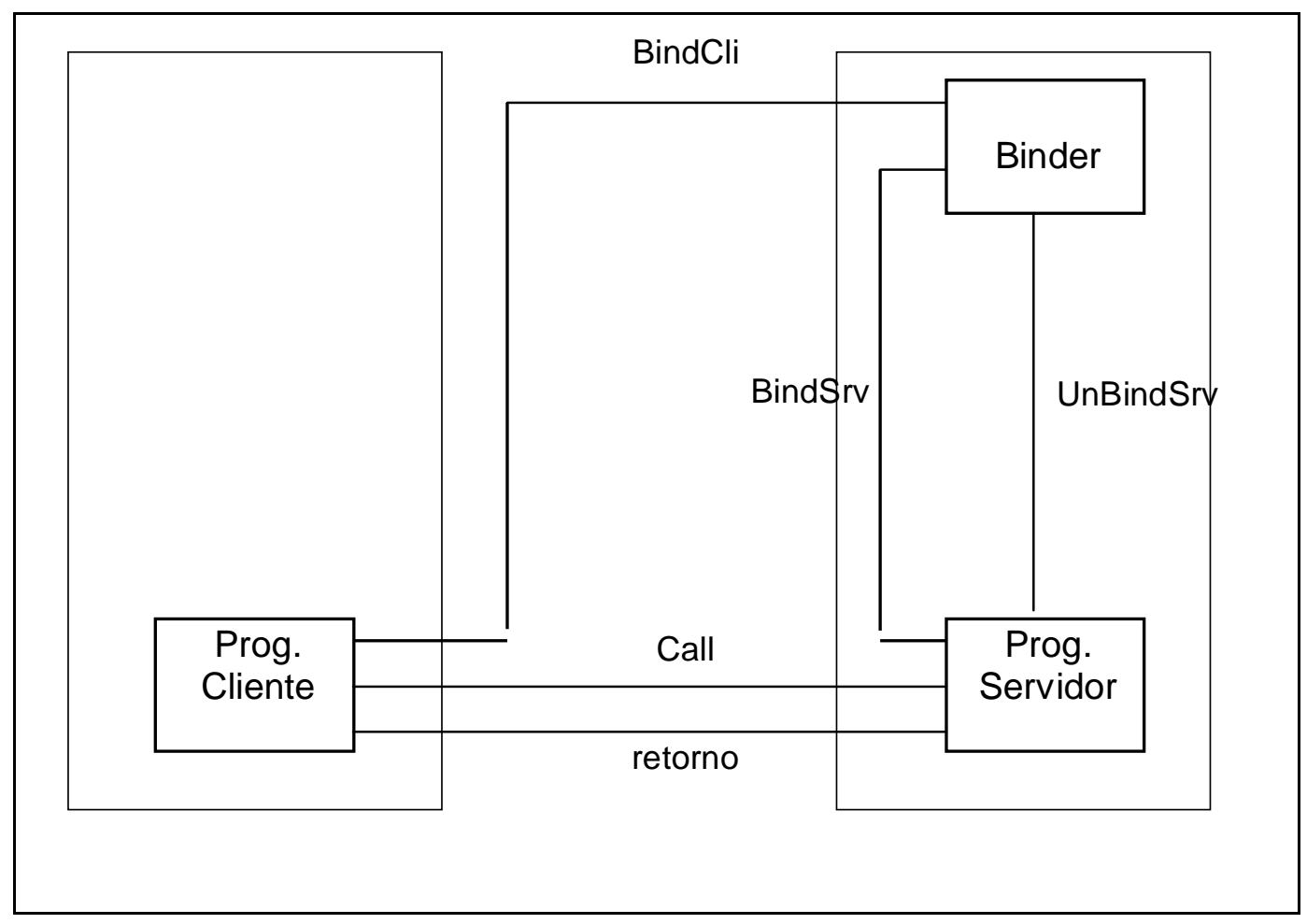

Fig. 5.13 - Interação Cliente x Servidor

\section{Visão do Servidor}


O programa servidor, ao iniciar sua execução, tem como primeira tarefa registrar a interface do serviço oferecido junto ao Binder, a qual, na verdade, é um nome que se relaciona com um conjunto de procedimentos, cada um deles identificado por um número seqüencial utilizado internamente. A figura 5.14 mostra o formato das mensagens enviadas ao Binder.

\begin{tabular}{|c|c|c|c|}
\hline $\begin{array}{c}\text { Código da } \\
\text { Operação }\end{array}$ & $\begin{array}{c}\text { Nome da } \\
\text { Interface }\end{array}$ & $\begin{array}{c}\text { Número da } \\
\text { Porta }\end{array}$ & $\begin{array}{c}\text { Identificação } \\
\text { do Protocolo }\end{array}$ \\
\hline
\end{tabular}

Fig. 5.14 - Formato das mensagens enviadas ao Binder

Para registrar o serviço, o programa servidor utiliza o método BindSrv, definido na classe RPCEnlaceServiço; feito isto, resta-lhe aguardar pela chegada das solicitações dos clientes. A cada solicitação recebida, retira, da mensagem RPC, o nome da interface solicitada e o número do procedimento chamado. Se tudo estiver correto, faz a chamada local ao procedimento e, após seu retorno, envia a mensagem com os resultados ao cliente. Quando o programa servidor deixa de funcionar, este deve remover a interface registrada no Binder, utilizando o método UnBindSrv.

Embora não se tenha dito explicitamente, todas as ações do cliente e do servidor a que se fez referência acima são de responsabilidade exclusiva dos procedimentos stubs, cujo código, como já foi visto, é gerado automaticamente. Portanto, toda esta interação entre cliente e servidor se dá de maneira transparente ao programador e ao usuário final da aplicação, os quais só serão informados do que está acontecendo na eventualidade de ocorrer algum erro.

\subsubsection{Facllldado do Manutonçào}

Como se pode ver pela descrição do serviço de binding, o mesmo foi projetado de modo a permitir modificações futuras sem que isso cause um grande impacto no código dos procedimentos stubs ou na implementação dos métodos da Biblioteca RPC.

Pode-se, por exemplo, incluir números de versões de procedimentos entre as informações que são enviadas ao Binder. Para, tanto, basta incluir mais um campo na mensagem e modificar a definição dos nós da lista encadeada. Caso a ferramenta ORPCw95 venha a utilizar outros protocolos para comunicação, nenhuma alteração se faz necessária no código do Binder ou dos procedimentos stubs, pois esta se daria no nível dos métodos protegidos das classes RPCEnlace e RPCEnlaceCliente/Serviço. Da mesma forma, é possível converter o serviço de binding atual, em que existe um servidor por máquina, para um sistema de Binder único ou com vários binders trabalhando em conjunto; a dificuldade, neste caso, seria como garantir a 
confiabilidade deste Binder central, no primeiro caso, ou a consistência das informações mantidas pelos diversos binders, no segundo.

\subsection{Conclusōo}

Aqui apresentou-se de maneira detalhada o mecanismo de RPCs implementado no presente trabalho, ressaltando-se suas características mais importantes e as principais decisões tomadas na fase de projeto da ferramenta. Abordou-se o Gerador de Stubs e a Biblioteca RPC, tendo sido mostrada a estrutura das classes implementadas, bem como a hierarquia estabelecida entre as mesmas. Para concluir, foi apresentado o Serviço de Binding do sistema, destacando-se sua implementação e a interação com os clientes e servidores. 


\section{ORPCw 95}

\section{Desenvolvimento de Aplicações}

Neste Capítulo, serão apresentadas algumas aplicações distribuídas construídas com o uso da ferramenta ORPCw95, sendo abordados aspectos como o desenvolvimento de um programa mínimo e apresentadas orientações gerais para o desenvolvimento de aplicações distribuídas no ambiente Windows, com a utilização da ferramenta. Será feita, também, uma análise do desempenho de uma aplicação em duas situações: utilizando-se apenas Windows Sockets para comunicação e empregando-se a ferramenta de RPCs.

\subsection{Introduçcio}

A fim de validar a ferramenta desenvolvida, foram construídas aplicações que procuraram explorar diferentes aspectos da mesma, como a utilização de tipos de dados diversos, processamento numérico e de strings, tratamento de erros, dentre outros. As aplicações escolhidas foram uma calculadora, um analisador de desempenho e um servidor de arquivos simples.

No desenvolvimento das aplicações, foram seguidas as orientações apresentadas no Capítulo 4, atentando-se para a "interferência" da ferramenta ORPCw95 no processo de desenvolvimento a fim de estimar o ganho de produtividade que é possível alcançar com a sua utilização. 


\subsection{A Cakuladora Hexadecimal}

A Calculadora Hexadecimal é uma aplicação bastante simples e, na verdade, não faria sentido desenvolvê-la usando RPCs. A razão de sua implementação deve-se ao fato de que, por sua simplicidade, a calculadora baseada em RPCs torna possível evidenciar o uso da ferramenta ORPCw95, destacando os pontos onde é necessário modificar o programa Windows e permitindo, inclusive, que se possa conceber o esqueleto de um programa mínimo (seção 6.5.1) que utilize a ferramenta.

A calculadora permite a realização de várias operações sobre números hexadecimais, tanto aritméticas quanto lógicas, além de rotações dos bits, sendo composta de um módulo cliente com interface Windows e de um módulo servidor que executa as operações solicitadas pelo usuário (fig. 6.1). No módulo cliente, são fornecidos os valores e solicitada a operação desejada e, a cada vez que for pressionada uma tecla de operação ou o sinal de igualdade, é iniciada uma RPC que vai concretizar a realização da operação pelo servidor.

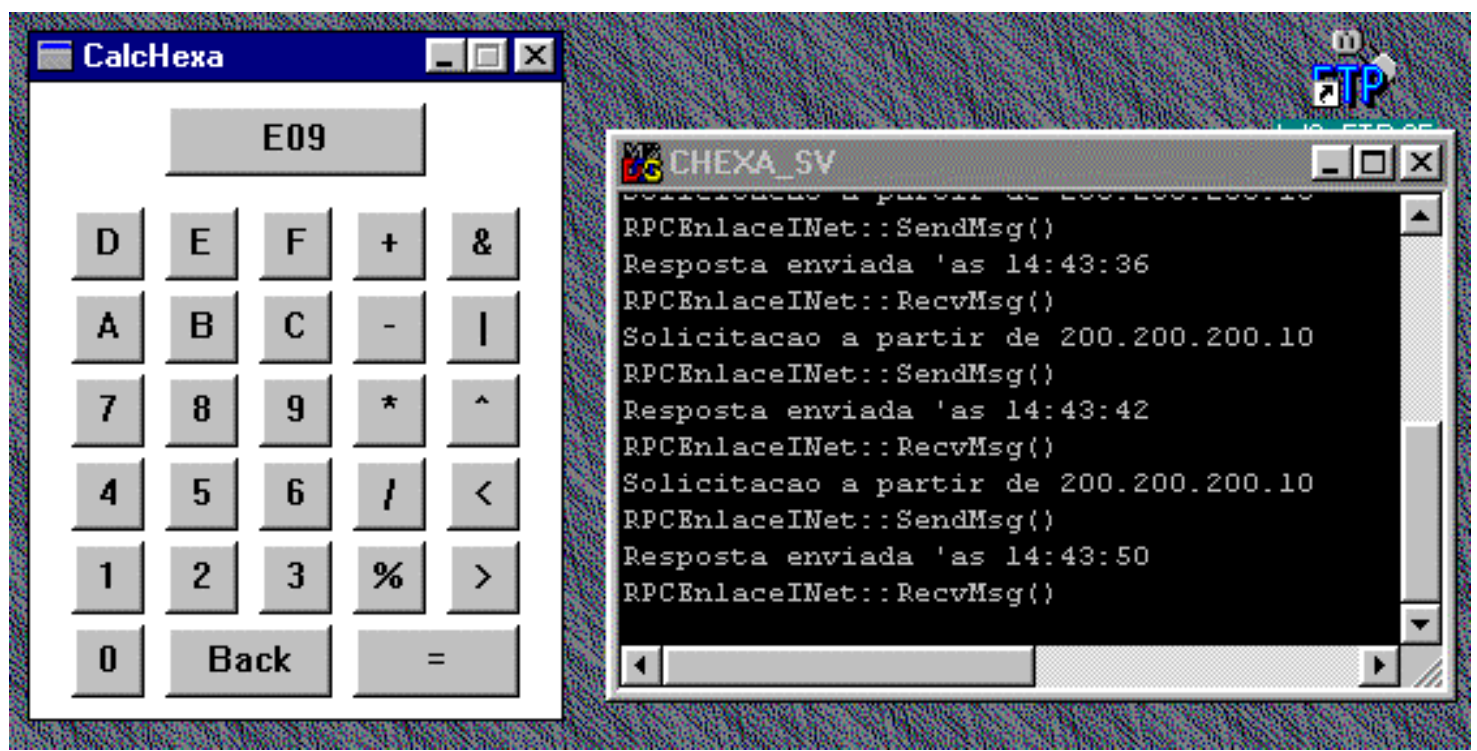

Fig. 6.1 - A Calculadora Hexadecimal

No desenvolvimento da calculadora, foi implementado no servidor apenas um procedimento para execução das operações, tendo sido feita a especificação do mesmo na IDL do sistema (fig. 6.2). Em seguida, esta foi submetida ao Gerador de Stubs a fim de produzir os stubs cliente e servidor, os quais foram encadeados com os respectivos 
módulos da aplicação. Observe que os parâmetros passados ao servidor são todos de entrada, não sendo necessário, portanto, incluir a partícula in na especificação da interface, uma vez que ela é assumida como default (seção 5.3.1). O resultado da operação solicitada é fornecido no valor de retorno da função Calcula(), sendo tarefa do mecanismo de RPCs fazê-lo chegar até o cliente.

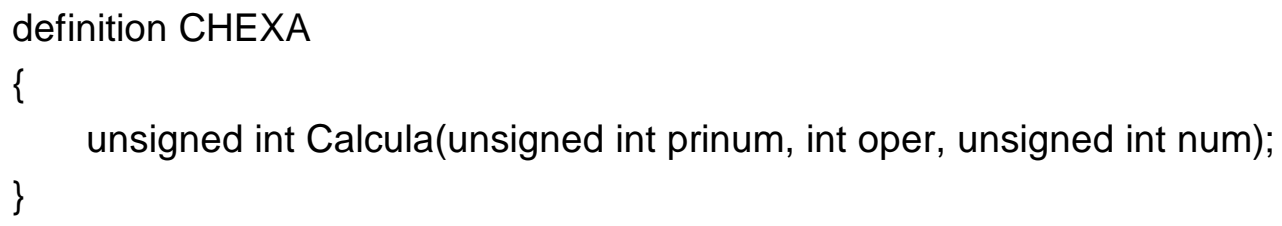

Fig. 6.2 - Especificação da interface da Calculadora

\subsection{Anallsador de Desempenho}

Em um sistema distribuído, um dos problemas com que o administrador do mesmo precisa freqüentemente se defrontar é o balanceamento de carga, ou seja, como distribuir as diferentes solicitações de serviço, que surgem a todo momento, entre as diversas máquinas, a fim de não sobrecarregar determinadas partes do sistema, deixando outras subutilizadas. Esta tarefa não é trivial, constituindo-se em objeto de pesquisa, em que se procura descobrir o algoritmo mais adequado para tal.

Contudo, é bom não esquecer que um dos passos fundamentais para se conseguir um bom balanceamento de carga é se ter uma boa fonte de informações sobre a carga do sistema em um dado momento, isto é, quanto da CPU de cada máquina está sendo utilizado, qual a taxa de utilização do disco, qual a quantidade de memória principal ocupada e assim por diante.

Esta, portanto, foi a motivação para se desenvolver um Analisador de Desempenho baseado em RPCs. No lado cliente, este permite que o usuário indique as máquinas cujo desempenho pretende avaliar e, em cada equipamento passível de análise (o servidor), fica executando um daemon, baseado em RPCs, que é responsável por atender as requisições de informações de desempenho. O cliente mantém um vetor com informações sobre como contactar cada servidor e, periodicamente, faz as chamadas remotas para obtenção de informações. O vetor mantido pelo cliente, na verdade, é uma lista de ponteiros para objetos da classe RPCEnlaceINet, criados no momento em que o usuário 
seleciona uma máquina a ser analisada. Assim, vários enlaces permanecem ativos simultaneamente. A figura 6.3 mostra um esquema da interação entre clientes e servidores.

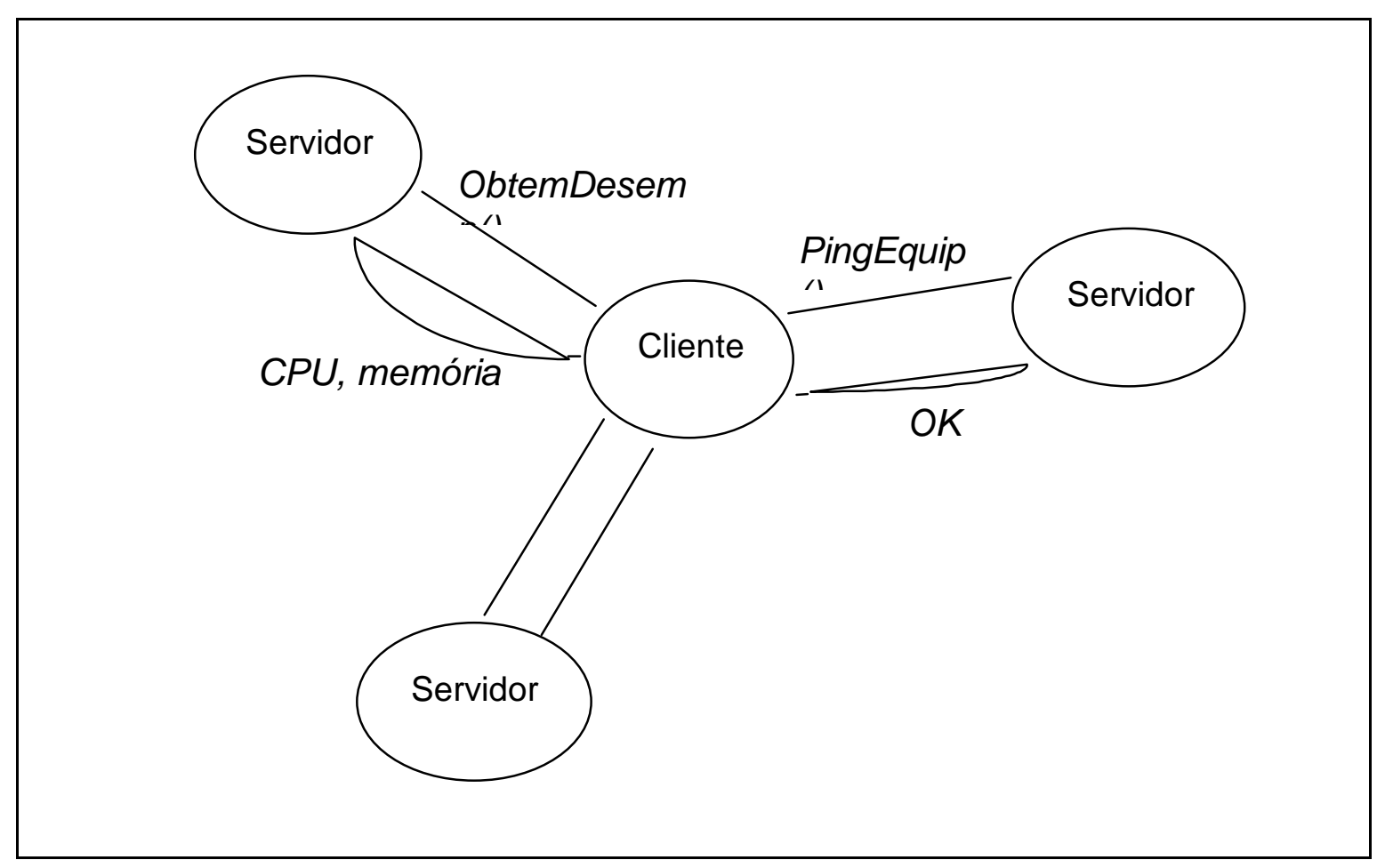

Fig 6.3 - Funcionamento do Analisador de Desempenho

Para a implementação do servidor, foram definidos dois procedimentos: ObtemDesemp() tem a função de conseguir informações referentes à utilização da CPU, ocupação do disco e da memória e, para tanto, utiliza um misto de funções da API do Windows e do MS-DOS. O outro procedimento, PingEquip(), apenas retorna uma mensagem ao cliente confirmando que a máquina selecionada para análise está funcionando adequadamente; este procedimento é chamado logo após a inicialização da RPC. Observe, na especificação dos procedimentos (fig. 6.4), a utilização da partícula out para denotar que os parâmetros de ObtemDesemp() são apenas de saída, não sendo preciso, portanto, "empacotá-los" na mensagem que chega ao servidor, o que economiza tempo de processamento e de transmissão de dados.

O Analisador de Desempenho desenvolvido não tem a pretensão de responder qual a máquina, no sistema distribuído, mais adequada para realizar uma dada tarefa. Ele apenas informa seus valores de desempenho e deixa a decisão a cargo de outra instância. 


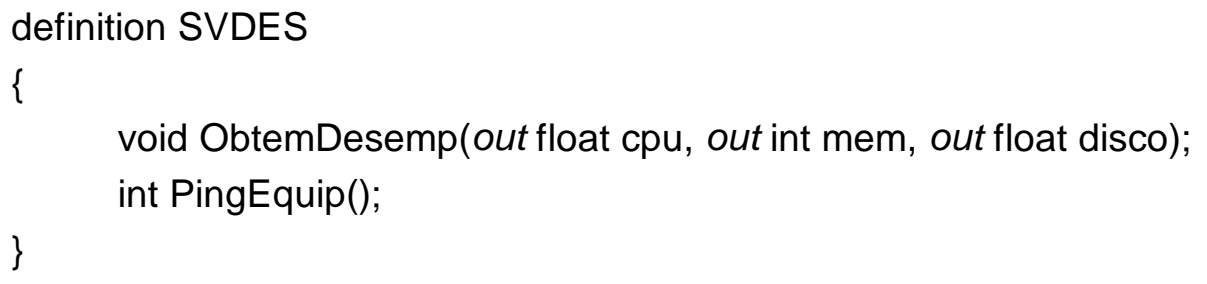

Fig. 6.4 - Especificação da interface do Analisador de Desempenho

\subsection{Servidor de Arquhos}

Um sistema de arquivos é um componente essencial em qualquer sistema operacional, seja ele centralizado ou distribuído, fornecendo aos usuários meios para criar, nomear e apagar os arquivos, assim como acrescentar e remover registros dos mesmos. Num sistema não centralizado, um sistema de arquivos distribuído é particularmente importante, pois permite que os programas tenham acesso a arquivos remotos, sem ter que copiá-los para o disco local, além de facilitar o compartilhamento dos dados, otimizando o uso dos recursos do sistema.

Assim, outro tipo de aplicação desenvolvida para validar a ferramenta ORPCw95 foi um serviço de arquivos simples, baseado no modelo cliente-servidor. $\mathrm{O}$ serviço de arquivos construído lança mão das facilidades do sistema de arquivos encontrado no ambiente Windows 95, o qual é amplamente conhecido e utilizado desde os tempos do MS-DOS. Sendo assim, o que o serviço aqui discutido faz é disponibilizar, em cada máquina em que esteja executando, uma interface para manipulação dos arquivos locais a partir de programas clientes funcionando em outros computadores (fig. 6.5).

Como módulo cliente, foi desenvolvido um programa para Windows 95 (fig. 6.6) que demonstra as potencialidades das primitivas de acesso a arquivos definidas no servidor. Vale ressaltar que a interface de procedimentos do servidor está disponível para qualquer cliente desenvolvido com a ferramenta ORPCw95; a aplicação front-end aqui apresentada é apenas uma das muitas implementações possíveis.

A interface definida para o servidor (fig. 6.7) contém primitivas básicas de manipulação de arquivos, tais como: procedimentos para criação e remoção de arquivos; leitura, escrita e anexação de dados. Há ainda primitivas para cópia de arquivos e para criação e remoção de diretórios. Os procedimentos $\operatorname{LeArq}($ ) e EscreveArq() foram projetados para ler e escrever uma seqüência de bytes (de um até muitos), portanto neles não está implícita nenhuma forma de estruturação dos dados. Qualquer interpretação nesse 
sentido fica a cargo do programa cliente, o que dá uma grande flexibilidade ao serviço de arquivos implementado, possibilitando-lhe armazenar diferentes tipos de dados, desde simples registros baseados em caracteres até representações de estruturas de dados linearizadas ou mesmo figuras. Para o serviço de arquivos, os dados são apenas um fluxo de bytes, sem nenhum significado especial.

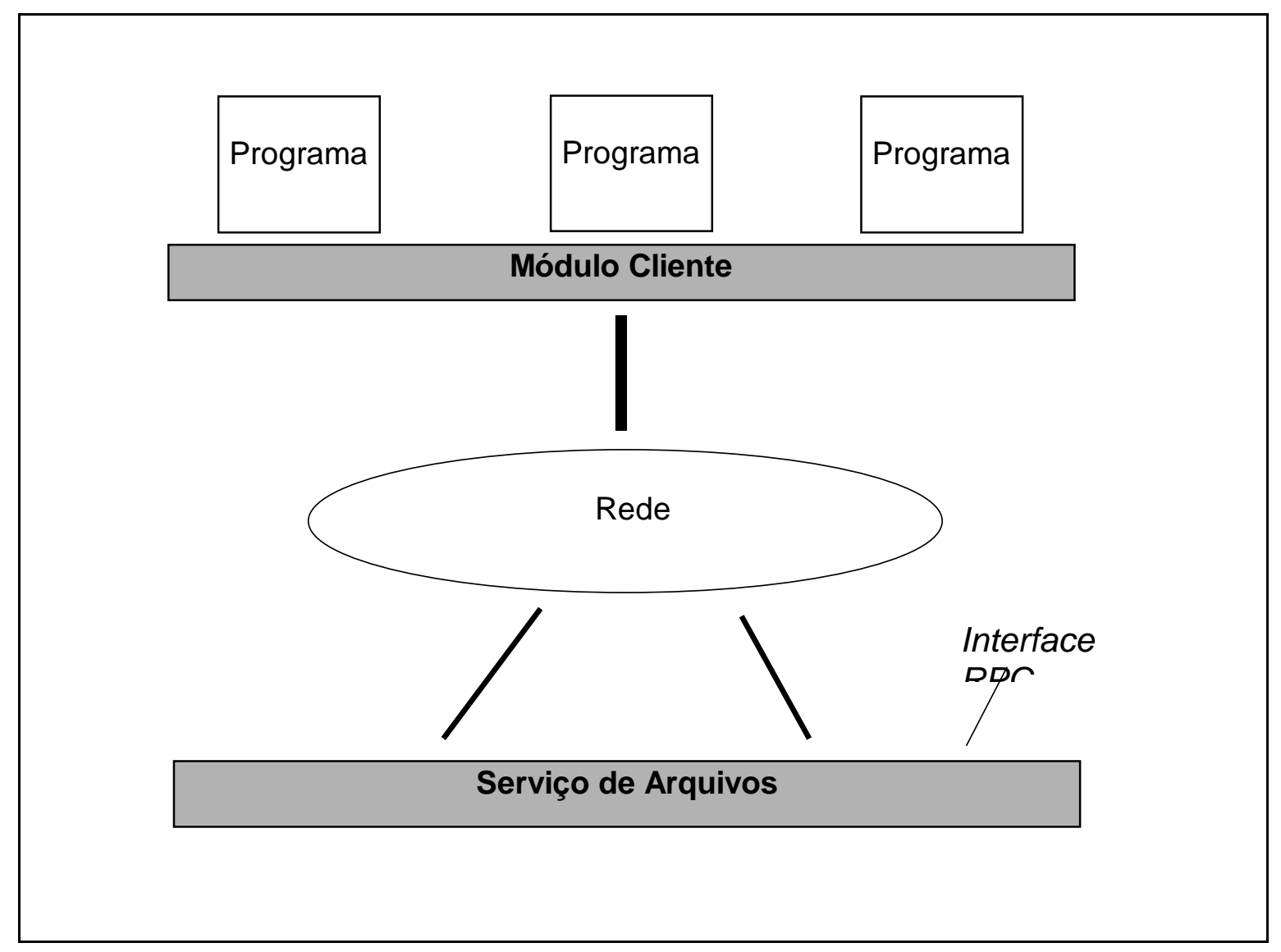

Fig. 6.5 - Arquitetura do Serviço de Arquivos

As primitivas definidas podem e devem servir de base para a construção de outras mais complexas: o procedimento CopiaArq() é um exemplo, tendo sido escrito com o uso de $\operatorname{LeArq()}$ e EscreveArq(). Observe que a interface apresentada é constituída apenas de procedimentos idempotentes, à exceção de AnexaArq(), o que é condizente com a semântica at-least-once da ferramenta de RPCs. AnexaArq() foi incluída justamente para ilustrar os perigos em que se pode incorrer caso a interface do serviço seja mal projetada e, de fato, conseguiu-se provocar situações em que o emprego daquela primitiva levou à inclusão de registros repetidos em um arquivo. 


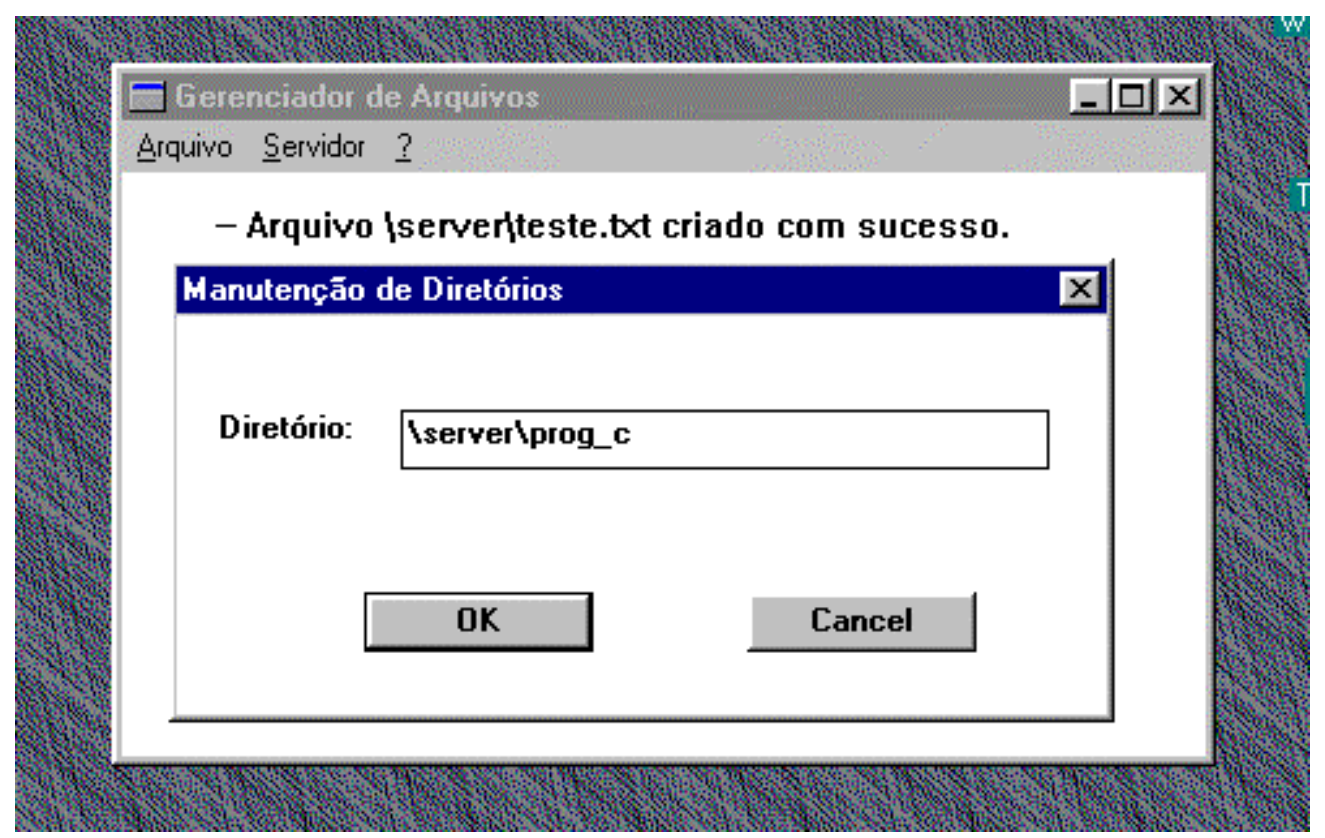

Fig. 6.6 - Exemplo de aplicação cliente para o Servidor de Arquivos

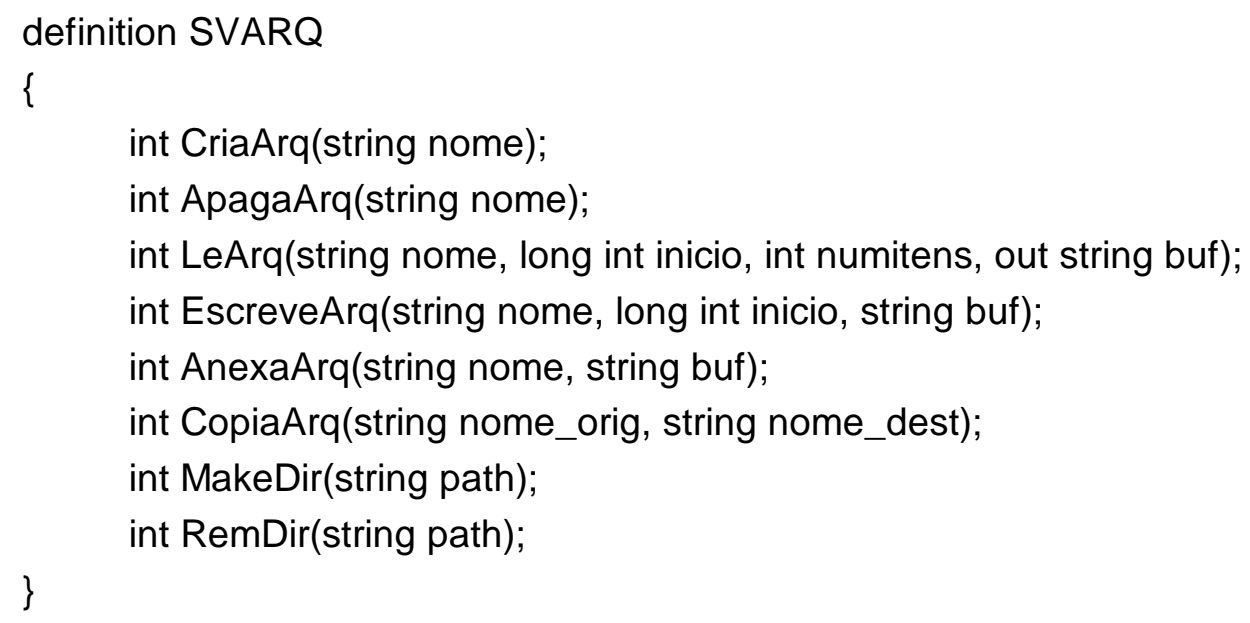

Fig. 6.7 - Especificação da interface do Servidor de Arquivos

O uso de primitivas idempotentes para a manipulação de arquivos é uma vantagem sobre o sistema de arquivos tradicional encontrado nos ambientes Windows ou UNIX, pois nestes o uso de um ponteiro de arquivo que indica a posição inicial da próxima leitura ou escrita dificulta a implementação de operações idempotentes e exige a presença de primitivas de abertura e fechamento de arquivos, o que não é necessário no servidor 
apresentado. O servidor de arquivos definido, portanto, é do tipo stateless, isto é, não guarda nenhuma informação de estado referente aos clientes [Cou94].

\subsection{Degenowimento de Apllcaçōes com ORPCw95}

Neste ponto, já é possível esboçar uma metodologia básica a ser seguida para o desenvolvimento de aplicações utilizando-se a ferramenta ORPCw95. No Capítulo 4, foram fornecidas orientações gerais para a construção de aplicações distribuídas, qualquer que seja o ambiente ou ferramenta utilizados e estas são válidas também para o desenvolvimento de aplicações na plataforma Windows 95, devendo-se tê-las sempre em mente.

Como passo inicial, vários autores recomendam que se deva (1) construir uma aplicação centralizada convencional para resolver o problema em questão, pois assim é possível depurar todos os problemas "locais" da aplicação, antes de se preocupar com as dificuldades que possam surgir com a sua distribuição [Blo95][Com93]. É claro que tal recomendação, na prática, deve ser seguida apenas para sistemas realmente complexos. $\mathrm{O}$ passo seguinte é (2) visualizar a aplicação construída (ou projetada) a fim de determinar qual parte da mesma deverá permanecer local e qual deverá ser executada remotamente, ou seja, subdividi-la em partes cliente e servidor, o que nem sempre é uma tarefa trivial [Blo95][Inm93][Koe95]. Os passos comentados são recomendações de ordem geral e não necessariamente são exigidos pela ferramenta ORPCw95.

Tendo-se definido os procedimentos que vão ser executados no servidor, a etapa seguinte compreende (3) a especificação da interface dos procedimentos remotos na IDL do sistema, incluindo-se aí quaisquer definições globais, estruturas ou uniões utilizadas no programa. Geralmente, não há grandes dificuldades nesta fase, principalmente quando se utiliza no desenvolvimento do sistema a linguagem "C". Feito isto, deve-se (4) submeter a especificação $(* . x)$ ao Gerador de Stubs do sistema (rpc95), o qual irá produzir um arquivo de cabeçalho com definições globais $(* . h)$, bem como os stubs cliente (*_cl.cpp) e servidor (*_sv.cpp).

A etapa seguinte consiste em (5) compilar e ligar os programas cliente e servidor com os respectivos stubs e a Biblioteca RPC, produzindo-se, como resultado, os módulos cliente e servidor. Para esta etapa, geralmente é preciso criar algum tipo de "arquivo de projeto" no ambiente de desenvolvimento que se esteja utilizando. Nos exemplos apresentados, foi usado o ambiente Borland $C++4.5$. Não se deve esquecer que, no módulo cliente, o programa principal é a aplicação Windows e, no servidor, é o stub que desempenha esta função. 
Com os módulos já prontos, é preciso apenas (6) iniciar a execução do servidor em uma máquina remota e aguardar as solicitações vindas dos clientes. Antes de se dar início ao servidor, é preciso certificar-se de que já existe um Binder ( $\left.p m a p \_s\right)$ executando na máquina.

Observa-se, portanto, que o processo de desenvolvimento de aplicações com o uso da ferramenta ORPCw95 é simples e deixa totalmente transparente ao programador os detalhes de distribuição das aplicações. A seguir, será mostrado que tipo de alterações devem ser feitas nos programas Windows 95 para criar suporte a RPCs com o uso desta ferramenta.

\subsubsection{Programa Mínimo no Windows 95}

Desde o início deste projeto, uma preocupação constante é garantir que a introdução das RPCs nas aplicações tenha o menor impacto possível na maneira tradicional de se desenvolver aplicações para o ambiente Windows, de modo que seja possível alcançar uma transparência não só em relação à execução da RPC, mas durante o próprio processo de construção das aplicações distribuídas, o que, com certeza, só contribui para aumentar a produtividade dos programadores que utilizem a ferramenta.

Criar o módulo servidor é tarefa simples, pois o programa servidor é igual a um arquivo convencional escrito em linguagem $\mathrm{C}$, contendo os procedimentos ou funções que, numa aplicação centralizada, seriam ligados com o programa principal. Assim, o programador precisa apenas agrupar os procedimentos servidores em um arquivo único, não sendo necessária nenhuma modificação no código dos mesmos por causa da introdução das RPCs. O programa principal que vai invocá-los é justamente o stub servidor.

Quanto ao programa cliente, são necessárias algumas pequenas modificações para que o mesmo possa lançar mão das chamadas remotas:

a) Deve-se declarar, na área de variáveis globais do programa, um ponteiro para um objeto do tipo RPCEnlaceINet, o qual funciona como um handle da RPC [Sun90], armazenando as informações relevantes para o enlace estabelecido entre o cliente e o servidor:

$\cdots$

// ORPCw95

CLIENTE * ${ }^{*}$ = new CLIENTE;

. .

O identificador “CLIENTE” é um typedef [Sch92] para RPCEnlaceINet. 
b) No laço de tratamento de mensagens do programa Windows, deve-se incluir, na mensagem WM_CREATE, o método de inicialização da RPC, definido na classe RPCCall:

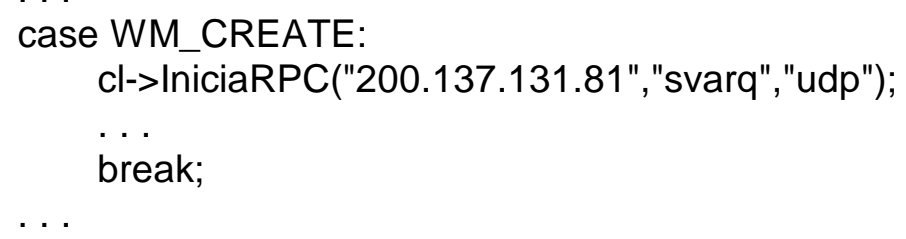

Neste método, é informado o endereço IP da máquina onde se encontra o programa servidor, o nome da interface do serviço e o protocolo que se deseja utilizar. O nome da interface deve estar previamente registrado no Binder da máquina que contém o processo servidor.

c) Para cada procedimento remoto chamado no programa, o handle da RPC deve ser sempre o último elemento da sua lista de parâmetros. Por exemplo:

Como já foi comentado, o procedimento que está sendo invocado não é o procedimento servidor de fato, mas sim o stub cliente, que tem a tarefa de contactar o procedimento servidor real; o handle que lhe é passado como parâmetro contém as informações relativas à RPC em curso.

d) Ao finalizar o programa, é necessário também encerrar o enlace estabelecido entre cliente e servidor, liberando os buffers alocados, sockets, portas, dentre outros recursos. Para tanto, deve-se incluir, na mensagem WM_DESTROY do laço de mensagens do programa, o seguinte trecho de código:

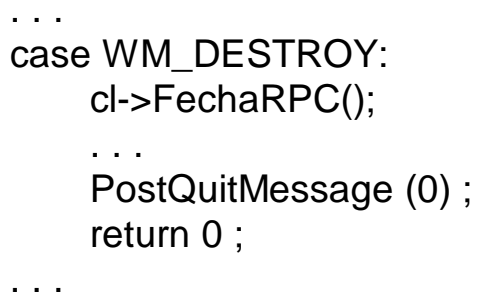

Como é possível constatar, é bem simples introduzir RPCs nos programas Windows com o uso da ferramenta ORPCw95: basta, apenas, invocar os métodos de 
inicialização e término da RPC nos locais apropriados e incluir o handle da RPC na lista de parâmetros dos procedimentos chamados.

É importante ressaltar que tudo que o programador precisa conhecer a respeito da ferramenta resume-se aos métodos e passos descritos acima. Toda a complexidade inerente à comunicação entre os módulos da aplicação fica completamente escondida dentro do código dos stubs e da Biblioteca RPC. Aplicações distribuídas escritas com o uso da API Windows Sockets, simplesmente, são notavelmente mais complexas de codificar e compreender e a "mistura" entre o código propriamente dito da aplicação e o código relacionado apenas com a comunicação fica evidente [Blo92][Bon96].

\subsection{Códlgo dos Ptocedimentos Stubs}

A fim de se conhecer um pouco mais sobre as características da interação entre clientes e servidores, sob a ferramenta ORPCw95, pretende-se agora analisar o código do arquivo de cabeçalho e dos procedimentos stubs produzidos pelo Gerador. Será utilizado como exemplo um trecho dos procedimentos gerados para o Servidor de Arquivos.

$\mathrm{O}$ arquivo de cabeçalho (fig. 6.8) contém definições internas à ferramenta que serão úteis tanto ao stub cliente quanto ao servidor, tais como: macros para os números dos procedimentos remotos e protótipos destes no servidor. Além disso, quaisquer definições fornecidas pelo programador como variáveis globais, estruturas ou uniões também vão estar contidas neste arquivo. Note-se que, ao final da especificação de cada procedimento, existe um ponteiro para um objeto da classe RPCEnlaceINet, representado pelo mnemônico (CLIENTE *), o qual é usado no código dos stubs para acesso aos métodos da Biblioteca RPC.

Quanto ao stub cliente, seu código constitui-se de uma série de pequenas funções (fig. 6.9), cada uma representando, no lado cliente da aplicação, um procedimento servidor real. Cada função segue os seguintes passos:

- Contacta o Binder da máquina servidora a fim de descobrir se o procedimento solicitado está disponível (BindCli);

- Monta o cabeçalho da mensagem RPC (MontaHeaderMsg);

- Para cada parâmetro de entrada ou entrada/saída, coloca-o na mensagem de ida (MontaMsg);

- Realiza a chamada remota e aguarda os resultados ( Call);

- Retira o valor de retorno (se houver) da mensagem de volta (DesmontaMsg);

- Retira os parâmetros de saída ou entrada/saída da mensagem (DesmontaMsg); 
- Limpa a mensagem (LimpaMsg);

- Finaliza, devolvendo o valor de retorno à aplicação cliente (return ret).

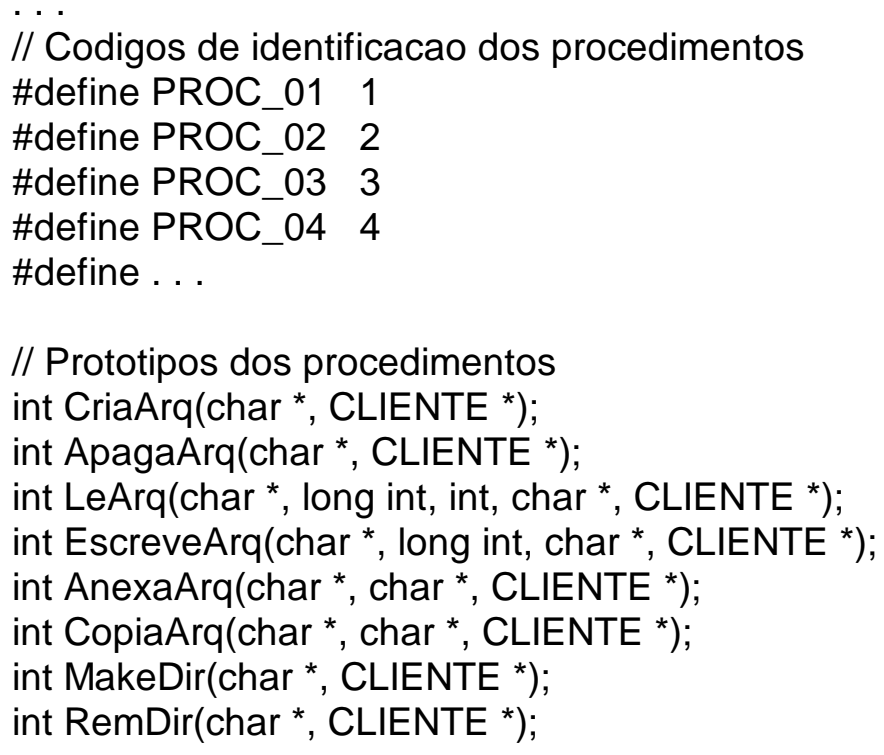

Fig. 6.8 - Arquivo de cabeçalho para o Servidor de Arquivos

Cada um dos métodos citados chama diversos outros para realizar a tarefa a que se propõe, os quais, por sua vez, podem invocar outros métodos e assim por diante. Aqui, não se pretende descer a esse nível de detalhes, porém vale a pena destacar a independência do código do stub cliente em relação ao protocolo de comunicação utilizado para a troca das mensagens, bem como em relação à estrutura interna das mensagens RPC e à forma de implementação do Binder. Portanto, como foi dito na seção 5.5.4, torna-se fácil fazer manutenções na ferramenta, além disso ser transparente ao usuário da mesma.

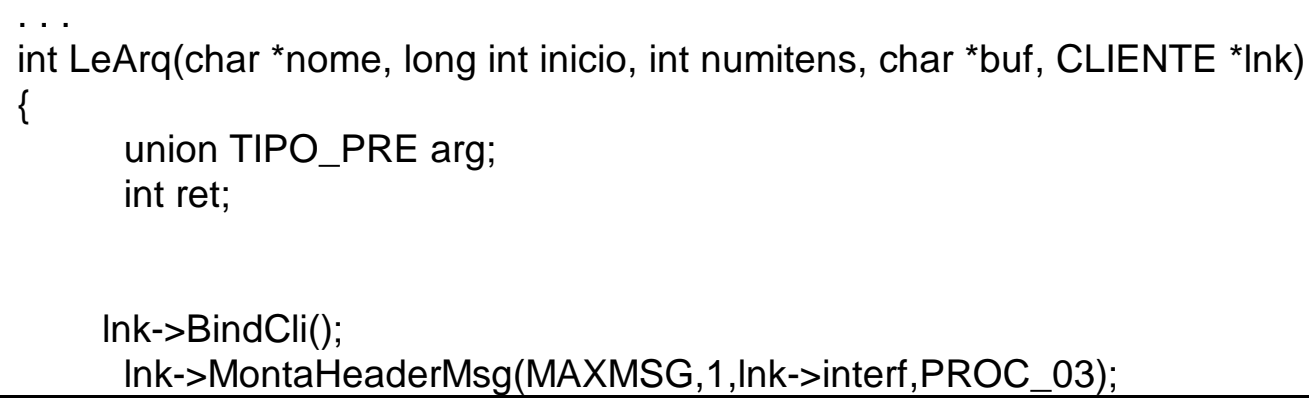




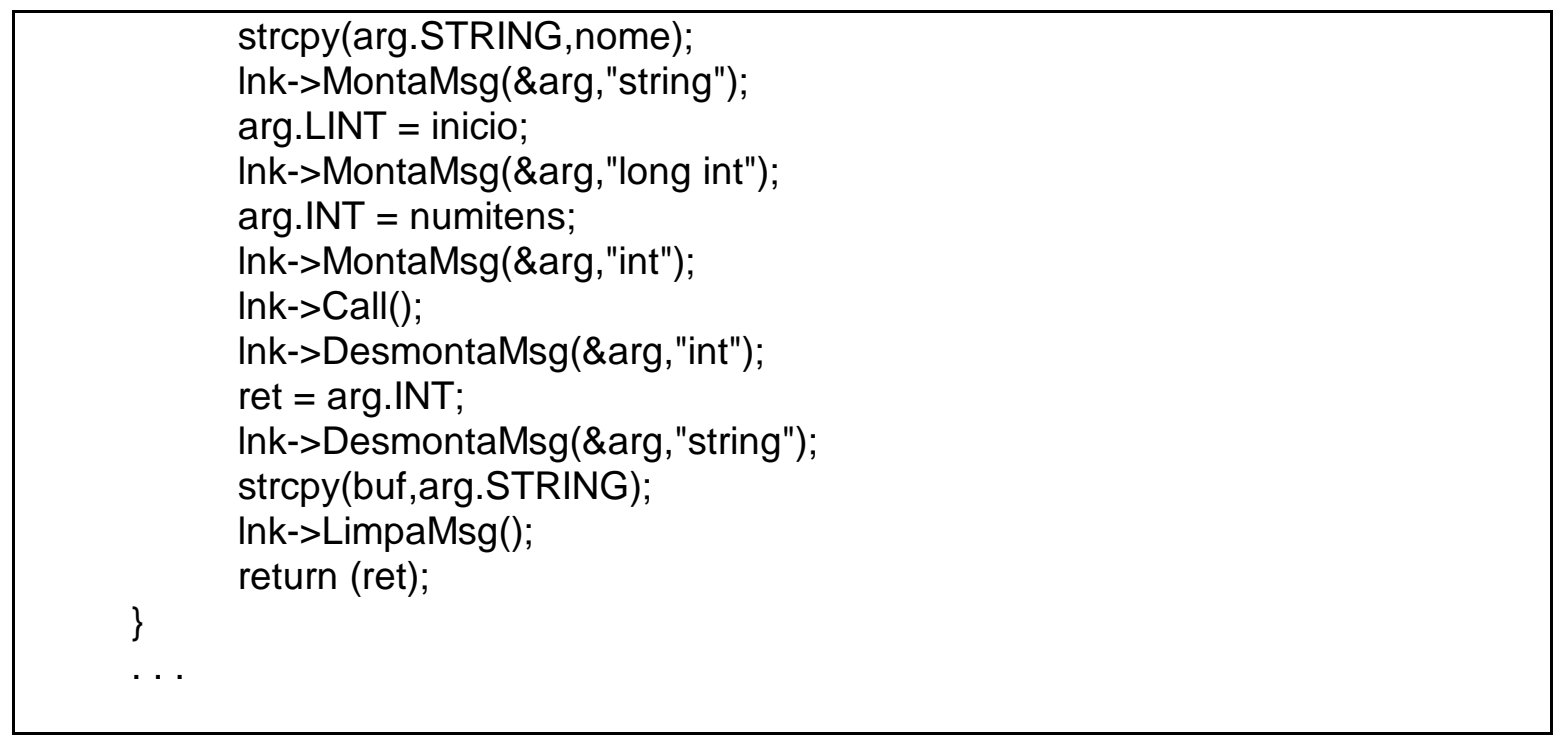

Fig. 6.9 - Trecho do stub cliente para o Servidor de Arquivos

O stub servidor, por sua vez, possui um laço principal em que são recebidas as mensagens de solicitação de serviços e, para cada procedimento servidor real, existe um procedimento stub correspondente. Os passos tomados são os seguintes:

- Verifica os parâmetros passados na linha de comando;

- Inicializa a RPC (IniciaRPC);

- Registra a interface do serviço no Binder (BindSrv);

- Laço infinito:

- Recebe a mensagem de solicitação de serviço (RecvMsg);

- Retira o cabeçalho da mensagem RPC (DesmontaHeaderMsg);

- Executa o procedimento solicitado na mensagem;

- Envia a mensagem com os resultados ao cliente (SendMsg);

- Limpa a mensagem (LimpaMsg);

- Se o usuário pressionar $\langle\mathrm{ESC}\rangle$

- Finaliza o serviço sendo oferecido (UnBindSrv);

- Interrompe o laço.

Portanto, cada procedimento servidor real (fig. 6.10) possui como porta de entrada um procedimento stub, chamado a partir do laço principal do programa, que recebe a mensagem vinda do cliente e trata dos detalhes de comunicação, segundo o esquema a seguir:

- Retira os parâmetros contidos na mensagem que chegou e os atribui a variáveis locais (DesmontaMsg);

- Chama o procedimento servidor real $($ ret $=\ldots)$; 
- Limpa a mensagem (LimpaMsg);

- Coloca os parâmetros de saída e entrada/saída na mensagem de volta (MontaMsg);

- Retorna ao programa principal.

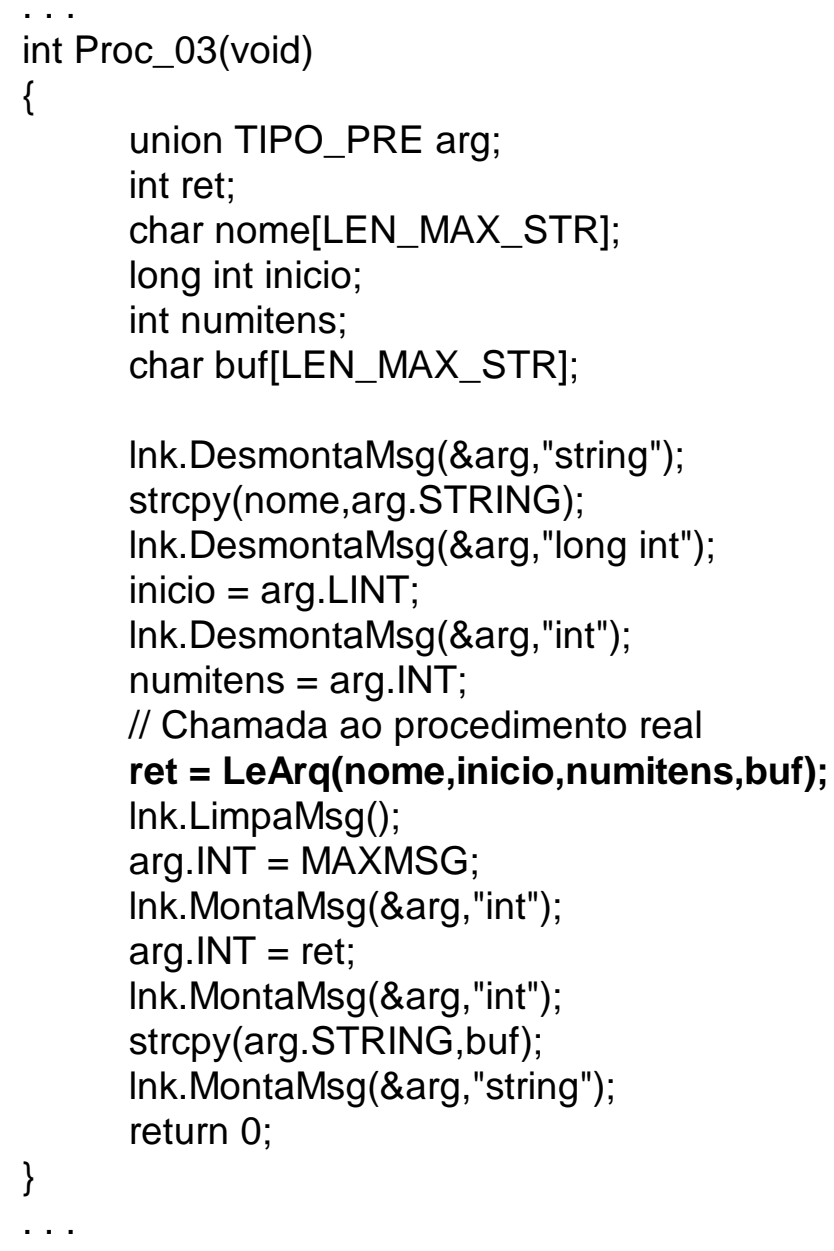

Fig. 6.10 - Trecho do stub servidor para o Servidor de Arquivos

A exemplo do stub cliente, o código do $s t u b$ servidor também é independente do protocolo de comunicação utilizado e da forma de implementação do Binder. Observe que o procedimento servidor real é chamado com exatamente os mesmos parâmetros utilizados na aplicação cliente, não sendo preciso agrupá-los em uma estrutura, como é o caso do Sun RPC [Cou94][Sun90], o que aumenta a transparência de uso da ferramenta.

A interface do programa servidor, assim como a do Binder, é baseada em caracteres, pois o mesmo funciona como uma espécie de daemon na máquina em que está 
executando, não sendo necessário ter uma interface Windows, o que poderia até mesmo comprometer seu desempenho, pois é sabido que interfaces gráficas introduzem uma certa sobrecarga em qualquer sistema. Entretanto, o código do módulo servidor é todo escrito em 32 bits, tanto os procedimentos stubs quanto os reais.

Para concluir, convém reforçar que todo o código dos procedimentos stubs é produzido unicamente pelo Gerador de Stubs da ferramenta ORPCw95, a partir da especificação dos procedimentos remotos feita na IDL do sistema (fig. 6.7), sem nenhuma interferência do programador, que não precisa conhecer a implementação dos procedimentos para desenvolver as aplicações distribuídas. Desse modo, atinge-se a almejada transparência no desenvolvimento de aplicações, que é o objetivo final de qualquer sistema de RPCs, permitindo-se que os programadores concentrem-se no programa que têm que desenvolver e esqueçam os detalhes relativos a sua distribuição.

\subsection{Avallaçāo de Desempenho da Ferramenta}

Para concluir a etapa de testes e validação da ferramenta, apresenta-se um comparativo do desempenho entre uma aplicação distribuída que utiliza apenas os Windows Sockets para comunicação e outra que faz uso de RPCs via ORPCw95. A escolha dos Windows Sockets para a comparação deve-se ao fato de que esta API é amplamente utilizada no desenvolvimento de aplicações distribuídas, no ambiente Windows, tendo se tornado praticamente um padrão. A própria biblioteca ORPCw95 foi escrita com a utilização das funções da API Winsock.

\subsubsection{Ambiente de Testes}

O ambiente de testes utilizado para a comparação constitui-se de microcomputadores Pentium $100 \mathrm{MHz}$, da IBM, com 16 Mbytes de memória principal, interligados por uma rede local convencional do tipo Ethernet, a $10 \mathrm{Mbps}$, tendo cabos de par trançado como meio físico de transmissão de dados. Os computadores executavam Windows 95 e usavam como protocolo de comunicação o pacote TCP/IP da Microsoft, na versão de 32 bits.

\section{7 .2 Obtençào dos Dados}

Para medir o desempenho, inicialmente foi elaborada a seguinte aplicação: o programa cliente, ao ser iniciado, envia uma mensagem contendo 100 bytes quaisquer ao servidor, o qual responde com um byte informando da chegada da mensagem. O cliente 
mostra, então, na tela os tempos de transmissão e recepção da mensagem, com precisão de milissegundos. Foram produzidas duas versões do programa: uma utilizando a API Windows Sockets (WSOCK32.DLL) e outra baseada na API ORPCw95.

A aplicação escolhida, como se pode ver, é a mais simples possível, pois o que se pretende aferir não é o desempenho de máquinas, mas sim a sobrecarga na comunicação imposta pelo uso de uma biblioteca de RPCs, orientada a objetos, bem como possíveis atrasos ocasionados pelas mudanças de contexto entre os programas cliente e servidor e os procedimentos stubs.

A aplicação Windows Sockets construída faz um polling [Bon96] para a obtenção dos dados devolvidos pelo servidor, isto é, após enviar a mensagem de solicitação de serviços o cliente verifica, de tempos em tempos, se a resposta já chegou (o intervalo utilizado, neste caso, foi de $10 \mathrm{~ms}$ ). Outra possibilidade para o desenvolvimento da aplicação seria o programa cliente solicitar ao Windows que o "avisasse" da chegada de uma mensagem vinda da rede. Em ambos os casos, o tratamento dado à recepção das mensagens é assíncrono, evitando que o programa cliente fique "paralisado" enquanto aguarda o atendimento da solicitação pelo servidor. Essas formas de implementação são bastante comuns em aplicações distribuídas escritas para o ambiente Windows [Bon96].

Para a obtenção dos dados da aplicação ORPCw95, utilizou-se um timeout de $10 \mathrm{~ms}$ para as chamadas remotas (seção 5.4.5), que é o mesmo intervalo usado no caso dos Windows Sockets. A Biblioteca RPC trata o envio e recepção das mensagens de modo síncrono, ou seja, após enviar a mensagem o programa cliente fica aguardando seu resultado, só retornando o controle ao Windows após a chegada do mesmo ou, então, ao expirar o tempo da RPC.

Para a coleta dos dados relativos ao desempenho, foram feitas dez partidas com dez transmissões de mensagens em cada uma delas, tanto para as RPCs quanto para os Windows Sockets.

\subsubsection{Análise dos Resultados}

Analisando-se os dados obtidos, foi possível constatar que o desempenho das aplicações em ambos os casos foi virtualmente o mesmo, com uma pequena vantagem das RPCs em algumas medições. Imaginou-se, então, que tal fato ocorria porque, no caso da aplicação Windows Sockets, a mensagem (em nível de sistema operacional) que avisa o programa da chegada dos dados, passa pelo laço de tratamento de mensagens do Windows, o que certamente causa algum atraso, devido ao fato da mesma precisar entrar 
numa fila do sistema operacional [Mic95d][Pie93]. No caso da Biblioteca RPC, a chegada dos dados é tratada imediatamente, sem gerar uma mensagem para o Windows.

A fim de se poder ter uma outra visão dos dados, decidiu-se desenvolver a aplicação Windows Sockets de modo síncrono, para eliminar o atraso mencionado acima. Além disso, passou-se a enviar 1000 bytes de dados na mensagem de ida e também 1000 bytes na mensagem de retorno, para verificar se a quantidade de dados transmitidos influiria nos resultados obtidos.

Novamente, os resultados encontrados foram praticamente os mesmos, sem aquela ligeira vantagem notada anteriormente em favor das RPCs. Em ambos os casos analisados, um dos fatores que dificultou o trabalho foi o fato do ambiente de programação utilizado (o Borland $C++4.5$ ) não possuir funções que forneçam o tempo com precisão de microssegundos. Mesmo na segunda situação, em que foram transmitidos 2000 bytes de dados em cada solicitação, o tempo de resposta era muito rápido, não sendo possível medi-lo com exatidão na ordem de grandeza de $10^{-3} \mathrm{~s}$.

A partir dos resultados acima, pode-se concluir que a ferramenta de RPCs apresentada não produz aplicações distribuídas com desempenho inferior ao obtido com aplicações feitas da maneira convencional, isto é, aquelas em que o próprio programador tem que escrever toda a parte de comunicação e pode otimizá-la à vontade. As diferenças de desempenho que possam existir entre as aplicações ORPCw95 e as baseadas em Windows Sockets estão abaixo da casa dos milissegundos, sendo, portanto, totalmente imperceptíveis para o usuário final.

Além disso, o mecanismo ORPCw95 apresenta duas vantagens consideráveis: em primeiro lugar, destaca-se o alto nível de produtividade alcançado pelos programadores, ao usar a ferramenta e, em segundo lugar, a utilização do gerador de stubs fornecido garante que, pelo menos sob o ponto de vista das rotinas de comunicação, a aplicação desenvolvida está sempre correta, o que libera os programadores para tarefas mais nobres, permitindo-lhes concentrar-se nas características da aplicação em questão.

\subsection{Concluscio}

Neste Capítulo, apresentaram-se algumas aplicações distribuídas desenvolvidas com o suporte da ferramenta ORPCw95, destacando-se os aspectos principais de sua implementação. Foi discutida também uma metodologia para o desenvolvimento de aplicações com o uso da ferramenta e apresentado um esboço de programa mínimo no Windows 95 com suporte a RPCs. Foram abordados também os detalhes de implementação do código dos procedimentos stubs. Finalmente, apresentou-se uma 
comparação do desempenho de uma aplicação baseada em Windows Sockets e outra baseada na ferramenta desenvolvida. 


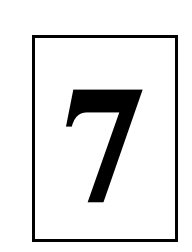

\section{Conclusão}

Este trabalho apresentou uma ferramenta de suporte a RPCs para o ambiente Windows 95, com o objetivo de facilitar o desenvolvimento de aplicações distribuídas nesta plataforma.

Inicialmente, fez-se um estudo sobre os sistemas distribuídos, destacando-se suas características relevantes, dificuldades de implementação e mecanismos de comunicação utilizados. Em seguida, foram apresentadas as chamadas a procedimentos remotos (RPCs), analisando-se os detalhes de seu funcionamento, o gerenciamento de falhas e as formas de localização dos serviços no sistema distribuído. Foi mostrado, também, um panorama das principais implementações de ferramentas de suporte a RPCs, atualmente, bem como discutidas estratégias para o desenvolvimento de aplicações distribuídas.

A ferramenta desenvolvida, denominada $O R P C w 95$, é composta por um gerador automático de stubs, uma biblioteca RPC e um servidor de binding implementado em cada máquina. Como principais características, apresenta o uso da semântica at-least-once nas chamadas remotas; o emprego da metodologia de orientação a objetos no desenvolvimento da Biblioteca RPC; a escolha da família de protocolos TCP/IP para a comunicação; e o desenvolvimento de todo o código em 32 bits.

A existência de uma ferramenta desse tipo para a plataforma Windows 95 facilita sobremaneira o desenvolvimento de aplicações distribuídas nesse ambiente, pois permite que projetistas e programadores concentrem-se na tarefa que lhes foi confiada, deixando 
os detalhes (e problemas) referentes à comunicação e à passagem de mensagens a cargo do subsistema de RPCs.

Como destaque das contribuições mais importantes do trabalho, apresentam-se a simplicidade e transparência na construção das aplicações distribuídas, o que, aliás, foi uma preocupação constante desde o início do projeto. Como consequiência, as alterações que precisam ser feitas em um programa Windows tradicional, para criar suporte a RPCs, são mínimas, em nada interferindo na lógica de programação normalmente adotada. Os passos necessários para criar os stubs também são bastante simples, não representando um grande esforço adicional. Dessa forma, programadores já experientes no ambiente Windows tornam-se imediatamente produtivos com a utilização da ferramenta.

Sob o ponto de vista do usuário final das aplicações desenvolvidas com o uso da ferramenta, o emprego das RPCs é totalmente transparente, não se evidenciando nenhuma modificação no seu modo de interação com os programas. E, no quesito desempenho, o mecanismo de RPCs desenvolvido mostrou-se mais que satisfatório: em testes realizados, obteve-se um tempo de resposta equivalente ao obtido com aplicações distribuídas, construídas apenas com o uso da API Windows Sockets. Assim, sob o presente mecanismo, o emprego de RPCs não compromete o bom desempenho que se espera das aplicações.

A simplicidade no uso da ferramenta e a pequena sobrecarga que esta impõe às aplicações não significam, entretanto, que a mesma seja desprovida de recursos ou avessa a melhoramentos: todas as facilidades necessárias à implementação de aplicações distribuídas reais estão presentes e a inclusão de novas características é facilitada pela orientação a objetos adotada.

Em se tratando de aplicações, foram desenvolvidas algumas delas a fim de validar a ferramenta construída, tendo sido feita também uma revisão bibliográfica sobre a construção de aplicações distribuídas baseadas em RPCs, relatando-se alguns caminhos e abordagens a serem adotados no processo de desenvolvimento.

Como exemplo de melhoramentos ou trabalhos futuros que se podem desenvolver a partir da ferramenta ORPCw95, têm-se:

- Expandir a linguagem de especificação dos procedimentos remotos para dar suporte a vetores multidimensionais e estruturas de dados encadeadas por ponteiros, o que conferiria maior flexibilidade às aplicações;

- Introduzir outras semânticas para as RPCs, criando novas possibilidades de interação entre os módulos da aplicação. As alterações para permitir isto devem ser feitas na classe RPCEnlaceCliente; 
- Permitir a utilização de outros protocolos para comunicação, como, por exemplo, o protocolo TCP, os da família IPX/SPX, NetBEUI ou até mesmo protocolos especialmente desenvolvidos para o uso com RPCs. Para tanto, basta alterar a Biblioteca RPC no nível da classe RPCEnlaceINet;

- Possibilitar o uso de interconexões assíncronas na realização das RPCs, o que é viabilizado a partir do momento em que se passa a utilizar o protocolo TCP. Seria preciso, além disso, alterar alguns métodos da classe RPCEnlaceCliente;

- Experimentar o uso de outras arquiteturas para o serviço de binding, como um Binder central ou diversos binders replicados para aumentar a confiabilidade do sistema;

- Acrescentar procedimentos para conversão de dados entre sistemas heterogêneos, possibilitando a execução de RPCs em máquinas com arquitetura diversa da máquina cliente (por exemplo, programas Windows invocando RPCs em máquinas Sun). Para tanto, deve-se acrescentar à Biblioteca RPC uma classe com métodos destinados à conversão de dados, possivelmente acima da classe RPCCall, hierarquicamente falando;

- Viabilizar o uso de múltiplas threads no código dos procedimentos stubs, no servidor, a fim de permitir a execução de RPCs em paralelo;

- Finalmente, introduzir formas de autenticação de usuários, aumentando o grau de segurança das aplicações.

Como é possível constatar, são várias as direções em que se pode expandir e melhorar o trabalho apresentado, o que, por sinal, é um objetivo que também se tinha em mente ao iniciá-lo. Além disso, pelo fato de se ter utilizado a orientação a objetos para a construção da Biblioteca RPC, onde se dá a maior parte das alterações, o esforço para introduzi-las é sensivelmente diminuído, uma vez que pouco se tem que modificar do que já está pronto.

O presente trabalho, portanto, conseguiu atingir seus objetivos, fornecendo uma ferramenta poderosa e de fácil utilização para o desenvolvimento de aplicações distribuídas no ambiente Windows 95, além de delinear algumas diretrizes a serem seguidas durante o desenvolvimento de aplicações desse tipo. 


\section{Referências Bibliográficas}

[Aho86] Aho, A. V. et. al. Compilers: Principles, Techniques and Tools. AddisonWesley, 1986.

[Blo92] Bloomer, J. Power Programming with RPC. O’Reilly \& Associates, 1992.

[Blo95] Bloomer, J. Distributed Computing and the OSF/DCE. Dr. Dobb's Journal, vol. $20, \mathrm{n}^{\mathrm{o}} 227$. Fevereiro, 1995.

[Bon96] Bonner, P. Network Programming with Windows Sockets. Prentice-Hall, 1996.

[Boo94] Booch, G. Object-Oriented Analysis and Design with Applications. $2^{\mathrm{a}}$ ed. Benjamin/Cummings, 1994.

[Coa92] Coad, P. \& Yourdon, E. Análise Baseada em Objetos. $2^{\mathrm{a}}$ ed. Yourdon Press, 1992.

[Com91] Comer, D. Internetworking with TCP/IP: Principles, Protocols and Architecture, vol. 1. Prentice-Hall, 1991.

[Com93] Comer, D. \& Stevens, D. Internetworking with TCP/IP: Client-Server Programming and Applications, vol. 3. Prentice-Hall, 1993.

[Cou94] Coulouris, G. F. et al. Distributed Systems: Concepts and Design. $2^{\mathrm{a}}$ ed. Addison-Wesley, 1994.

[Hun92] Hunt, C. TCP/IP Network Administration. O’Reilly \& Associates, 1992.

[Inm93] Inmon, W. H. Developing Client/Server Applications. John Wiley, 1993.

[Koe95] Koelmel, R. L. Implementing Application Solutions in a Client/Server Environment. John Wiley, 1995.

[Kor93] Korzeniowski, P. Make Way for Data: Middleware. Byte, vol. 18, $\mathrm{n}^{\mathrm{o}} 7$, 
pp. 113-5. Junho, 1993.

[Man89] Manson, C. \& Thurber, K. Remote Control: RPCs. Byte, vol. 14, $\mathrm{n}^{\mathrm{o}} 7$, pp. 235-40. Julho, 1989.

[Mic95a] Microsoft Corp. Future Microsoft Products. Página HTML, http://www. microsoft.com/BackOffice/reading/bst11120.htm. Julho, 1995.

[Mic95b] Microsoft Corp. Microsoft's Perspective on DCE. Página HTML, http://www. microsoft.com/BackOffice/reading/bst10000.htm. Julho, 1995.

[Mic95c] Microsoft Corp. Remote Procedure Call (RPC). Página HTML, http://www. microsoft.com/BackOffice/READING/bst17010.htm. Julho, 1995.

[Mic95d] _. Readings on Microsoft Wndows and WOSA. Microsoft Press, 1995.

[Mil94] Millikin, M. D. DCE: Building the Distributed Future. Byte, vol. 19, n ${ }^{\circ}$, pp. 125-34. Junho, 1994.

[Mon94] Montenegro, F. \& Pacheco, R. Orientação a Objetos em C++. Ciência Moderna, 1994.

[Mul89] Mullender, S. Distributed Systems. ACM Press, pp. 3-18. 1989.

[Nas95] Nascimento, H. H. A. Sistema Gerador de Stubs. Dissertação de Mestrado. USP/ICMSC, 1995.

[Nie95] Niedermiller-Chaffins, D. Netware 3.12. Berkeley, 1995.

[Pie93] Pietrek, M. Windows Internals: the Implementation of the Windows Operating Environment. Addison-Wesley, 1993.

[Sch92] Schildt, H. Turbo C++: Guia do Usuário. Makron Books, 1992.

[Ste90] Stevens, W. R. UNIX Network Programming. Prentice-Hall, 1990.

[Str91] Stroustrup, B. The C++ Programming Language. $2^{\mathrm{a}}$ ed. Addison-Wesley, 1991.

[Sun90] Sun Microsystems. Introduction to Remote Procedure Calls. Network 
Programming, pp. 33-102, 147-167. Março, 1990.

[Tan85] Tanenbaum, A. S. \& van Renesse, R. Distributed Operating Systems. ACM Computing Surveys, vol. 17, $\mathrm{n}^{\circ}$ 4, pp. 419-69. 1985.

[Tan92] Tanenbaum, A. S. Modern Operating Systems. Prentice-Hall, 1992.

[Tan94] Tanenbaum, A. S. Redes de Computadores. Campus, 1994.

[U1193] Ullman, E. Client/Server frees Data. Byte, vol. 18, n ${ }^{\circ}$ 7, pp. 96-106. Junho, 1993.

[Wal89] Walker, B. J. \& Popek, G. J. A Transparent Environment. Byte, vol. 14, nº 7 , pp. 225-34. Julho, 1989.

[Wil87] Wilbur, S. \& Bacarisse, B. Building Distributed Systems with Remote Procedure Calls. IEE Software Engineering Journal, vol. 2, n 5 . Setembro, 1987.

[Yag97] Yager, T. Client/Server Magic. Byte, vol. 22, nº 1, pp. 53-4. Janeiro, 1997. 


\section{Bibliografia Complementar}

[Ana92] Ananda, A. L. \& Tay, B. H. A Survey of Asynchronous Remote Procedure Calls. ACM Systems Review, vol. 26, nº 2. Abril, 1992.

[Asc91] Aschmann, H. R. et al. A Remote Procedure Call Environment for Faulttolerant, Heterogeneous, Distributed Systems. IEEE Micro, pp. 16-67. Outubro, 1991.

[Bir84] Birrel, A. D. \& Nelson, B. J. Implementing Remote Procedure Calls. ACM Transactions on Computer Systems, vol. 2, n $\mathrm{n}^{\mathrm{O}}$ 1, pp. 1-14. Fevereiro, 1985.

[Dew94] Dewire, D. Application Development for Distributed Environments. McGrawHill, 1994.

[Har95] Hart, J. Client-Server Computing for Technical Professionals: Concepts and Solutions. Addison-Wesley, 1995.

[Mar93] Martin, H. et al. Windows Sockets: An Open Interface for Network Programming under Microsoft Windows. 1993.

[Nor92] Norton, P. \& Yao, P. Programando em Borland C++ para Windows. Berkeley, 1992.

[Sch97] Schildt, H. Programando em Windows 95: Segredos e Soluções. Makron Books, 1997.

[Vau94] Vaughn, L. T. Client/Server Design and Implementation. McGraw-Hill, 1994.

[Wai89] Wai, G. Distributed Processing. Byte, vol. 14, nº 7, pp. 215-24. Julho, 1989. 


\section{Apêndice A}

\section{Formalização da Linguagem de Especificação de Interfaces}

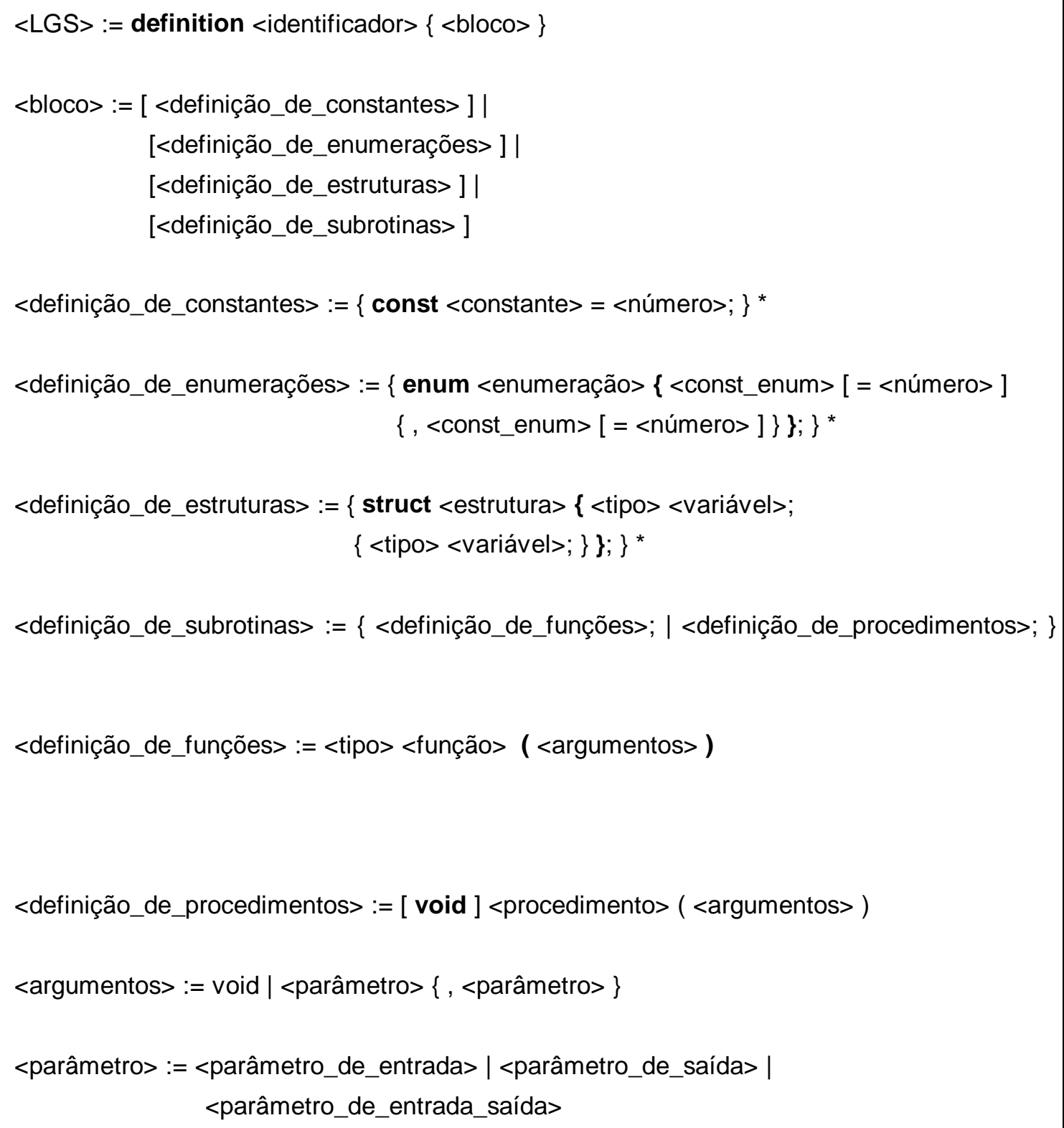




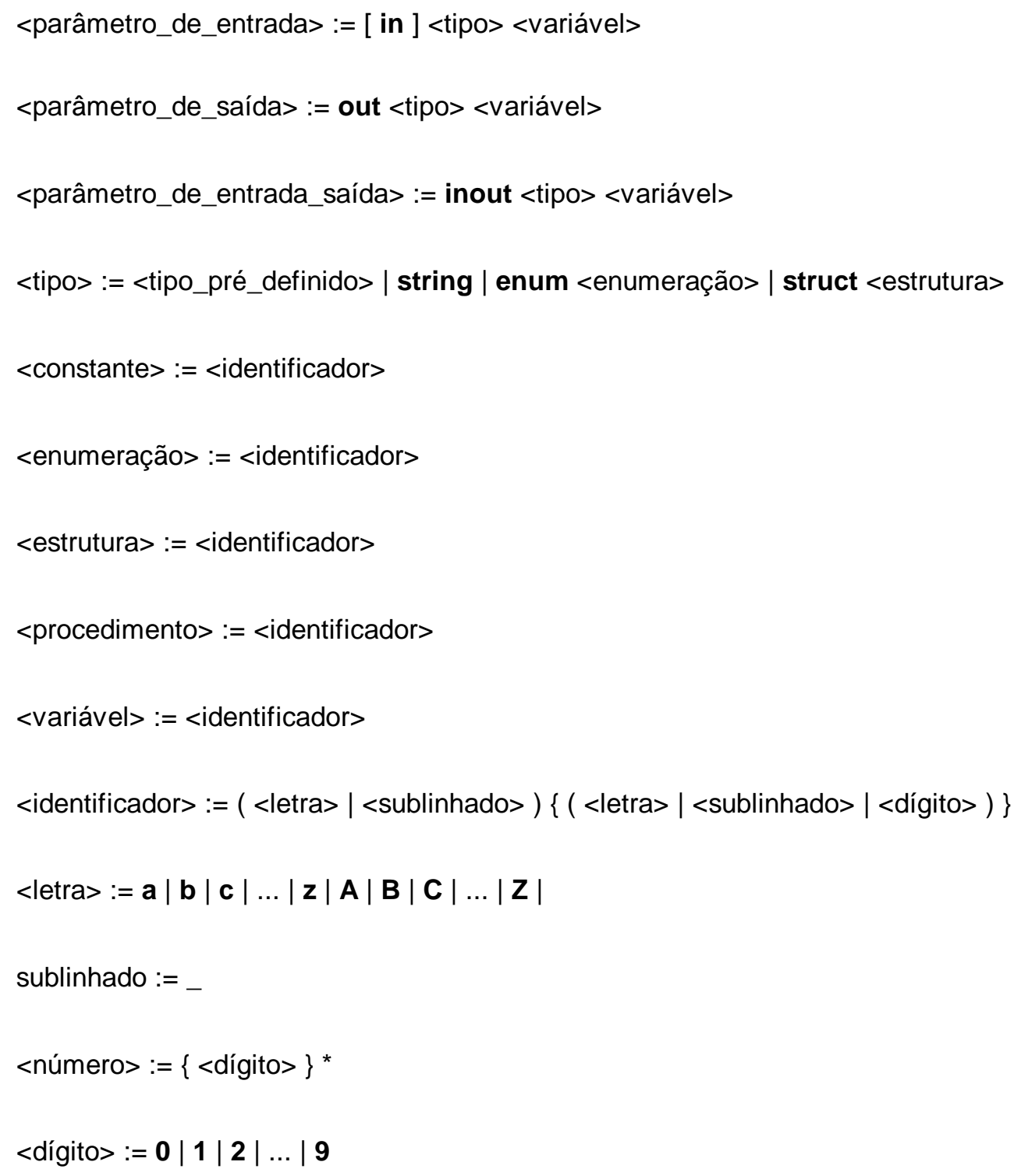




\section{Apêndice B}

\section{ORPCw95: Níveis de Classe-\&-Objeto e Estrutura}

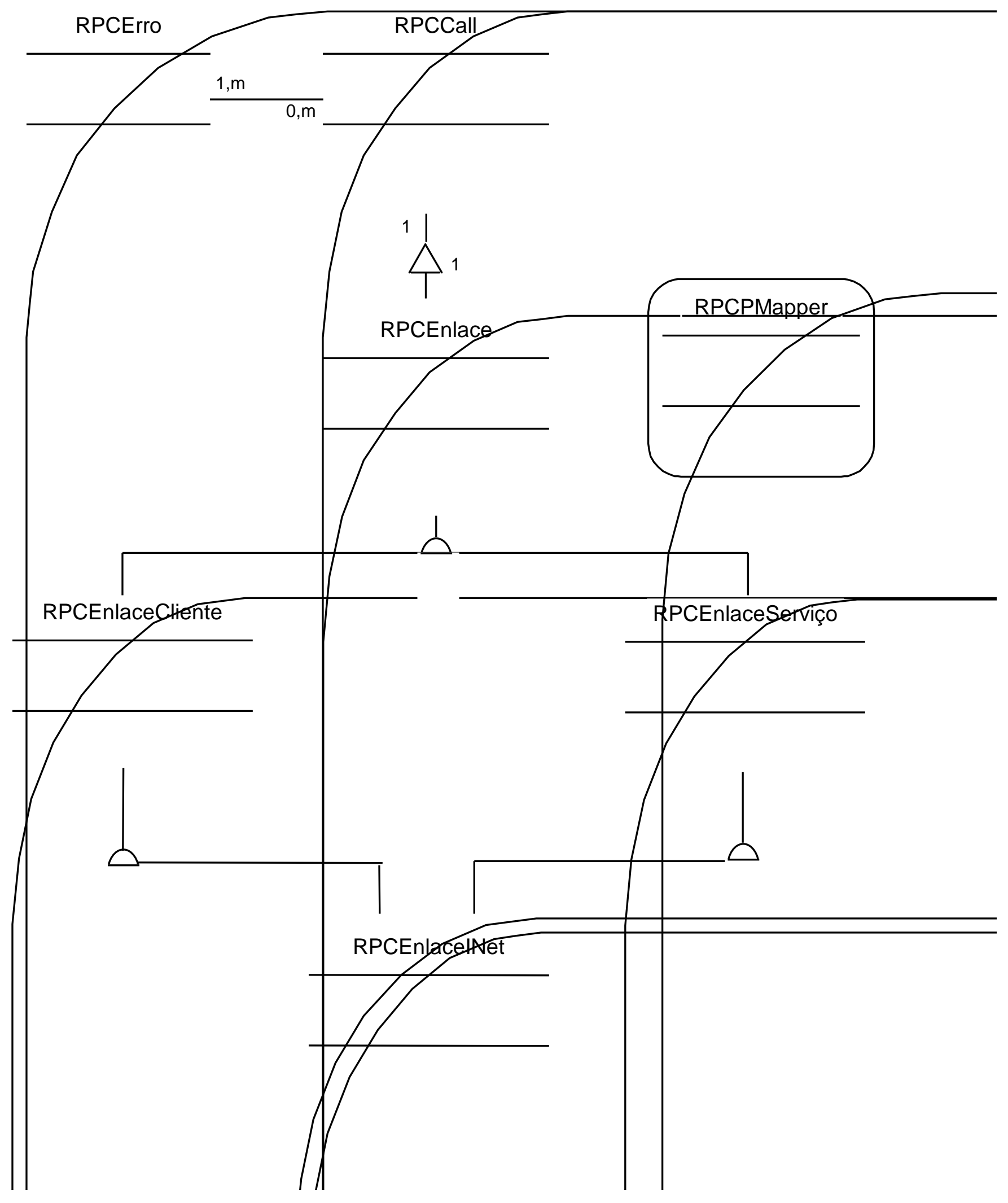




\section{Apêndice $\mathbf{C}$}

\section{ORPCw95: Códigos de Erro}

\begin{tabular}{|l|l|}
\hline Ok & Não há erro \\
\hline SemMemoria & Problemas na alocação de memória \\
\hline ErroStartup & $\begin{array}{l}\text { Erro na inicialização da biblioteca } \\
\text { WSOCK32 }\end{array}$ \\
\hline VersaoWSock & Erro na versão da biblioteca WSOCK32 \\
\hline ErroCriacaoTransp & Erro na criação do socket \\
\hline ErroBindTransp & Erro ao fazer o bind do socket \\
\hline ErroCloseTransp & Erro ao fechar o socket \\
\hline ErroSend & Problemas no envio da mensagem \\
\hline ErroRecv & Problemas na recepção da mensagem \\
\hline ErroIoctlSock & Serviço (interface) já registrado no Binder \\
\hline Errõo não registrado no Binder
\end{tabular}




\begin{tabular}{|l|l|}
\hline PMapNaoResp & O Binder (port mapper) não responde \\
\hline ConflitoInterf & O nome da interface fornecido é inválido \\
\hline ProcNaoExiste & $\begin{array}{l}\text { O procedimento solicitado não existe sob a } \\
\text { interface indicada }\end{array}$ \\
\hline ServNaoResp & O servidor não responde \\
\hline
\end{tabular}

